\title{
Lateral variations of pressure-temperature evolution in non-cylindrical orogens and 3-D subduction dynamics: the Betic-Rif Cordillera example
}

\author{
Eloïse Bessière ${ }^{1,2}$, Laurent Jolivet ${ }^{1,}$, Romain Augier ${ }^{2}$, Stéphane Scaillet ${ }^{2}$, Jacques Précigout $^{2}$, \\ José-Miguel Azañón ${ }^{3}$, Ana Crespo-Blanc ${ }^{3}$, Emmanuel Masini ${ }^{4}$ and Damien Do Couto ${ }^{1}$ \\ ${ }^{1}$ Sorbonne Université, UMR 7193 CNRS-UPMC, Institut des Sciences de la Terre de Paris, 75005 Paris, France \\ ${ }^{2}$ Université d'Orléans, UMR 7327, CNRS/INSU, BRGM, Institut des Sciences de la Terre d'Orléans, 45071 Orléans, France \\ ${ }^{3}$ University of Granada, Department of Geodynamics, Granada, Spain \\ ${ }^{4}$ M\&U sas, Saint-Egrève, France
}

Received: 24 July 2020 / Accepted: 17 February 2021

\begin{abstract}
The long-term Pressure-Temperature-time-deformation (P-T-t- $d$ ) evolution of the internal zones of orogens results from complex interactions between the subducting lithosphere, the overriding plate and the intervening asthenosphere. 2-D numerical models successfully reproduce natural $P-T-t-d$ paths, but most orogens are non-cylindrical and the situation is far more complex due to 3-D pre-orogenic inheritance and 3-D subduction dynamics. The Mediterranean orogens are intrinsically non-cylindrical. Their 3-D geometry results from the complex shape of the Eurasian and African margins before convergence and from the dynamics of slab retreat and tearing leading to strongly arcuate belts. More than many other segments, the Betic-Rif belt is archetypal of this behavior. A synthesis of the tectonometamorphic evolution of the Internal Zones, also based on recent findings by our group in the framework of the Orogen Project (Alboran domain, including the Alpujárride-Sebtide and Nevado-Filábride complexes) shows the relations in space and time between tectonic and $P-T$ evolutions. The reinterpretation of the contact between peridotite massifs and Mesozoic sediments as an extensional detachment leads to a discussion of the geodynamic setting and timing of mantle exhumation. Based on new ${ }^{40} \mathrm{Ar} /{ }^{39} \mathrm{Ar}$ ages in the Alpujárride-Sebtide complex and a discussion of published ages in the Nevado-Filábride complex, we conclude that the age of the HP-LT metamorphism is Eocene in all complexes. A first-order observation is the contrast between the wellpreserved Eocene $\mathrm{H} P$ - $\mathrm{L} T$ blueschists-facies rocks of the eastern Alpujárride-Sebtide Complex and the younger HT-L $P$ conditions reaching partial melting recorded in the Western Alpujárride. We propose a model where the large longitudinal variations in the $P-T$ evolution are mainly due to (i) differences in the timing of subduction and exhumation, (ii) the nature of the subducting lithosphere and (iii) a major change in subduction dynamics at $\sim 20 \mathrm{Ma}$ associated with a slab-tearing event. The clustering of radiometric ages obtained with different methods around 20 Ma results from a regional exhumation episode coeval with slab tearing, westward migration of the trench, back-arc extension and thrusting of the whole orogen onto the African and Iberian margins.
\end{abstract}

Keywords: Betic Cordillera / Rif / subduction dynamics / slab retreat / high pressure metamorphism / anatexy / exhumation / sub-continental peridotites

Résumé - Variations latérales de l'évolution pression-température dans les orogènes non cylindriques et dynamique 3-D de subduction, le cas de l'orogène bético-rifain. L'évolution pressure-température-temps-déformation (P-T-t-d) des zones internes des orogènes résulte d'interactions complexes entre la lithosphère subduite, la plaque chevauchante et le manteau asthénosphérique. Les modèles numériques 2-D reproduisent assez bien les chemins P-T-t-d, mais les orogènes sont rarement cylindriques. L'héritage de la géométrie 3-D pré-orogénique et la dynamique 3-D de subduction rendent en effet la situation souvent plus complexe. Les orogènes méditerranéens sont intrinsèquement non cylindriques

*Corresponding author: laurent.jolivet@sorbonne-universite.fr 
parce que la géométrie des marges africaines et eurasiennes avant la collision était également non cylindrique et parce que les panneaux lithosphériques en subduction ont changé de forme pendant le recul des fosses. Ils sont devenus plus étroits à la suite d'une série déchirures qui ont conduit à la formation d'arcs fortement pincés. L'orogène bético-rifain est emblématique de ce comportement, plus que tout autre segment. Une synthèse de l'évolution tectono-métamorphique des zones internes de cet orogène, en partie basée sur des observations récentes faites par notre groupe dans le cadre du programme Orogen, dans le Domaine d'Alboran (incluant les nappes des Alpujárride-Sebtide et des Nevado-Filábride) montre les relations dans l'espace et le temps entre la déformation et l'évolution P-T. Une réinterprétation du contact entre les massifs péridotitiques et les sédiments carbonatés mésozoïques dans la région de Ronda conduit à une discussion sur le calendrier et le mécanisme de l'exhumation du manteau. Nous montrons que l'âge du métamorphisme de subduction est partout éocène en nous appuyant sur de nouveaux âges ${ }^{40} \mathrm{Ar} /{ }^{39} \mathrm{Ar}$ dans les Alpujárride-Sebtide et sur une discussion des âges publiés dans les Nevado-Filábride. Une observation de premier ordre est le contraste marqué entre les unités à paragenèses de HP-BT bien préservées des Alpujárride-Sebtide orientales et centrales et les unités affectées par un métamorphisme plus jeune de HTLP atteignant les conditions de l'anatexie dans l'ouest des Alpujárride-Sebtide. Nous proposons un modèle où les variations longitudinales de la forme des conditions P-T résultent principalement de : (i) différents calendriers de la subduction et de l'exhumation, (ii) la nature de la lithosphère subduite et (iii) un changement majeur de la dynamique de subduction il y a environ $20 \mathrm{Ma}$, associé à une déchirure du panneau plongeant. Le regroupement des âges radiométriques obtenus par différentes méthodes autour de $20 \mathrm{Ma}$ dans toute la région résulte d'un épisode régional d'exhumation associé à la déchirure du panneau plongeant, la migration de la fosse vers l'ouest, l'extension arrière-arc et le chevauchement de l'ensemble de l'orogène sur les marges africaine et ibérique.

Mots clés : cordillère bétique / Rif / dynamique de subduction / retrait du slab / métamorphisme de haute pression / anatexie / exhumation / péridotites sous-continentales

\section{Introduction}

Cylindrical orogens, whose evolution can be fully described along 2-D sections, almost never exist. The firstorder features of the Himalayas can be represented in 2-D (Gansser, 1981; Searle et al., 1987; Guillot et al., 2008) but it would not pay tribute to the peculiar situation of the east and west syntaxes where the geometry of the interacting lithospheres becomes complex in 3-D (Burg et al., 1997). The evolution of the Andes is also very different along strike, whether the slab underneath is flat or steep (Oncken et al., 2006). Such a 3D non-cylindricity is also well imaged by the present-day North-Caribbean region where the Cuba Upper Cretaceous-Paleogene high-pressure-belt is laterally branching with the Hispaniola Oligocene transpressional tear-zone of the present-day Lesser Antilles subduction (e.g. Pindell et al., 2006). This aspect is even more crucial in small orogens like the Mediterranean ones showing tight curvatures such as the Betic-Rif arc, the Alps and the Apennines (Fig. 1), subduction polarity changes such as between the Alps and the Apennines or along-strike evolution from a mountain belt to a collapsed and extended segment such as between the Hellenides and the Aegean Sea, due to interactions of subducted slabs at depth (Malinverno and Ryan, 1986; Wortel and Spakman, 2000; Faccenna et al., 2004; Spakman and Wortel, 2004; Jolivet et al., 2013; Platt et al., 2013; Malusa et al., 2015). These complex 3-D interactions between crustal deformation and slab dynamics involve variable pressure-temperature $(P-T)$ conditions in metamorphic units along strike. The record of exhumed metamorphic units from the internal zones of Alpine orogens is thus key for understanding these thermal and mechanical interactions (Jolivet et al., 2010; Malusa et al., 2015). The Alps, the Hellenides-Taurides or the Betic-Rif orogens are among the best studied examples in terms of $P-T$ - time evolution because of a long history of international research and excellent outcropping conditions. It has been shown that the shape of $P-T$ paths highlights considerable variations along and across strike in these orogens and that these variations can be correlated with changes in the nature and thickness of the subducting lithosphere, the kinematic boundary conditions and/or subduction geometry and velocity in space and time (Selverstone and Spear, 1985; Davy and Gillet, 1986; Bousquet et al., 1997, 2008; Jolivet et al., 2003, 2010; Yamato et al., 2007). The advent of high-resolution 3-D numerical modeling allows testing the effects of these firstorder parameters, but conceptual models should be first proposed based on field observations and laboratory-based assessment of $P$-T-time paths, among other types of data.

The tight Betic-Rif arc (Figs. 1-3) is a natural proto-type where 3-D subduction dynamics imparts a strong control on crustal-scale tectonometamorphic evolution (Azañón et al., 1994; Azañón and Goffé, 1997; Jolivet et al., 2003; Faccenna et al., 2004; Spakman and Wortel, 2004; Platt et al., 2013). The present-day structure of the two orogenic segments, the Betic Cordillera in Spain and the Rif in Morocco, facing the Alboran Sea, has been described in detail after a century of research (de Orueta, 1917; Blumenthal, 1927; Egeler and Simon, 1969; Andrieux et al., 1971; Kornprobst, 1974; Loomis, 1975; Didon and García-Dueñas, 1976; Frizon de Lamotte et al., 1991; García-Dueñas et al., 1992; Augier et al., 2005a, 2005b; Michard et al., 2006; Chalouan et al., 2008; Platt et al., 2013; Booth-Rea et al., 2015; Williams and Platt, 2018; GómezPugnaire et al., 2019) and yet some first-order questions remain pending, such as the emplacement mechanism of subcontinental peridotite massifs, the timing of development and exhumation of metamorphic complexes (MCC) during synand post-orogenic extension or the formation of intramountain basins in a rather short period in the Oligocene 


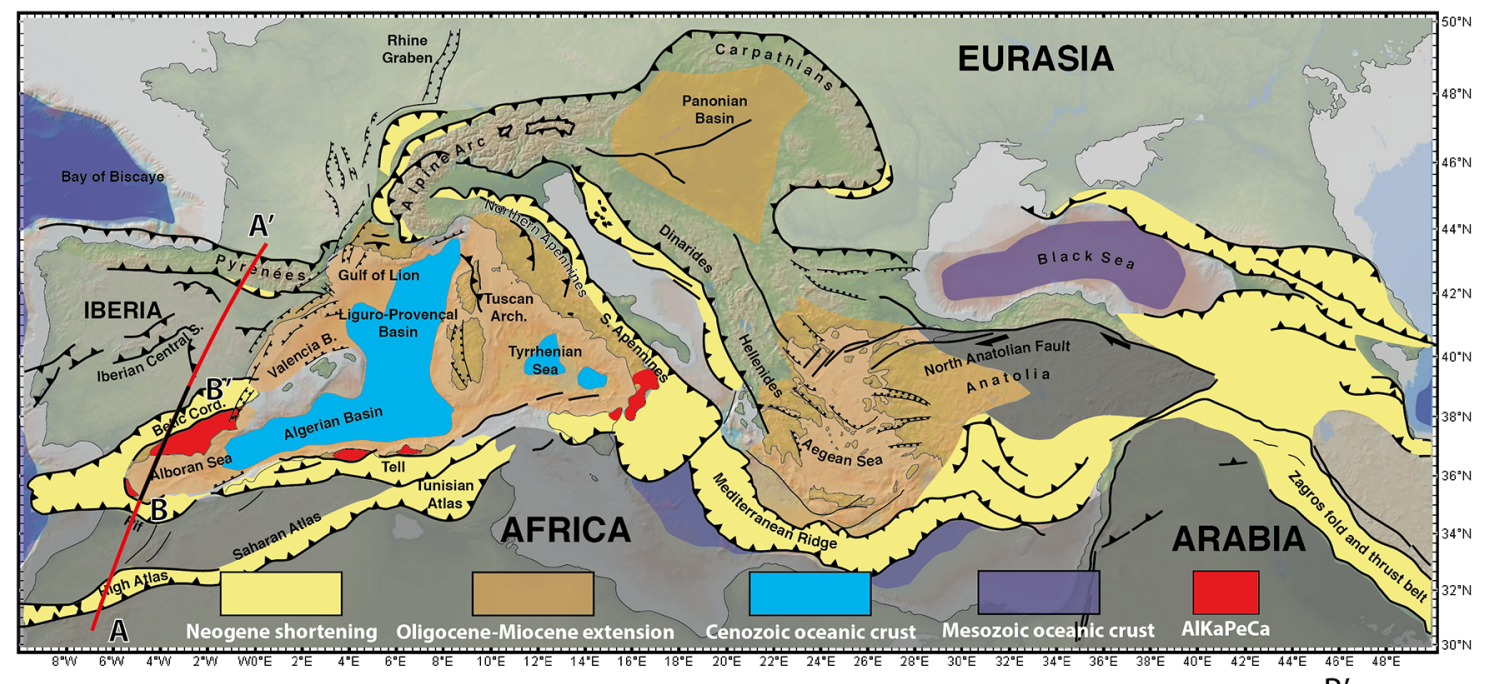

B

$B^{\prime}$
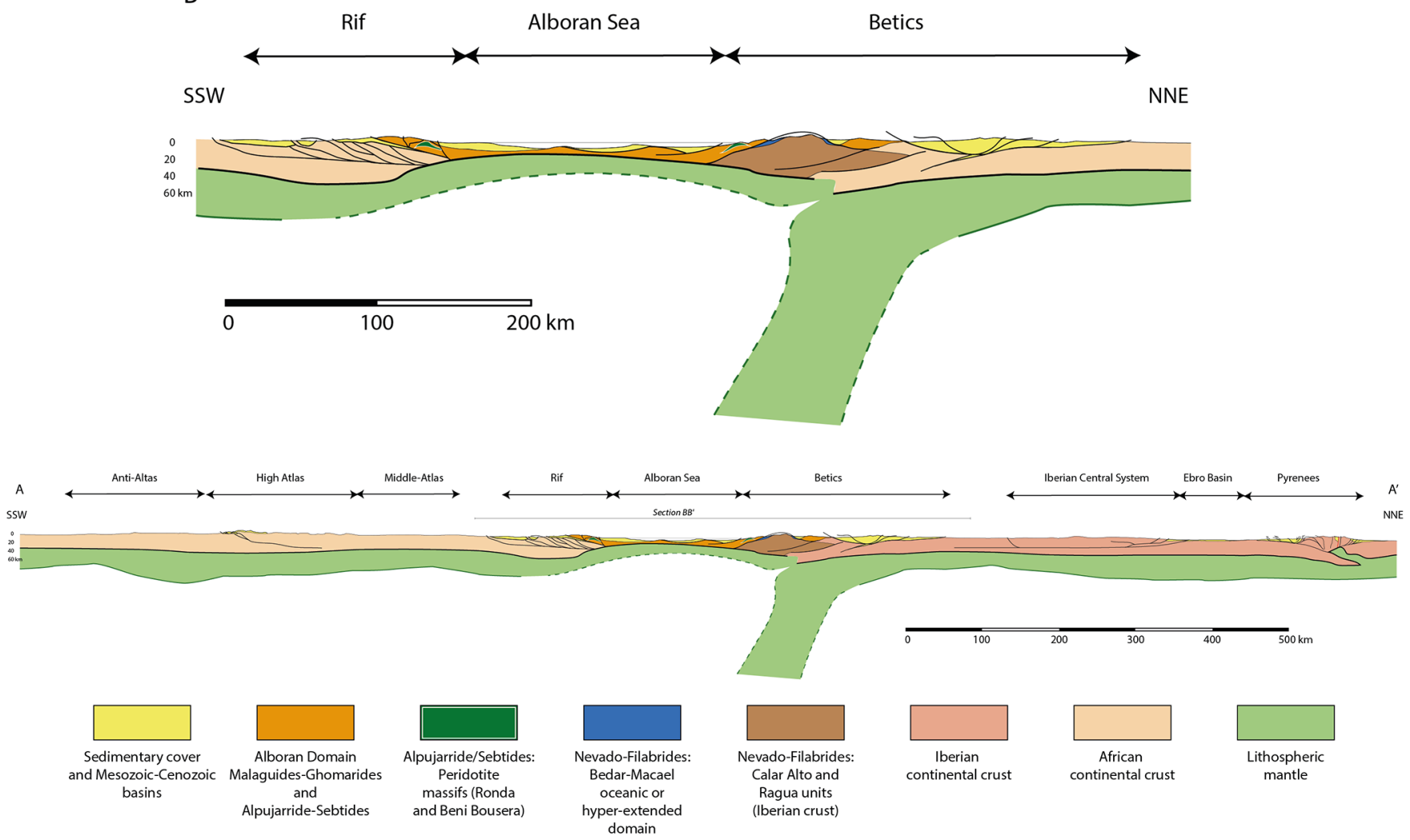

Fig. 1. Tectonic map of the Mediterranean region showing the main Alpine features, mountain belts and back-arc basins. A: Lithospheric-scale cross section from the Atlas to the Aquitaine Basin across the Alboran region and the Pyrenees after Diaz et al. (2016), de Lis Mancilla et al. (2018), Chevrot et al. (2018), Teixell et al. (2018), Frizon de Lamotte et al. (2000) and Quintana et al. (2015). B: Zoom of the Alboran Sea region.

and Miocene. Large longitudinal displacements, strong paleomagnetic rotations, coeval thrusting in the External Zones and extension in the Internal Zones are ingredients of a complex 3-D evolution of the piece of lithosphere deforming between the converging Africa and Eurasian plates in the western Mediterranean (Frizon de Lamotte et al., 1991; Lonergan and White, 1997; Jolivet et al., 2008; Platt et al., 2013; van Hinsbergen et al., 2014; Crespo-Blanc et al., 2016).
Within the Betic Cordillera and the Rif, the AlpujárrideSebtide and Nevado-Filábride Complexes (Figs. 2-4), forming the metamorphic core of the orogen (also known as the Alboran Domain), have recorded these complex interactions at depth and their evolution can be analyzed using the tools of structural geology, metamorphic geology and radiometric dating. Different models have been proposed so far, involving the deep lithosphere, either through delamination, convective 


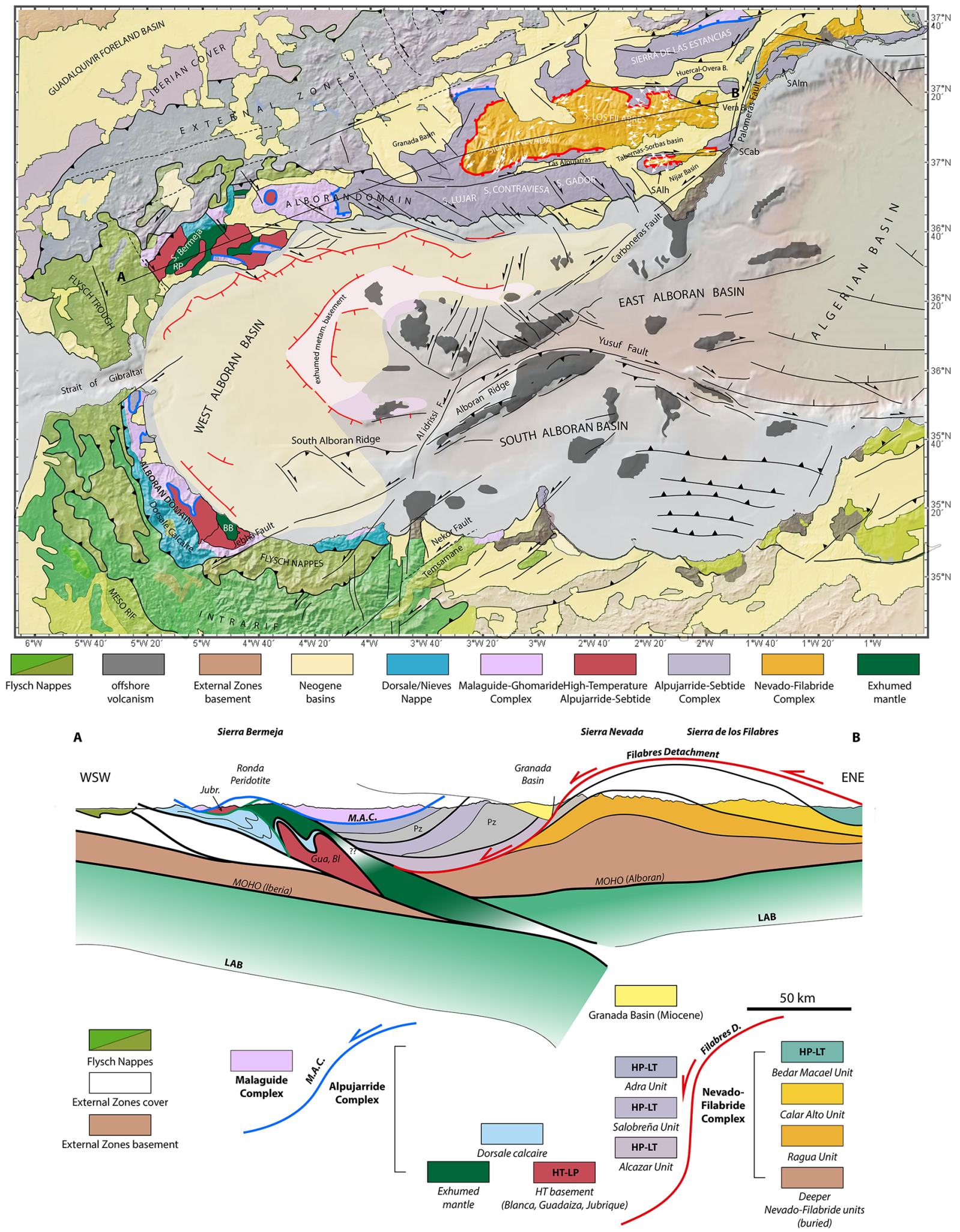

Fig. 2. Tectonic map of the Alboran Sea, the Betic Cordilleras and the Rif, compiled from Comas et al. (1999), d'Acremont et al. (2020) and Chalouan et al. (2008). Lithospheric-scale E-W section through the Betic Cordillera. Deep crustal and lithospheric structures after de Lis Mancilla et al. (2018) and Gueydan et al. (2019). The Ronda peridotite massif is sandwiched between the Guadaiza and Blanca units underneath and the Jubrique Unit above. Abbreviations: Bl: Blanca, BB: Beni Bousera, Gua: Guadaiza, Jubr: Jubrique, LAB: lithosphere-Asthenosphere boundary, M.A.C.: Malaguide-Alpujárride Contact detachment, Pz: Paleozoic, RP: Ronda Peridotite. 


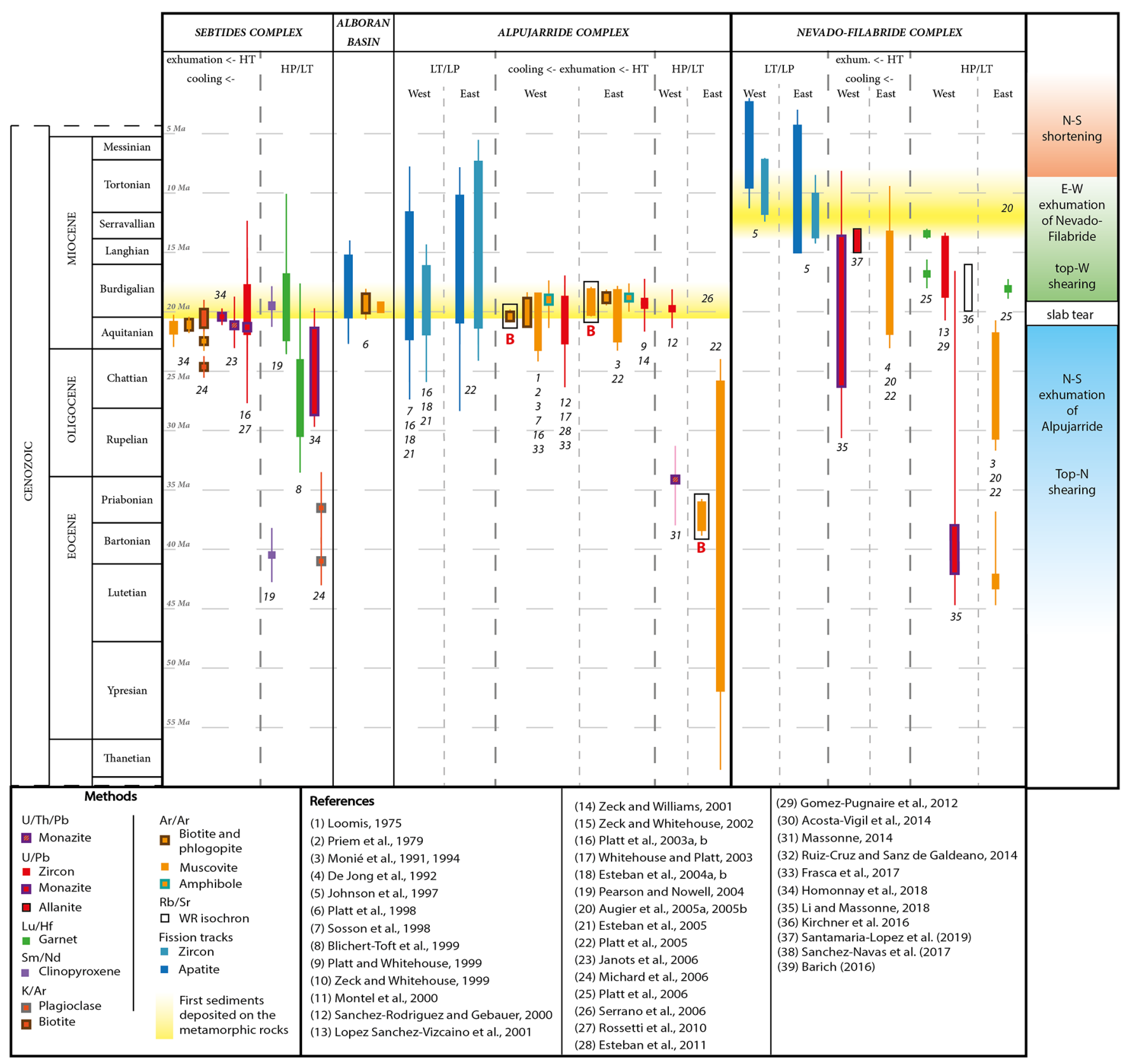

Fig. 3. Compilation of available radiometric ages in the Rif and Betic internal zones (Loomis, 1975; Priem et al., 1979; Monié et al., 1991, 1994; De Jong et al., 1992; Johnson et al., 1997; Platt et al., 1998, 2003b, 2003c, 2005, 2006; Sosson et al., 1998; Blichert-Toft et al., 1999; Platt and Whitehouse, 1999; Zeck and Whitehouse, 1999, 2002; Montel et al., 2000; Sánchez-Rodríguez and Gebauer, 2000; López Sánchez-Vizcaíno et al., 2001; Zeck and Williams, 2001; Platt et al., 2003c; Whitehouse and Platt, 2003; Esteban et al., 2004a, 2004b, 2005, 2011; Pearson and Nowell, 2004; Augier et al., 2005a, 2005b; Janots et al., 2006; Michard et al., 2006; Serrano et al., 2006; Rossetti et al., 2010; Gómez-Pugnaire et al., 2012; Acosta-Vigil et al., 2014; Massonne, 2014; Ruiz-Cruz and Sanz de Galdeano, 2014; Barich, 2016; Kirchner et al., 2016; Frasca et al., 2017; Sánchez-Navas et al., 2017; Homonnay et al., 2018; Li and Massonne, 2018; Santamaria-Lopez et al., 2019). Right column shows an interpretation of the main tectonic and geodynamic events recorded in the orogen. Samples marked B refer to those dated by Bessière (2019).

removal or slab retreat (Platt and Vissers, 1989; García-Dueñas et al., 1992; Lonergan and White, 1997; Chalouan et al., 2001, 2008; Michard et al., 2002; Faccenna et al., 2004; Jolivet et al., 2006; Booth-Rea et al., 2007; Mazzoli and MartinAlgarra, 2011; van Hinsbergen et al., 2014; de Lis Mancilla et al., 2015; Williams and Platt, 2018). Recent tomographic investigations have shown the complexity of slab geometry beneath the Gibraltar arc (Spakman and Wortel, 2004; Bezada et al., 2013; Palomeras et al., 2017) and thus the complexity of its evolution. Different models of the geometry of slabs were proposed, associated with different finite longitudinal displacements of the Alboran Domain along the southeastern 
margin of Iberia and different slab configurations (Lonergan and White, 1997; Rosenbaum et al., 2002; Jolivet et al., 2003; Vergés and Fernàndez, 2012; Chertova et al., 2014; van Hinsbergen et al., 2014; Romagny et al., 2020).

In this paper, based on new investigations in the Alpujárride Complex, we discuss the 3-D evolution of the Betic-Rif orogen and propose a conceptual model explaining the lateral changes of $P-T$ conditions and timing of exhumation. We focus on the differences between the western and eastern-central Betics in terms of $P-T$ evolution and on the significance of the clustering of radiometric ages around $20 \mathrm{Ma}$ despite a large variety of methods. We propose a model where (1) the pre-orogenic configuration of the Iberian and African margins and of the transition to the oceanic crust of the Maghrebian Tethys explains the contrast between colder $P-T$ paths in the center and east associated with a better preservation of the $\mathrm{H} P$-L $T$ parageneses or isotopic records and the warmer P-T paths in the western Alpujárride-Sebtide complex and (2) the $20 \mathrm{Ma}$ cluster of ages is due to a drastic regional-scale exhumation event of the whole Alboran Domain when the slab was torn and started its fast westward retreat, associated with back-arc extension in the Alboran Sea and overthrusting on the Alboran Domain on the passive margins of Africa and Iberia.

\section{Tectonic and geodynamic setting}

We first shortly review the geodynamic context of the Betic Cordillera and the Rif in order to extract a few major questions that remain pending. The Betic Cordillera and the Rif are the two arms of the Gibraltar arc, a tightly curved Mediterranean orogen partly formed during the westward retreat of the lithospheric slab hanging underneath (García-Dueñas and Navarro-Vila, 1976; Platt, 1986; Goffé et al., 1989; Comas et al., 1992, 1999; García-Dueñas et al., 1992; Vissers et al., 1995; Feinberg et al., 1996; Lonergan and White, 1997; Chalouan et al., 2001; Michard et al., 2002; Platt et al., 2003a, 2003b, 2013; Jolivet et al., 2003, 2006; Crespo-Blanc et al., 2016; Martínez-García et al., 2017). It belongs to a series of orogens (Fig. 1) formed within the wide and diffuse convergence zone of the African plate toward Eurasian plate, including the Atlas mountains, the Iberian Central System, the Iberian Range and the Pyrenees (Vergés and Sabat, 1999; Frizon de Lamotte et al., 2000, 2004, 2008; Mouthereau et al., 2014; Booth-Rea et al., 2015; Teixell et al., 2018; Dielforder et al., 2019). Crustal thickening started in the Eocene (Lonergan, 1993; Lonergan and White, 1997) or maybe earlier in the Late Cretaceous (Daudet et al., 2020) within the so-called Alboran Domain (Andrieux et al., 1971; Balanyá and García-Dueñas, 1987; Platt et al., 2013; Casciello et al., 2015), assumed as a part of the AlKaPeCa block (Fig. 1), a postulated continental block whose remnants are found dispersed around the Alboran Sea in Spain and Morocco, in the Kabylies in Algeria, in the Peloritani Mountains in Sicily and in Calabria (Bouillin et al., 1986). Extension started in the Oligocene as in all the Mediterranean back-arc basins (Comas et al., 1999; Platt and Whitehouse, 1999; Jolivet and Faccenna, 2000; Platt et al., 2003c). The Internal Zones of the Betic-Rif orogen (Fig. 2) were subjected to intense crustal thinning between $\sim 30$ and $8 \mathrm{Ma}$. Before $8 \mathrm{Ma}$, the predominant regime was extensional in the Alboran Sea that evolved as a back-arc basin, and compressional all around (Platt and Vissers, 1989; Bourgois et al., 1992; García-Dueñas et al., 1992; MartínezMartínez et al., 1997, 2002, 2004; Comas et al., 1992, 1999; Martinez-Martinez and Azañón, 2002; Booth-Rea et al., 2007; Platt et al., 2013). Since about $8 \mathrm{Ma}$, the main regime is a slow $\mathrm{N}-\mathrm{S}$ shortening associated with perpendicular extension giving rise to long wavelength folding in the Betics, recent and active normal faulting at the western end of the Sierra Nevada and strike-slip and reverse faults offshore in the Alboran Sea and along the eastern coast of Spain (De Smet, 1984; De Larouzière et al., 1988; Montenat and Ott d'Estevou, 1999; Meijninger and Vissers, 2006; Pedrera et al., 2010; Augier et al., 2013; Martínez-García et al., 2013; Do Couto et al., 2016; Janowski et al., 2017).

A major kinematic change occurred some $20 \mathrm{Ma}$ ago (Crespo-Blanc et al., 1994; Azañón et al., 1997; Jolivet et al., 2006, 2008). The direction of brittle and ductile extension was mainly N-S before and E-W after $20 \mathrm{Ma}$. This major change was probably a consequence of a slab tear episode that triggered a change in the direction of retreat from southward to westward (Faccenna et al., 2004; Spakman and Wortel, 2004; Jolivet et al., 2006). Before $28 \mathrm{Ma}$, the Alboran Domain has recorded evidence of $\mathrm{H} P$-LT metamorphism (Goffé et al., 1989; Lonergan, 1993; Bouybaouene et al., 1995; Michard et al., 1997, 2006; Augier et al., 2005a, 2005b; Platt et al., 2005; Li and Massonne, 2018; Homonnay et al., 2018), with typical high-pressure and low-temperature (HP-LT) metamorphic conditions recorded in the two deepest metamorphic complexes, the Alpujárride-Sebtides and the Nevado-Filábride Complexes (Gómez-Pugnaire and Fernandez-Soler, 1987; Goffé et al., 1989; Azañón and Goffé, 1997; Puga et al., 2000; Booth-Rea et al., 2002; Augier et al., 2005a, 2005b; Negro et al., 2005; Platt et al., 2006; Santamaria-Lopez et al., 2019; Gómez-Pugnaire et al., 2019).

\subsection{Slab retreat, back-arc basin and frontal accretion, a typical Mediterranean scheme}

Slab retreat during the Late Oligocene and the Miocene has shaped the Alboran Sea and led to the sharp bend we see today from the Betics to the Rif. The most obvious structures in the Internal Zones of the two branches of the orogen relate to the episode of slab retreat and associated E-W extension. Then, after $\sim 8 \mathrm{Ma}$, extension was replaced by a dominant $\mathrm{N}-\mathrm{S}$ contractional regime. This recent $\mathrm{N}-\mathrm{S}$ compression led to modest finite shortening rates of a few $\mathrm{mm} / \mathrm{yr}$ (Borque et al., 2019; Valetti et al., 2019) and has thus not strongly modified the crustal thickness, preserving the main extensional contacts in the internal zones of the Betics and the Rif. The Internal Zones were then affected by E-W directed very large-scale folds associated with the relieves of Sierra Los Filabres, Sierra Nevada or Sierra Contraviesa (Fig. 2). The E-W OligoMiocene extensional episode is marked by the formation of several metamorphic core complexes (MCC) before and after 20 Ma (Platt, 1986; Platt and Vissers, 1989; García-Dueñas et al., 1992; Lonergan and Platt, 1995; Balanyá et al., 1997; Martínez-Martínez et al., 1997; Platt et al., 2003a, 2013) (Figs. 3 and 4). Two major detachment systems have been described between the main metamorphic complexes (Figs. 2 

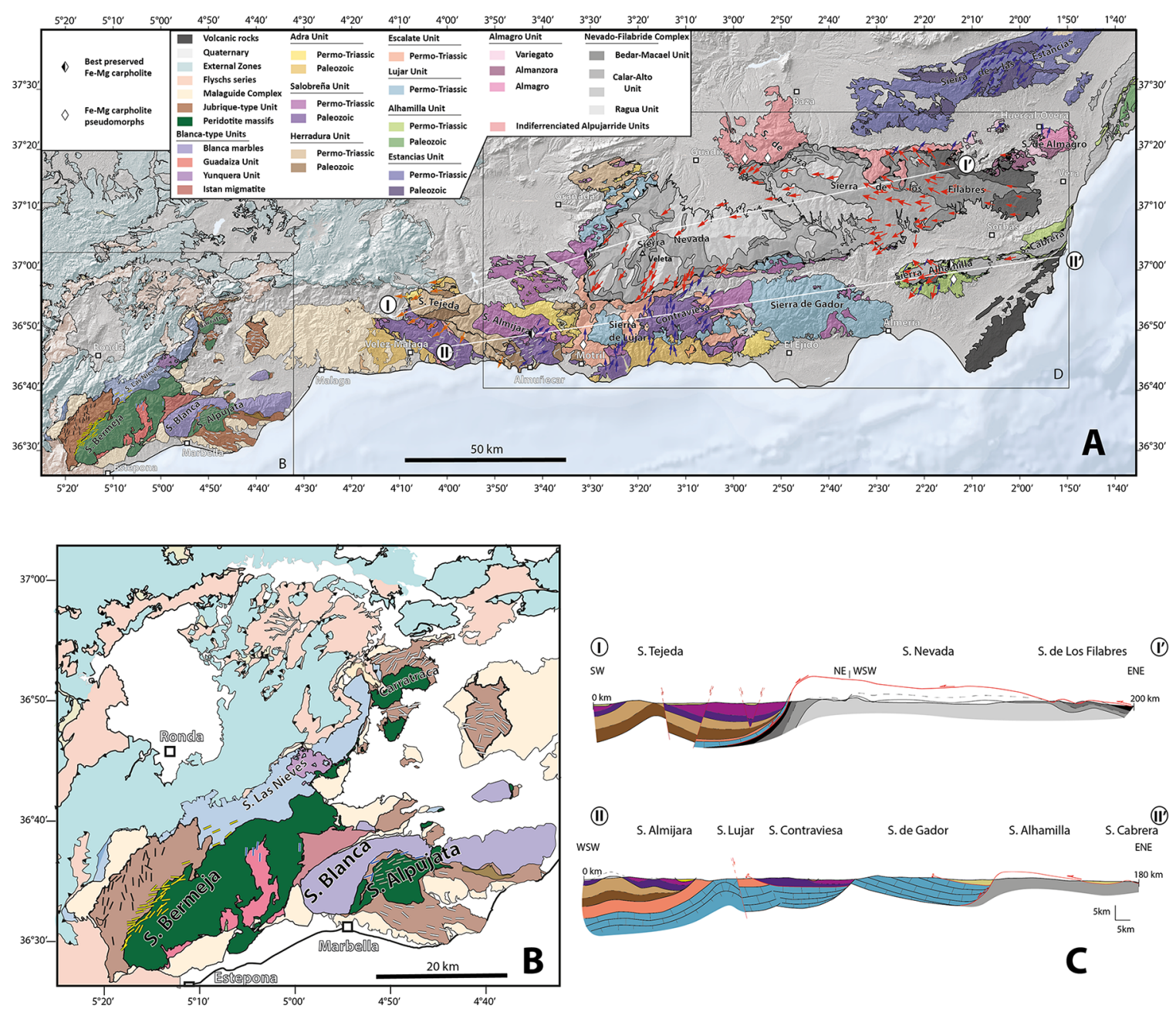

C

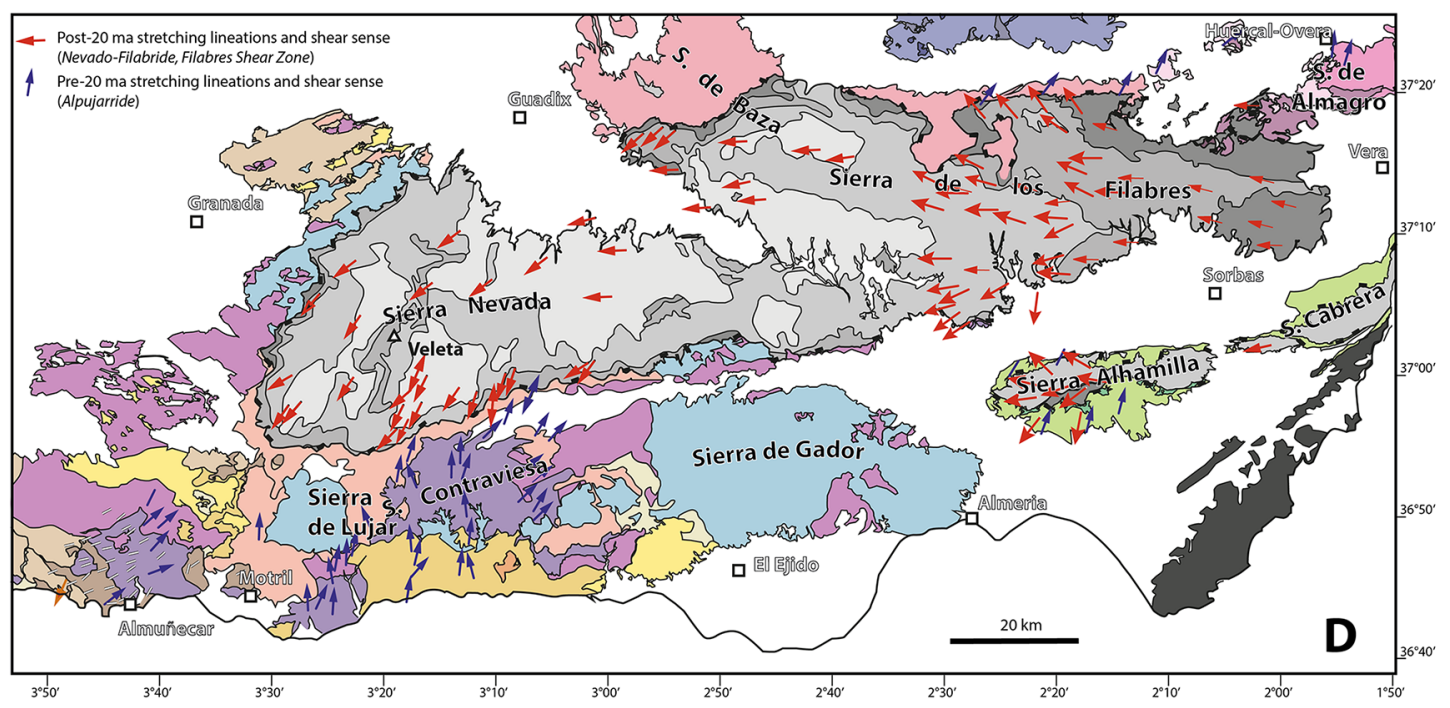

Fig. 4. Geology of the Internal Zones of the Betic Cordilleras. A: tectonic map showing the different units of the Alpujárride and NevadoFilábride complexes. White lines are the cross-sections of Figure 4C. The preservation of Fe-Mg-carpholite is shown. B: Detailed map of the western Alpujárride complex with the directions of stretching lineations from Williams and Platt (2018) and Bessière (2019). C: Two E-W crosssections. D: Detailed map of the central and eastern Alpujárride with lineations and sense of shear after Jabaloy et al. (1993), Augier et al. (2005b, 2013), Jolivet et al. (2008). 
and 4). The Malaguide-Alpujárride Contact (MAC) was mainly active before $20 \mathrm{Ma}$ with a top-to-the north or northeast kinematics, and the Mecina and the Filabres Shear Zones after $20 \mathrm{Ma}$ with a top-to-the west or southwest kinematics (Jabaloy et al., 1993; Crespo-Blanc et al., 1994; Crespo-Blanc, 1995; Martínez-Martínez et al., 2002; Jolivet et al., 2006, 2008).

Extension within the Alboran Domain was coeval with thrusting at the periphery of the orogen (Platt and Vissers, 1989), thrusting within the External Zones forming typical fold-and-thrust belts and overthrusting of the Alboran Domain on top of the African and Iberian deforming continental margins (Lonergan and White, 1997; Frizon de Lamotte et al., 2004; Crespo-Blanc and Frizon de Lamotte, 2006; Platt et al., 2013). This behavior is typical of the peri-Mediterranean orogens with the association of a set of back-arc basins established on the collapsed internal zones and a fold and thrust belt in the outer zones (Malinverno and Ryan, 1986; Jolivet et al., 2003, 2008; Chalouan et al., 2008). The Tyrrhenian Sea is associated with the Apennines and the Aegean Sea with the Hellenides and the Mediterranean Ridge accretionary wedge in a similar way (Fig. 1). The tight curvature of the Betic-Rif arc can be compared to the bending of the Hellenic and Calabrian arcs, two examples resulting from the retreat of slab portions (Faccenna et al., 2004; Spakman and Wortel, 2004). The Betic-Rif arc is the tightest of all three arcs (Platt et al., 2003a; Faccenna et al., 2004) because the space available for slab roll-back and the width of the oceanic domain to be subducted between Africa and Iberia are narrower. The extensional deformation observed in the internal zones of the Betics during the Miocene is a consequence of the westward motion of the Alboran block migrating above the retreating slab. The initial position of the Alboran Domain (and of the whole AlKaPeCa block) is debatable, but several hundreds of kilometers of relative displacement are acknowledged in all recent studies (van Hinsbergen et al., 2014; Leprêtre et al., 2018; Romagny et al., 2020).

The last slab retreat episode started around $20 \mathrm{Ma}$, which is also precisely the age of most radiometric ages available in the Internal Zones of the Betics and the Rif(Fig. 3). This clustering of ages has been classically interpreted as witnessing a hightemperature (HT) overprint, coeval with tearing of the slab and fast back-arc extension (Platt et al., 2013, for a review). The observation of similar Early Miocene ages within metamorphic units free of any significant thermal overprint (Bessière, 2019) however raises the question of the significance of this episode, coeval with the overthrusting of the Internal Zones on top of the External Zones. This is one of the main questions addressed in the present paper.

\subsection{Alpine subduction and collision}

The evolution of the belt during the Alpine orogenic construction is not well established and the age of the HP-LT metamorphic conditions is still debated (Augier et al., 2005b; Platt et al., 2005, 2006; Gómez-Pugnaire et al., 2019). The HPLT parageneses found in the Alpujárride-Sebtide and NevadoFilábride Complexes (Azañón and Goffé, 1997; Puga et al., 2000; Booth-Rea et al., 2002; Augier et al., 2005b; Massonne, 2014; Li and Massonne, 2018) can be interpreted as evidence for subduction of these continental units. The highest pressure is recorded in the uppermost unit of the Nevado-Filábride Complex with eclogite-facies units (Gómez-Pugnaire and Fernandez-Soler, 1987; Puga et al., 2000; Li and Massonne, 2018; Gómez-Pugnaire et al., 2019; Santamaria-Lopez et al., 2019) and low- $T$ blueschists with preserved Fe-Mg-carpholite, aragonite and saliotite in the Alpujárride Complex (Goffé et al., 1989; Azañón and Goffé, 1997; Booth-Rea et al., 2002). Available radiometric ages span a rather long period running from the Eocene to the Early Miocene in both complexes (Fig. 3) (see more details below), but there is no consensus on the relative timing of metamorphic events in the two domains. In particular, the age of the H $P$-L $T$ metamorphism could be diachronous, i.e. younger in the Nevado-Filábride Complex where Middle Miocene ages have been proposed (López Sánchez-Vizcaíno et al., 2001; Platt et al., 2006). A debated Eocene age for the first HP-LT metamorphism has been proposed for both complexes (Monié et al., 1991; Augier et al., 2005a; Platt et al., 2005; Li and Massonne, 2018), which is in line with the observation of an unconformity of Oligocene conglomerates on top of deformed Eocene deposits in the Sierra Espuña, a part of the Malaguide Complex of the Betics (Lonergan, 1993; Lonergan and Platt, 1995). This Eocene episode is recorded only within the Alboran Domain while the formation of the external fold-and-thrust belt at the expense of the sedimentary cover of Iberia is essentially Miocene (Platt et al., 2013; Crespo-Blanc et al., 2016). This difference in the timing of deformation signs the large distance between Alboran and the southern margin of Iberia in the Eocene. The southern margin of Iberia was affected by shortening only after the Alboran domain had travelled westward following slab retreat (van Hinsbergen et al., 2014, 2019; Romagny et al., 2020). Recent investigations in the Flysch complex sandwiched between the Internal and External Zones however suggest an earlier compressional episode, as early as the Late Cretaceous, in an intermediate area between the Alboran Domain and the Iberian margin, coeval with the initiation of convergence between Africa and Eurasia (Daudet et al., 2020).

\subsection{Mantle exhumation}

One of the particular features of the Betic-Rif orogen is the presence of large sub-continental mantle exposures, the Ronda peridotite massif in the Betics and Beni Bousera peridotite massif in the Rif, associated with smaller massifs (Carratraca, Sierra Alpujata, Ceuta) (de Orueta, 1917; Blumenthal, 1927; Kornprobst, 1976; Obata, 1980; Reuber et al., 1982; Platt et al., 2003b; Frasca et al., 2017; Homonnay et al., 2018) (Figs. 2 and 4). Several models were proposed for the emplacement of these massifs, with drastically different mechanisms, from mantle diapirism (Loomis, 1975; Weijermars et al., 1985; Zeck et al., 1990; Weijermars, 1991; Tubía et al., 2004), inversion of a back-arc basin (Booth-Rea et al., 2005; Gueydan et al., 2019), extrusion of a mantle wedge (Tubía and Cuevas, 1986; Vauchez and Nicolas, 1991; Tubía et al., 1997; Mazzoli and Martin-Algarra, 2011; Mazzoli et al., 2013), collapse of the orogen and/or hyper-extension (Kornprobst and Vielzeuf, 1984; Doblas and Oyarzun, 1989; van der Wal and Vissers, 1996; Platt et al., 2003a, 2003b; Hidas et al., 2013; Précigout et al., 2013; Bessière, 2019; Rossetti et al., 2020) or a combination of these mechanisms (Reuber et al., 1982; 
Garrido et al., 2011). The present-day situation of the Ronda peridotite massif is described as a thrust package also including crustal units, resting on top of the External Zones and the timing of this late thrusting episode is well constrained in the early Miocene on stratigraphic grounds (Bourgois et al., 1972; Serrano et al., 2006; Gueydan et al., 2019). However, the exhumation process from mantle depth, as well the timing of exhumation, are still debated (Kornprobst et al., 1990; Blichert-Toft et al., 1999; Montel et al., 2000; Pearson and Nowell, 2004; Garrido et al., 2011; Azdimousa et al., 2013; Mazzoli et al., 2013; Gueydan et al., 2019; Rossetti et al., 2010, 2020). Several studies have suggested an important role played by hyper-extension to exhume these mantle rocks up to intermediate depth before a subsequent emplacement in the upper crust (Kornprobst and Vielzeuf, 1984; Argles et al., 1999; Platt et al., 2003b; Précigout et al., 2013; Johanesen et al., 2014; van Hinsbergen et al., 2014; Johanesen and Platt, 2015; Frasca et al., 2017; Gueydan et al., 2019), but there is no consensus on the timing of this extensional episode. Proposed ages range from the early Permian (Rossetti et al., 2020; Acosta-Vigil et al., 2014) to the Jurassic (Michard et al., 1991; Sanchez-Rodriguez et al., 1996), the Late Oligocene or Early Miocene (Précigout et al., 2013; Frasca et al., 2017; Gueydan et al., 2019). Recent models also propose a Mesozoic hyperextension and mantle exhumation within the segmented rift system between Iberia and Africa (Fernàndez et al., 2019; Pedrera et al., 2020). The main reason for this lack of consensus is the clustering of most radiometric ages at ca. $20 \mathrm{Ma}$ in the whole Alpujárride/Sebtides realm mentioned above. This question is the major obstacle in the search of an evolution model of the entire orogen.

From this brief review of the geodynamic context of the Betic Cordillera three main questions arise: (i) Which is the timing of the HP-LT event (i.e. the age of the subduction zone metamorphism) in the Alpujárride-Sebtide and NevadoFilábride metamorphic complexes, hence the ages of the subduction episodes affecting the Alboran domain? (ii) Which is the significance of the observed clustering of radiometric ages around $20 \mathrm{Ma}$ despite a range of different methods with different closure temperatures? and (iii) What is the age and which are the mechanisms of emplacement of the subcontinental peridotite massifs of both the Rif and the Betics? We now summarize the geological context of the Alpujárride and Nevado-Filábride metamorphic complexes of the Betic Cordillera in more detail.

\section{Geological context of the Alboran Domain}

\subsection{Large-scale structure, the main complexes and contacts}

The Alboran Domain (Andrieux et al., 1971; Balanyá and García-Dueñas, 1987; Platt et al., 2013; Casciello et al., 2015) is traditionally divided in three major metamorphic complexes (Torres-Roldán, 1979). These are from top to bottom the Malaguide, the Alpujárride and the Nevado-Filábride Complexes in the Betics (Blumenthal, 1927; Torres-Roldán, 1979) (Figs. 2 and 4). While lateral equivalents of the Malaguide and Alpujárride Complexes can be found in the Rif, there respectively named Ghomarides and Sebtides (Kornprobst and Durand-Delga, 1985; Chalouan and Michard, 1990;
Chalouan et al., 2001, 2008), the Nevado-Filábride Complex is found only in the Betics. It is exposed below the Mecina and Filabres shear zones, a set of major detachments separating the Alpujárride at the hangingwall from the Nevado-Filábride at the footwall, in the core of the Sierra Nevada-Sierra de los Filabres and Sierra Alhamilla MCCs (Jabaloy et al., 1993; Martínez-Martínez et al., 2002; Augier et al., 2005a, 2005b; Agard et al., 2011) (Figs. 2 and 4). The contact between the Malaguide and the Alpujárride complexes corresponds to the MAC (Malaguide Alpujárride Contact) detachment (Lonergan and Platt, 1995; Vissers et al., 1995).

The metamorphic complexes making up the Alboran Domain were defined earlier based on the recognition of stacked units with the repetition of a simple sequence made of a Paleozoic basement and a Triassic cover essentially made of micaschists and marbles (Torres-Roldán, 1979). Each of these complexes has recorded its own metamorphic evolution. The Malaguide Complex does not show a significant Alpine metamorphic imprint while the Alpujárride and the NevadoFilábride complexes record a multi-stage Alpine metamorphism and deformation (see a synthesis in Gómez-Pugnaire et al., 2019). The observed maximum-temperature gradient in the Malaguide Complex is however interpreted as a progressive resetting of old radiometric ages during the Alpine episode showing some Alpine thermal record in this complex too (Negro et al., 2006).

The Alpujárride/Sebtides complex is further divided into several units with contrasted metamorphic evolutions (GarcíaDueñas and Navarro-Vila, 1976; Goffé et al., 1989; Azañón et al., 1992, 1994; Sanz de Galdeano and Andreo, 1995; Balanyá et al., 1997; Azañón and Goffé, 1997; Michard et al., 2006) (Figs. 4-7). Most of these units also show a common stratigraphic succession of the Permian-Triassic cover deposited on top of the Paleozoic basement, but the metamorphic grade can be very different from one place to another (Michard et al., 1997, 2006). Several recent publications have emphasized the possibility that a significant part of the high-temperature metamorphism found in the Paleozoic basement is of Paleozoic age and not Alpine as classically proposed (Montel et al., 2000; Rossetti et al., 2010, 2020; Sánchez-Navas et al., 2017; Gómez-Pugnaire et al., 2019). For instance, a recent detailed approach of the hightemperature metamorphism in the Torrox gneiss suggests that the high-temperature event is Late Paleozoic in age and not Alpine (Fig. 8) (Sánchez-Navas et al., 2017), a conclusion also reached for the entire Alpujárride Complex by GómezPugnaire et al. (2019). This possibility has been also proposed for the deepest granulitic units of the Alpujárride/Sebtides, forming the envelope of the Ronda peridotites. For this reason, in the following we present a re-appraisal of the metamorphic signature of the Alpujárride complex focusing mainly on the post-Permian metasedimentary cover in order to avoid confusion with the possible occurrence of Paleozoic assemblages in the basement units (see also Azañón and Goffé, 1997; Gómez-Pugnaire et al., 2019).

One then observes a wide range of $P-T$ conditions. Slightly metamorphosed units are found in Sierra de Lujar or Sierra de Gador. Very low-temperature HP-LT metamorphism is observed in the Sierra Alhamilla with the preservation of saliotite (Goffé et al., 1989). Similar HP-LT conditions are found in Salobreña Unit near Trevenque on the western flank 
of the Sierra Nevada with preserved parageneses with aragonite and Fe-Mg-carpholite. On the opposite, hightemperature and low-pressure (HT-LP) conditions are recorded in the marbles and gneiss of the Western Alpujárride in the Jubrique and Blanca units (Azañón and Goffé, 1997). A striking contrast is thus seen between the very cold HP-LT parageneses of the Sierra Alhamilla or parts of the Salobreña Unit that contain aragonite and Fe-Mg carpholite (Azañón and Goffé, 1997) and the higher-temperature Ojén eclogite-facies rocks in the Western Alpujárride (Tubía and Gil Ibarguchi, 1991).

Both the Alpujárride basement and the Triassic metasediments above share a common gently dipping foliation and HTLP metamorphic facies with the massive crystallization of post-tectonic andalusite and/or sillimanite even where the Triassic metasediments show H $P$-L $T$ parageneses (Simancas and Campos, 1993; Rossetti et al., 2005; Sánchez-Navas et al., 2017; Williams and Platt, 2018; Gómez-Pugnaire et al., 2019), thus implying a significant condensation of metamorphic isograds. This observation was interpreted as reflecting an episode of strong attenuation by extension after the first nappe stacking (Azañón et al., 1997; Azañón and Goffé, 1997; Azañón and Crespo-Blanc, 2000). Such condensed isograds are observed over the entire Alpujárride complex from Sierra de la Contraviesa in the center, all the way to the Jubrique Unit resting on top of the Ronda peridotite in the west (Crespo-Blanc et al., 1994; Crespo-Blanc, 1995; Lonergan and Platt, 1995; Balanyá et al., 1997; Negro et al., 2006; Platt et al., 2013; Williams and Platt, 2018). The situation of the basement units in the Western Alpujárride is in fact more complex as they either rest on top of the peridotite (Jubrique Unit) or below (e.g. Blanca or Guadaiza units) (Fig. 2).

Several episodes of deformation were recognized in the Alpujárride complex. The first episode (D1) is associated with the HP-LT parageneses and the second one (D2) with the contraction of isograds described above and thus interpreted as extensional (Martinez-Martinez and Azañón, 1997; Azañón and Crespo-Blanc, 2000; Rossetti et al., 2005; Williams and Platt, 2018). A third episode (D3) was compressional, reworking the extended stack and shortening it again, refolding the earlier D2 extensional detachments and producing a postHP-LT metamorphic nappe stacking (called D3 nappe stack in this paper; see Azañón and Crespo-Blanc, 2000). The main observed direction of stretching is N-S or NE-SW and the main sense of shear during D2 is top-to-the north (Crespo-Blanc et al., 1994; Azañón and Crespo-Blanc, 2000; Jolivet et al., 2003, 2008; Rossetti et al., 2005; Williams and Platt, 2018).

$P$-T-time paths recorded by the different tectonic units of the Alpujárride-Sebtide Complex are shown in Figure 5. The significance of $P-T$ paths can in general be discussed, whether they represent the actual $P-T$ evolution of the tectonic unit where the samples come from or are flawed by a certain amount of disequilibrium. We consider that, even when a rock has not been totally equilibrated, e.g. totally recrystallized with a paragenesis in full equilibrium with the new $P-T$ conditions along a given $P-T$ path, local equilibria observed in the thin sections represent steps along the $P-T$ path, especially when water-rich minerals are abundant, which is the case of most rocks in the Alpujárride-Sebtide and Nevado-Filábride complexes. This is one way of reconstructing $P-T$ paths and the reader is referred to detailed studies of this question
(Vidal and Parra, 2000; Parra et al., 2002; Trotet et al., 2006; Yamato et al., 2007; Laurent et al., 2018).

We first describe the shape of $P-T$ paths and leave the timing for a later discussion. Figure 5A shows the shape of $P-T$ paths in the Permo-Triassic metasediments for most units, except for the Filali Unit (Sebtides), the Ojén eclogites and the basement drilled during ODP Leg 161. Apart from the latter, most $P-T$ paths show a peak of pressure aligned on a single $\mathrm{H} P$ LT gradient of about $10^{\circ} / \mathrm{km}$ followed by an isothermal decompression path, before reaching a warmer gradient of about $60 \% \mathrm{~km}$. The Escalate and Sierra Alhamilla units show exceptionally cold decompression paths attested by the preservation of aragonite or saliotite. These last two $P-T$ paths and the alignment of pressure-peaks on an H $P$-LT gradient sign a subduction gradient and the isothermal retrograde paths are indicative of a fast exhumation. The internal organization of the Alpujárride Complex has been strongly reworked by the late compressional stage (D3) as shown by the position of the lower-pressure Lujar-Gador unit as the structurally deepest unit in the Alpujárride complex (Fig. 6A), implying that the different nappes have been superposed by thrusting after the peak of metamorphism and part of the exhumation took place (Azañón et al., 1994; Azañón and Goffé, 1997; Azañón and Crespo-Blanc, 2000). Figure $5 \mathrm{~B}$ shows the $P-T$ paths of the Ronda and Beni Bousera peridotites as well as those of associated high-temperature crustal units. The same isothermal decompression is observed for the HT-crustal units except for the very high temperature reached by the dynamothermal aureole of the Ronda peridotite.

The Nevado-Filábride Complex is also divided in several large-scale units (Figs. 2 and 4). From top to base, one finds the Bédar-Macael Unit, Calar Alto Unit and Ragua Unit (García-Dueñas et al., 1988, 1992; Jabaloy et al., 1993; Martínez-Martínez et al., 1997; López Sánchez-Vizcaíno et al., 2001; Augier et al., 2005a, 2005b). The two lower units are essentially made of dark metasediments including metapelites, metaquartzites and minor marbles, while the Bédar-Macael unit shows in addition thick marbles, lateVariscan orthogneiss, metabasites and ultramafic rocks interpreted as meta-ophiolites (Puga et al., 1999). The metamorphic grade has long been considered the highest in the Bédar-Macael Unit with eclogite-facies metabasites and metapelites (Augier et al., 2005a, 2005b; Platt et al., 2006 and references therein), but the recent study of Santamaria-Lopez et al. (2019) reveals almost similar peak-conditions in all three units (Fig. 9). The Calar Alto and Ragua units however show mostly upper greenschist-facies parageneses and a clear retrograde evolution toward the lower greenschist-facies when approaching the Filabres Shear Zone, but detailed study of the pelitic parageneses shows that it also experienced earlier eclogite-facies conditions. The main deformation observed in these three units is the second-stage foliation folded in the domes of the Sierra Nevada, Sierra de los Filabres and Sierra Alhamilla and the stretching lineation trends E-W in average (Platt and Vissers, 1989; García-Dueñas et al., 1992; Martínez-Martínez et al., 2002; Jabaloy et al., 1993; Augier et al., 2005a). Post-8 Ma compression further contributed to the domal shape of the Nevado-Filábride Complex as well as other domes in the Alpujárride Complex such as the Sierra de Gador (Weijermars et al., 1985; Sanz de Galdeano and Vera, 1992; Janowski et al., 2017). Detailed maps show a divergence 

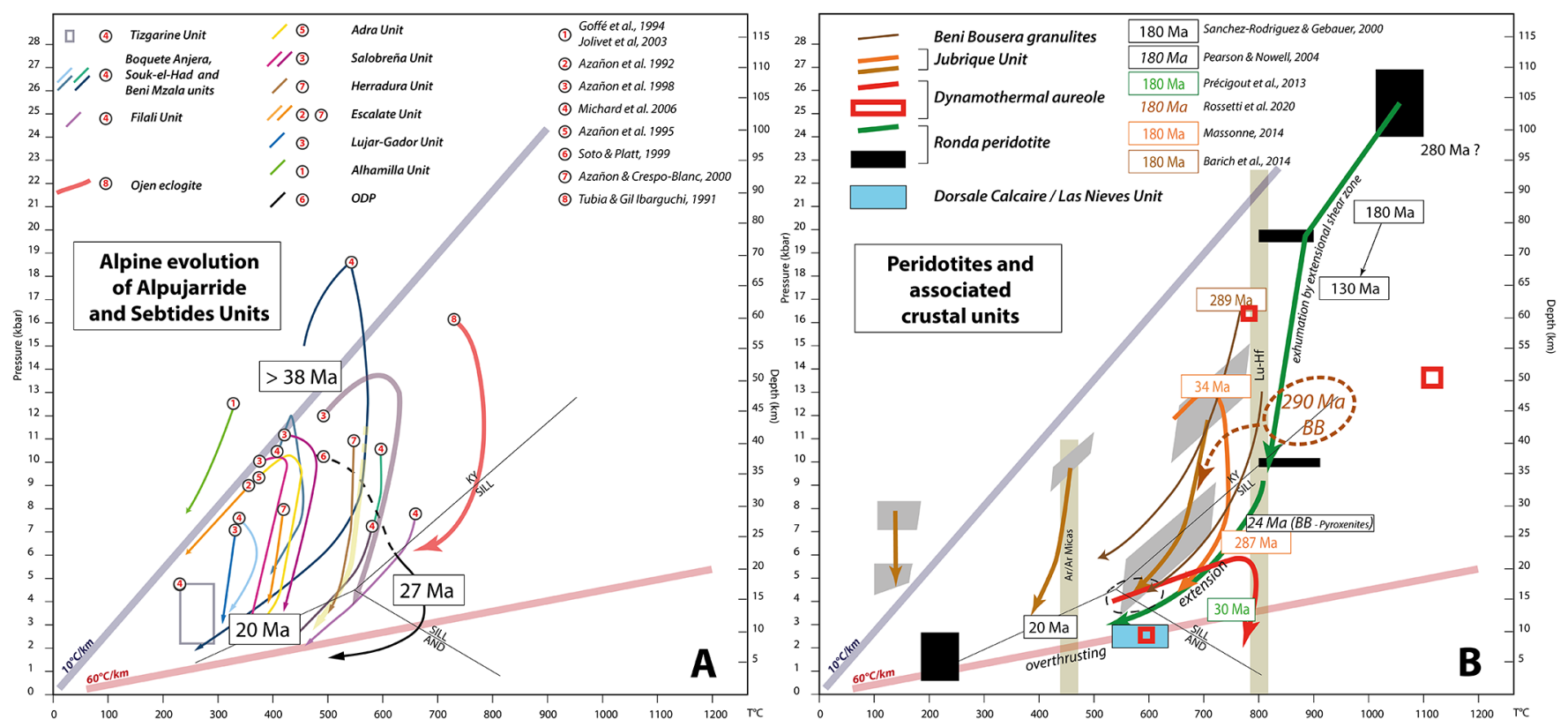

Fig. 5. P-T-time evolution of the Alpujárride complex. A: $P$-T paths of the different units of the Alpujárride complex (Tubía and Gil Ibarguchi, 1991; Azañón et al., 1992, 1998; Goffé et al., 1994; Balanyá et al., 1997; Soto and Platt, 1999; Azañón and Crespo-Blanc, 2000; Booth-Rea et al., 2005; Chalouan et al., 2008; Massonne, 2014) and some age constraints after Platt and Whitehouse (1999) and Bessière (2019). B: P-Ttime constraints from the Ronda and Beni Bousera peridotites and neighboring high-temperature crustal units (Sánchez-Rodríguez and Gebauer, 2000; Pearson and Nowell, 2004; Précigout et al., 2013; Acosta-Vigil et al., 2014; Barich et al., 2014; Massonne, 2014; Barich, 2016; Rossetti et al., 2020).

of the lineation trend on either sides of the domes, NW-SE trending on the northern side and NE-SW trending on the southern side associated with overall top-to-the west sense of shear and strong localization of deformation toward the Filabres Shear Zone (Augier et al., 2005a, 2005b; Agard et al., 2011). $P$ - T paths show essentially an isothermal decompression during exhumation (Puga et al., 2000; Augier et al., 2005a; Platt et al., 2006; Santamaria-Lopez et al., 2019). The two main domes are flanked by Miocene extensional basins where evidence of syntectonic sedimentation are commonly observed (Augier et al., 2005a, 2005b, 2013; Meijninger and Vissers, 2006). The Huercal-Overa Basin was deposited until the Tortonian above a detachment connected to the Filabres Shear Zone. The direction of extension shows a strong rotation from the deepest parts of the domes (E-W) up to the synsedimentary normal faults controlling the basins (almost N-S) (Augier et al., 2005a, 2013).

The post HP-LT metamorphic D3 nappe stack of the Internal Zones was thus reworked by two stages of extension and several low-angle extensional detachments (GarcíaDueñas et al., 1992; Crespo-Blanc et al., 1994; Crespo-Blanc, 1995; Balanyá et al., 1997; Martínez-Martínez et al., 2002) (Figs. 2 and 4). The MAC and the Mecina-Filabres detachment concentrated most of the deformation, but several smallerscale detachments have been described within the Alpujárride Complex (Crespo-Blanc et al., 1994; Crespo-Blanc, 1995). The present-day superimposition of units with different maximum pressure shows the position of the main extensional structures that have accommodated the largest part of crustal thinning (Figs. 2, 4, 6 and 7). The MAC has the low-pressure Malaguide Complex in its hanging-wall and the HP-LT
Alpujárride complex in the footwall, with a large pressure gap showing the amount of extension (Lonergan and Platt, 1995). The Mecina and the Filabres shear zones carry the Alpujárride Complex in their hanging-wall and the eclogite-facies BédarMacael unit in their footwall, showing again a gap of pressure with higher pressure downward (Jabaloy et al., 1993; Martinez-Martinez and Azañón, 2002; Martínez-Martínez et al., 2002). Although the peak conditions in the three main Nevado-Filábride units are similar according to the recent study of Santamaria-Lopez et al. (2019) the basal contact of the Bédar-Macael unit brings marbles, metabasites and ultramafic rocks of oceanic origin (Puga et al., 1995, 2017) on top of continental material and was thus a thrust in the first place, before the extensional reactivation (García-Dueñas et al., 1988, 1992; Jabaloy et al., 1993).

\subsection{Neogene basins and tectonic evolution}

Neogene basins were deposited on top of the Alboran Domain from the early Miocene onward (Bourgois et al., 1972; Feinberg et al., 1990; Crespo-Blanc et al., 1994; Comas et al., 1999; Montenat and Ott d'Estevou, 1999; Serrano et al., 2006; Iribarren et al., 2009; Do Couto et al., 2016) (Fig. 2). Several infill stages can be recognized in the interactions between regional tectonic deformation and basin formation (Briend et al., 1990; Montenat and Ott d'Estevou, 1990, 1999; Martínez-Martínez et al., 2004; Serrano et al., 2006; Clauzon et al., 2015; Do Couto et al., 2015, 2016). Brittle low-angle normal faults formed in two main stages, before and after the late Langhian (Crespo-Blanc et al., 1994). The first set is 

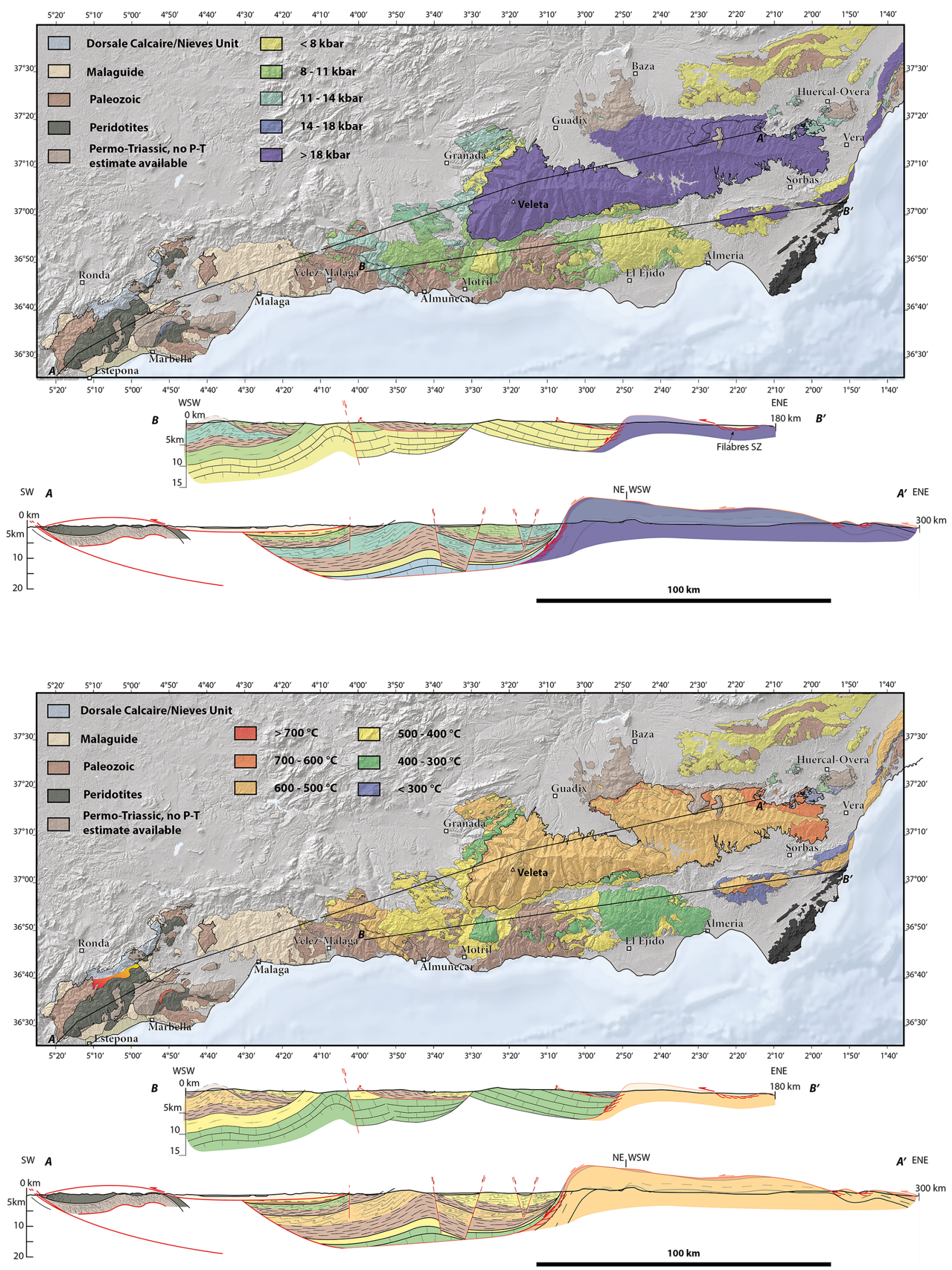

Fig. 6. Maps and cross-sections (see Fig. 4) of the Internal Zones of the Betics showing the peak pressure (upper) and temperature (lower) conditions in the different units. No P-T constraints are available in the weakly or non-metamorphosed External Zones. 

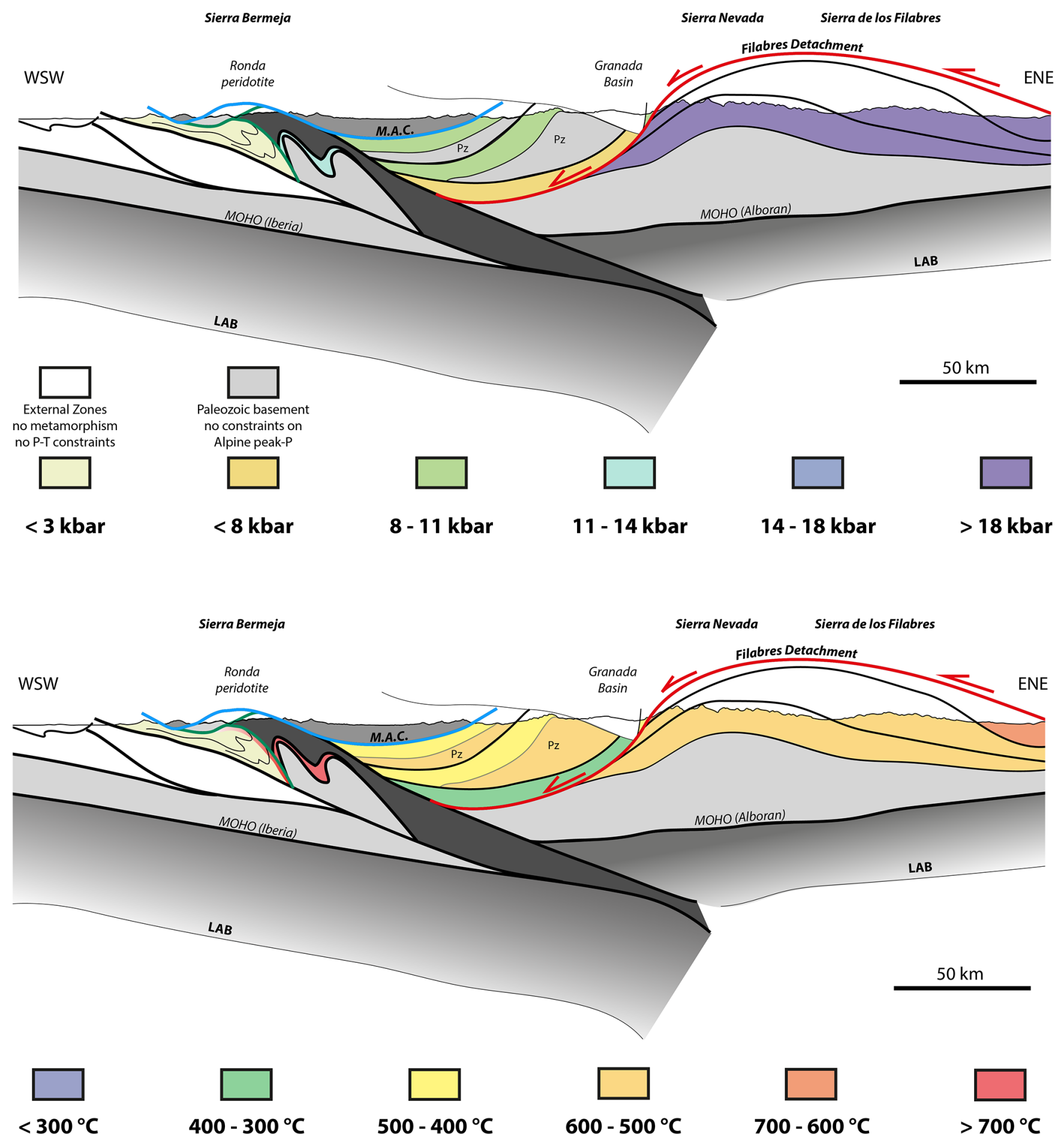

Fig. 7. E-W cross-sections (see Fig. 2) of the Internal Zones of the Betic at lithospheric scale showing the peak pressure (upper) and temperature (lower) conditions in the different units.

mainly coeval with the exhumation of the Alpujárride Complex and the top-to-the north kinematics, while the second set is associated with the exhumation of the NevadoFilábride Complex. The direction of brittle extension during the second episode is variable from one place to the other and seems strongly controlled by the formation and amplification of extensional domes (Martínez-Martínez et al., 2004; Augier et al., 2005a, 2013). During this period, maximum thinning is recorded in the now-offshore domain (Comas et al., 1992, 1999; Do Couto et al., 2016). Deep sea drilling has recovered high-temperature metamorphic rocks attributed to the Alpujárride Complex in the Alboran Basin and the peak of temperature was dated around $27 \mathrm{Ma}$ (Comas et al., 1999; Soto and Platt, 1999). The basement of the Alboran Sea is likely 


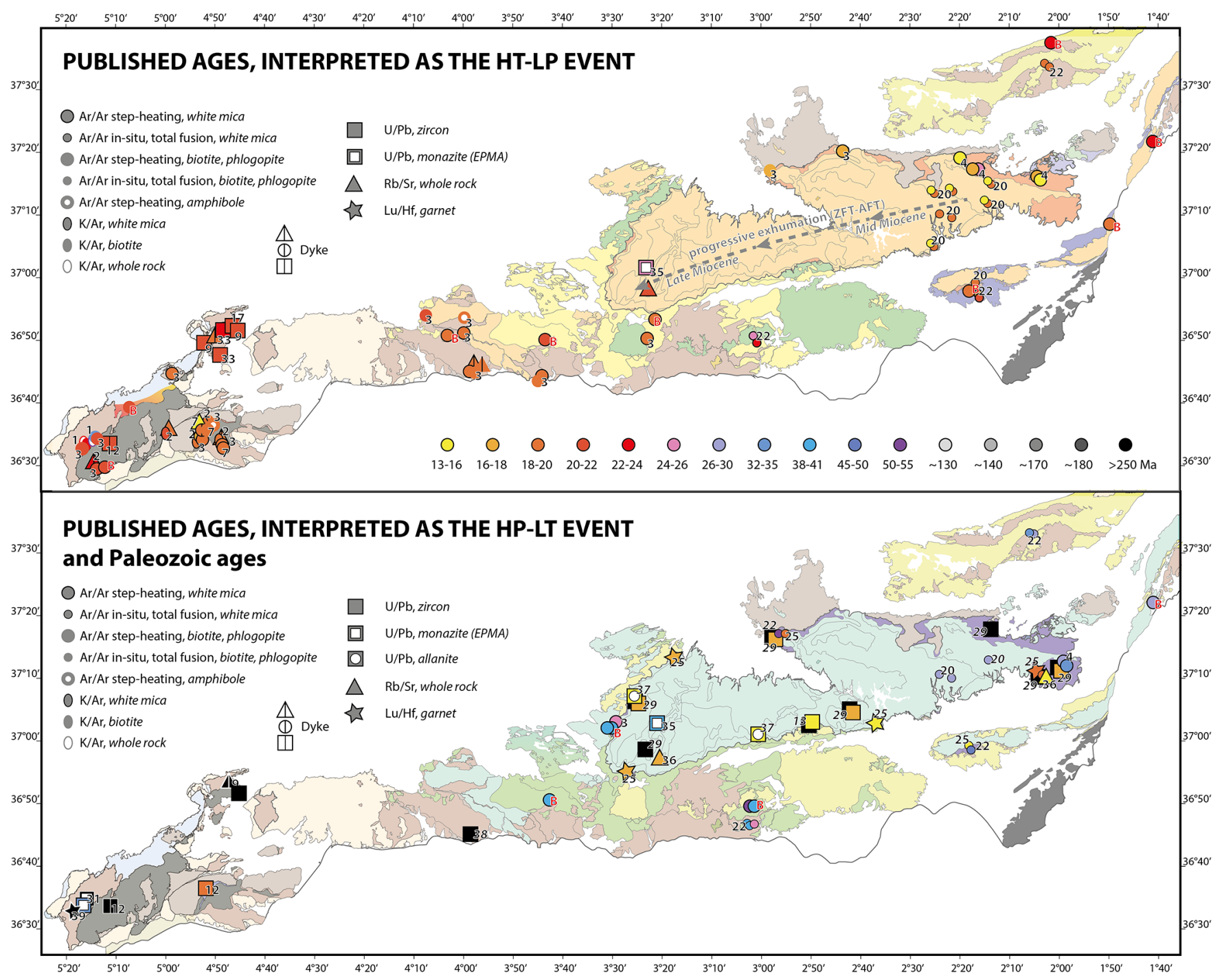

Fig. 8. Maps compiling the available radiometric ages in the Alpujárride and Nevado-Filábride complexes. See figure 3 for references. Samples marked B refer to those dated by Bessière (2019).

mostly made of rocks belonging to the Alpujárride-Sebtide Complex and partly to the Malaguide-Ghomaride Complex (Soto and Platt, 1999; Sánchez-Gómez et al., 1999; Olivier and Paquette, 2018).

The thick sedimentary sequence of the West Alboran basin (WAB, up to $9 \mathrm{~km}$ thick) was mainly deposited from the Burdigalian or even the Aquitanian to the Late Tortonian (Bourgois et al., 1992; Comas et al., 1992, 1996, 1999, Chalouan et al., 1997; Soto and Platt, 1999; Sautkin et al., 2003; Do Couto et al., 2016; de la Peña et al., 2020). The detachments described on land probably extended offshore during the Burdigalian and controlled the first deposits in the WAB (García-Dueñas et al., 1992; Comas et al., 1992, 1999; Do Couto et al., 2016). Later sedimentation led to the accumulation of a very thick sequence without any significant migration of the depocenter as shown by the analysis of the successive sedimentary sequences on seismic profiles (Do Couto et al., 2016). The WAB was formed as a sag basin transported westward above the retreating slab (Do Couto et al., 2016). During the same period, flysch-type deposits filled the migrating trench/foreland basin (Daudet et al., 2020).

A major tectonic/geodynamic change then occurred at about $8 \mathrm{Ma}$ ago, when the present-day compressional regime started. The Miocene basins were subjected to tectonic inversion and the metamorphic domes amplified, now forming the highest reliefs of the Betic Cordillera (Weijermars et al., 1985; Vissers et al., 1995; Augier et al., 2013). The previously formed basins were then folded and cut by large-scale transcurrent faults that cross the entire Alboran Sea and reverse faults (de Larouzière et al., 1988; Booth-Rea et al., 2004; Martínez-García et al., 2013, 2017; Do Couto et al., 2014; Estrada et al., 2017; Janowski et al., 2017; d'Acremont et al., 2020; Lafosse et al., 2020). This compressional regime combined with the eustatic fluctuations are responsible for the closure of the narrow corridor between the Atlantic Ocean and the Mediterranean Sea, triggering the Messinian salinity crisis (Cita, 1973; Hsü et al., 1973, 1978; Gautier et al., 1994; Clauzon 

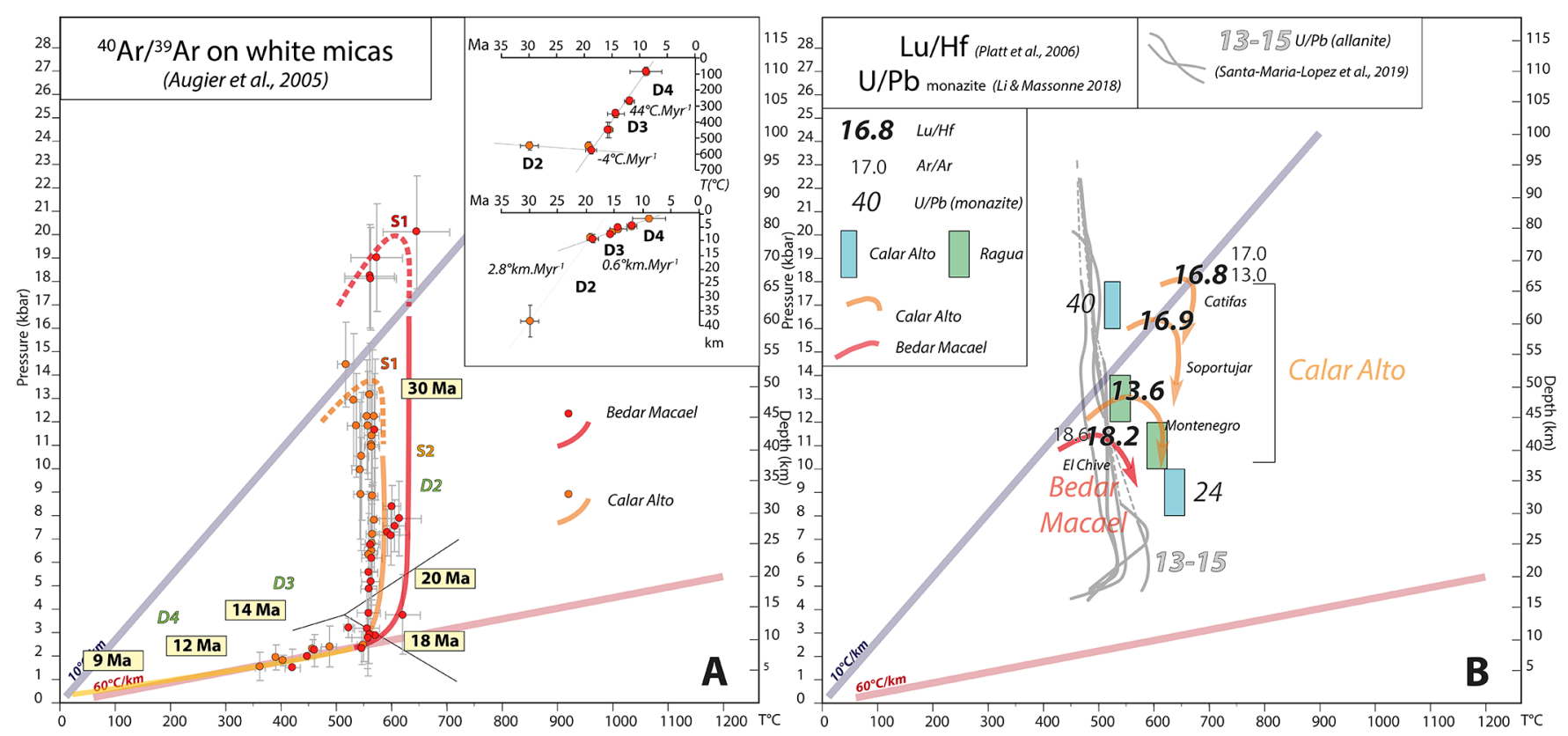

Fig. 9. $P$-T-time constraints for the Nevado-Filábride complex. A: $P$-T-time evolution after Augier et al. (2005b). The inset shows the temperature-time $(T-\mathrm{t})$ and depth-time (Z-t) evolutions. Despite a probable slightly higher maximum temperature in the Bédar-Macael unit than in Calar Alto, available ages and error bars on the P-T estimates do not allow showing separate $T$ - $t$ and Z-t paths. B: other available data from Platt et al. (2006), Li and Massonne (2018) and Santamaria-Lopez et al. (2019).

et al., 1996; Krijgsman et al., 1999; Garcia-Castellanos and Villaseñor, 2011).

In the following, we introduce the major questions addressed in this paper, namely (i) the significance of the observed clustering of radiometric ages around $20 \mathrm{Ma}$, (ii) a discussion of the debated age of the HP-LT event in the Alpujárride and Nevado-Filábride Complexes and (iii) the emplacement mechanism of the Ronda peridotite body.

\subsection{Geochronological constraints and the $20 \mathrm{Ma}$ event}

As shown on Figures 3,8 and 10, numerous radiochronological data over the whole Internal Zones of the Betics and the Rif, especially in the Alpujárride/Sebtides Complexe show a strong clustering of ages between 24 and 18 Ma with different methods in the two regions, from $\mathrm{U} / \mathrm{Pb}$ on zircon to ${ }^{40} \mathrm{Ar} /{ }^{39} \mathrm{Ar}$ on micas (see figure caption for references, see also Gómez-Pugnaire et al. (2019) for a compilation). These ages were acquired on metamorphic rocks of both complexes in the whole Internal Zones, from the migmatite leucosomes or granitic dykes intruding the peridotites in the west, to the lower-grade Alpujárride micaschists in the centre and east. This compilation gathers all sorts of available data, acquired with a large variety of methods since 1975. All references are given in the caption of Figure 3. Dating methods are the following: $\mathrm{U} / \mathrm{Pb}$ on zircon, monazite and allanite, $\mathrm{Lu} / \mathrm{Hf}$ on garnet, $\mathrm{Sm} / \mathrm{Nd}$ on clinopyroxene, $\mathrm{K} / \mathrm{Ar}$ on plagioclase and biotite, ${ }^{40} \mathrm{Ar} /{ }^{39} \mathrm{Ar}$ on biotite, phlogopite, white-micas and amphibole, whole rock $\mathrm{Rb} / \mathrm{Sr}$ isochrons, zircon and apatite fission-tracks. These data, acquired with different methods applied to different minerals, are often interpreted solely based upon the closure-temperature concept but other parameters such as fluid-rock interactions or strain intensity may imply more complex interpretations (e.g. Rossetti et al., 2010; Sánchez-Navas et al., 2014; Beaudoin et al., 2020), which we discuss here.

The variety of the adopted geochronological methods include high-temperature systems like $\mathrm{U} / \mathrm{Pb}$ on zircons, intermediate-temperature systems like ${ }^{40} \mathrm{Ar} /{ }^{39} \mathrm{Ar}$ on white micas and also low-temperature thermochronology like fission tracks on apatite, which allows exploring the whole $P$ - $T$ space. Figures 8 and 10 show the distribution on results in the Betics and the Rif; most ages appear even more clustered around 18$22 \mathrm{Ma}$. The fact that all methods yield very similar ages pleads in favor of an extremely short event at the turn of the Oligocene and Miocene, encompassing exhumation from mantle depth of the Ronda peridotite and its emplacement within the upper crust, associated with fast cooling, or a short thermal event (Platt and Whitehouse, 1999; Rossetti et al., 2010; Platt et al., 2013; Précigout et al., 2013). The exact significance of this event is however not clear, whether it corresponds to a short tectonic event associated with a thermal peak or a fast cooling event (Platt et al., 1998, Soto and Platt, 1999). The NevadoFilábride Complex has also recorded ages at this same period but it also shows younger ages, until the Middle Miocene (López Sánchez-Vizcaíno et al., 2001; Platt et al., 2006), and fission-track data show a progressive exhumation below the extensional Filabres Shear zone lasting until the late Miocene (Johnson et al., 1997). The exhumation of the Alboran Domain thus proceeded sequentially, starting with the AlpujárrideSebtide Complex and continuing with the Nevado-Filábride Complex. The observation that early Miocene sediments were deposited on exhumed Alpujárride units, including the mantle 
peridotite (Bourgois et al., 1972; Serrano et al., 2006), questions the significance of this clustering of ages within such a short period that is almost coeval with the deposition of the first unconformable sediments.

\subsection{Age of the HP event metamorphism in both complexes}

Figures 3 and 8 show a compilation of ages attributed by the authors to the peak of pressure with the addition of older (Paleozoic) ages retrieved from zircons (see figure caption for references). Most such ages have been acquired in the central and eastern Betics, both in the Nevado-Filábride and Alpujárride Complexes with different methods, mainly $\mathrm{U} / \mathrm{Pb}$ on zircon or monazite and ${ }^{40} \mathrm{Ar} /{ }^{39} \mathrm{Ar}$ on white micas. Two agegroups can be identified on this compilation, Eocene ages and Miocene ages. Eocene ages are found in the micaschists of the central and eastern Alpujárride Complex $\left({ }^{40} \mathrm{Ar} /{ }^{39} \mathrm{Ar}\right.$ on white micas) and locally in the Nevado-Filábride Complex $\left({ }^{40} \mathrm{Ar} /{ }^{39} \mathrm{Ar}\right.$ on white micas and $\mathrm{U} / \mathrm{Pb}$ on monazite), when Oligocene and Miocene ages are more regionally distributed. An Eocene age is also found in the Jubrique unit $(\mathrm{U} / \mathrm{Pb}$ on monazite) in the western part of the Alpujárride Complex. In the Rif, the available geochronological data only provide a minimum age of 28-29 Ma for the HP-LT event in the Sebtides, except K-Ar ages on amphibole and white mica in the Beni Mzala window (Michard et al., 2006; Homonnay et al., 2018) (Fig. 10).

Miocene ages are found in the Nevado-Filábride Complex, in the Bédar-Macael and Calar-Alto Units, leading some authors to conclude that the Nevado-Filábride Complex had not been subducted before the Early Miocene (López SánchezVizcaíno et al., 2001; Platt et al., 2006). Note that this timing for subduction of the Nevado-Filábride Complex overlaps with the Early Miocene event in the Alpujárride Complex. The age of the HP-LT event is in fact debated (Fig. 9). Augier et al. (2005a) based on a detailed study of the $P$-T-time evolution of syn-kinematic white-micas in the Bédar-Macael and Calar Alto units show a regular evolution of ages along the retrograde P-T paths, from more than $30 \mathrm{Ma}$ for the highest pressure conditions to about $14 \mathrm{Ma}$ for the last record at the brittle-ductile transition, consistent with LT thermochronology. In this case, the evolution of ages is correlated with the chemical composition and thus the $P-T$ conditions of phengite growth and with progressive deformation. Insets in Figure 9 show this evolution also on $P$-time and $T$-time diagrams. Correlation of these $P$-T-time paths with deformation for the Calar Alto and Bédar-Macael units show that the pressure decrease is associated with a succession of deformation stages and progressive strain localization along the Filabres Shear Zone with a top-to-the west sense of shear.

This timing seems in a first approach incompatible with the middle Miocene ages obtained by López Sánchez-Vizcaíno et al. (2001) through U/Pb SHRIMP dating on zircon from the Cerro de Almirez ultramafic Complex, which are interpreted as testifying for the peak of pressure. Using a different approach, Platt et al. (2006) dated garnets from eclogite-facies rocks from the Calar Alto and Bédar-Macael units with the Lu/Hf method. The four samples they dated have recorded HP-LT conditions and they all return young ages between 13 and
$17 \mathrm{Ma}$. Some ${ }^{40} \mathrm{Ar} /{ }^{39} \mathrm{Ar}$ laser probe ages on white micas yield very similar ages, which is taken as an indication of fast exhumation. The peak of pressure is thus considered to be of Miocene age by Platt et al. (2006) (Fig. 5). It should be noted here that the $P-T$ estimates of the peak of metamorphism associated with these young ages in Platt et al. (2006) are not fully compatible with those obtained by Augier et al. (2005a). The peak conditions in Bédar-Macael unit are found lower than in Calar Alto Unit at variance with the recent study of Santamaria-Lopez et al. (2019). Kirchner et al. (2016) dated eclogites and micaschists in the Nevado-Filábride Complex with $\mathrm{Rb} / \mathrm{Sr}$ isochrons and obtained ages between 20 and $13 \mathrm{Ma}$, which they relate to the $\mathrm{H} P$ stage. Like Platt et al. (2006) and Behr and Platt (2012), Kirchner et al. (2016) question the significance of the ${ }^{40} \mathrm{Ar} /{ }^{39} \mathrm{Ar}$ ages obtained by Augier et al. (2005a) that would be stained with excess argon because they contradict the Lu/Hf ages, neglecting the good correlation between (i) $P-T$ evolution, (ii) the succession of deformations and (iii) ages shown in Augier et al. (2005a). While this study focused on Triassic protoliths, Behr and Platt (2012) performed their analysis on Paleozoic rocks that may explain "old", meaningless ages that simple reflect Ar inheritance rather than genuine excess Ar. More recently, Li and Massonne (2018) provided microprobe U-Th- $\mathrm{Pb}$ dating results from monazite grains from the Calar Alto and Ragua Units. These authors find two groups of ages, one $\mathrm{H} P$ group centered on $40 \mathrm{Ma}$ and one LP group centered on $\sim 24 \mathrm{Ma}$. They interpret these two groups as two successive $P-T$ loops, a situation that is not suggested by the continuous decrease of pressure recorded by the chemistry of white micas in Augier et al. (2005a) or the $P-T$ estimates obtained in several other studies (GómezPugnaire and Fernandez-Soler, 1987; Puga et al., 1999, 2000; Platt et al., 2006).

The peak HP-LT conditions published by Augier et al. (2005a) and Li and Massonne (2018) were recently confirmed by Santamaria-Lopez et al. (2019) with the significant difference that all three units of the Nevado-Filábride Complex have recorded a similar peak of pressure at $\sim 20-22 \mathrm{kbar}$ and $500-550{ }^{\circ} \mathrm{C}$ and a second higher peak of temperature at lower pressure and higher temperature around 5-6 kbar and 500 $600{ }^{\circ} \mathrm{C}$. U/Pb dating on allanite constrains the $\mathrm{L} P-\mathrm{H} T$ stage at 13-15 Ma (Santamaria-Lopez et al., 2019).

The ${ }^{40} \mathrm{Ar} /{ }^{39} \mathrm{Ar}$ method on white micas and the U/Pb method on monazite thus both give Eocene ages ( $>30 \mathrm{Ma}$ and $40 \mathrm{Ma}$, respectively) for the peak of pressure in the NevadoFilábride Complex. The younger age group found with the $\mathrm{U} / \mathrm{Pb}$ method on monazite $(24 \mathrm{Ma})$ is older than the young ages (13-17 Ma) found with the Lu/Hf method. The discrepancy between results of the ${ }^{40} \mathrm{Ar} /{ }^{39} \mathrm{Ar}$ and $\mathrm{Lu} / \mathrm{Hf}$ method for dating the peak metamorphic conditions is not yet explained. Platt et al. (2006) and Kirchner et al. (2016) got rid of the ${ }^{40} \mathrm{Ar} /{ }^{39} \mathrm{Ar}$ data set by suggesting that the sample were characterized with excess argon without demonstration. The argon data set however has for it the progressive coeval evolution of deformation, chemistry and age and it is confirmed by the $\mathrm{U}-\mathrm{Pb}$ method on monazite. According to Scherer et al. (2000) the closure temperature of the $\mathrm{Lu} / \mathrm{Hf}$ method is strongly sensitive to the size of garnet grains, ranging from about $800^{\circ} \mathrm{C}$ for large ones $(4 \mathrm{~cm})$ to $540^{\circ} \mathrm{C}$ for small garnets $(0.24 \mathrm{~mm})$. In Platt et al. (2006), the dated garnets are relatively small $(\sim 1-2 \mathrm{~mm}$; see Platt et al., 2006, Supplementary Materials) and the closure 
temperature could be rather low, close to the peak temperature and to the temperature during isothermal exhumation and the ages could represent any part of the retrograde $P-T$ path. This is one possibility to reconcile the three data sets. As discussed in depth elsewhere (e.g. Beaudoin et al., 2020), the significance of ${ }^{40} \mathrm{Ar} /{ }^{39} \mathrm{Ar}$ white mica ages in the context of deformation involves both the concept of closure- $T$ (in the Dodsonian sense, Dodson, 1973) along with the concept of dynamic closure whereby thermally-induced Ar diffusion interacts with deformation-induced subdomains in the case of cold $P / T$ paths $<450-500{ }^{\circ} \mathrm{C}$, as recorded here. Ar retention/resetting can be dominated by recrystallization (over diffusion), locally producing an array of apparent ages at the scale of a single sample that do not conform with theoretical grain size trends in cooling ages but rather reflect the sequence of overprinting/ recrystallization steps recorded at the mineral scale. The final Ar record can be highly $P$-T-strain specific, explaining why markedly different ${ }^{40} \mathrm{Ar} /{ }^{39} \mathrm{Ar}$ patterns have been reported without necessarily requiring the effect of excess $\mathrm{Ar}$ incorporation.

\subsection{Age and mechanism of emplacement of the Ronda peridotite}

The Ronda peridotite is distributed in several sub-massifs, the largest of them in the Sierra Bermeja. The mantle rocks are systematically associated with lower crustal units where HTLP conditions in the field of anatexy are observed along the contact (Dürr, 1963; Loomis, 1975; Westerhof, 1977; Lundeen, 1978; Tubía and Cuevas, 1986; Tubía et al., 1997; Platt et al., 2003a, 2003b; Mazzoli et al., 2013; Acosta-Vigil et al., 2014; Barich et al., 2014; Barich, 2016). The Jubrique Unit is one of such units; it shows a strong downward gradient of maximum temperature from Permo-Triassic phyllites and sandstones at the top, to granulites and kinzigites at the bottom of the sequence (Loomis, 1972a, 1972b; Torres-Roldán, 1979; Balanyá et al., 1997; Negro et al., 2006) (Fig. 11). Metamorphic isograds are strongly condensed, showing a high thermal gradient and possible crustal thinning, possibly coeval with that observed in the Alpujárride and Sebtide units in general (Balanyá et al., 1997; Argles et al., 1999; Homonnay et al., 2018; El Bakili et al., 2020).

\subsubsection{Geometrical relations}

The Jubrique Unit is currently resting above the Ronda peridotite through a steep NW-dipping contact. Investigations along this contact have revealed the existence of a left-lateral, or top-to-the SW shear zone, the Bermeja-Jubrique Shear Zone (Balanyá et al., 1997), interpreted by most authors as an extensional shear zone (Précigout et al., 2013; Johanesen et al., 2014; Johanesen and Platt, 2015). The western contact of the peridotite extends towards the NE, changing its dip towards the SE. There, the peridotite and an underlying small slice of the Jubrique unit are placed on top of the Mesozoic sediments of the Nieves Unit (Dorsale Calcaire). Due to these geometrical relationships, these contacts (base of the Jubrique slice and base of the peridotites) were classically interpreted as thrusts (Mazzoli and Martin-Algarra, 2011; Mazzoli et al., 2013), connected with the thrust contact of the Jubrique Unit on top of the Nieves Unit. Ductile deformation and high-temperature metamorphism are both observed in a narrow zone $(\sim 2-3 \mathrm{~km}$ across strike) with a steep metamorphic gradient. This HT narrow zone has been interpreted as the result of the overthrusting of a hot slab of peridotite on top of the Nieves Unit sediments. Following the study of van der Wal and Vissers (1996), Mazzoli and Martin-Algarra (2011) and Mazzoli et al. (2013) propose a subduction channel model where the hot peridotite is exhumed by deep thrusts and the Nieves cover is deformed and metamorphosed underneath. The situation of the Blanca and Guadaiza units, belonging to the Alpujárride Complex, is classically interpreted in the same way. They are described as tectonic windows lying below the peridotite unit, showing a so-called dynamothermal aureole along the contact where partial melting is observed (Lundeen, 1978; Tubía and Cuevas, 1986; Esteban et al., 2008). Other basement units are instead without doubt lying on top of the peridotite near the contact with the Nieves Unit, similarly to Jubrique Unit. The Robledal klippe is one example (Bessière, 2019) and Sanz de Galdeano et al. (Sanz de Galdeano and Andreo, 1995; Sanz de Galdeano, 2017) propose a completely different geometry of the region with the basement units lying systematically on top of the peridotite (Fig. 11). The case of Guadaiza unit has been recently particularly discussed in these papers. Figure $11 \mathrm{C}$ shows an oblique view on this region where the 1:50.000 geological map of Marbella (Piles Mateo et al., 1973 ) is superimposed on top of the Google Earth relief image. Guadaiza Unit crops out in a depressed area and the first order geometry suggests that it underlies the topographically higher nearby Ronda peridotite (Lundeen, 1978; Tubía and Cuevas, 1986). Several points shown by the white arrows on Figure 11 however suggest that the situation is more complex and that the contact around Guadaiza unit has to be severely folded. The situation of this contact is thus not as simple as a slab of peridotite on top of crustal units and the proposition of Sanz de Galdeano et al. (Sanz de Galdeano and Andreo, 1995; Sanz de Galdeano, 2017) stating that the basement units are systematically resting above the peridotite should be further explored. At least, the position as a klippe of the Robledal gneiss makes no doubt on this image and it is thus in a position similar to Jubrique Unit, resting on top of the peridotite.

\subsubsection{P-T conditions}

$P-T$ conditions in and around the Ronda peridotite massif are shown on Figure 5B. The peridotite records a continuous evolution from mantle conditions to low-pressure and lowtemperature serpentinisation. The $P-T$ path shows a progressive exhumation of the peridotite from underneath the Jubrique crustal unit, or its equivalent in the Rif, and the Nieves unit Mesozoic sediments. The contact with the Nieves cover was reached at low pressure, no more than 3 kbar (Loomis, 1972a, 1972b; Tubía and Cuevas, 1986; Mazzoli and Martin-Algarra, 2011; Mazzoli et al., 2013). The dynamothermal aureole records variable evolutions such as a strong temperature increase toward the contact with the peridotite from about $500{ }^{\circ} \mathrm{C}$ to almost $800^{\circ} \mathrm{C}$ along the contact of Guadaiza unit (Esteban et al., 2008) or a temperature and pressure decrease from eclogite-facies conditions to HT-LP conditions near the Sierra Alpujata peridotite (Tubía et al., 1997). 
The peridotite massif shows a distribution of lithological facies that results from its exhumation and the progressive localization of deformation. Obata (1980) mapped their distribution within the massif. $P-T$ conditions estimated in the peridotite record its progressive exhumation from $\sim 24$ $27 \mathrm{kbar}$ and $1000-1100^{\circ} \mathrm{C}$ to $\sim 10 \mathrm{kbar}$ and $800-900^{\circ} \mathrm{C}$, and finally to low-temperature conditions (Obata, 1980; Garrido and Bodinier, 1999; Sánchez-Rodríguez and Gebauer, 2000; Garrido et al., 2011). The eastern part, far from the BermejaJubrique Shear Zone, is made of a plagioclase peridotite. It grades into a granular peridotite, then a spinel tectonite and finally garnet-spinel mylonite along the contact with Jubrique Unit (van der Wal and Vissers, 1996). Different interpretations of this distribution of facies have been published. Obata (1980), van der Wal and Bodinier (1996), Lenoir et al. (2001), Garrido et al. (2011) and Précigout et al. (2013) consider the granular peridotite as lithospheric mantle asthenospherized in a late stage. Johanesen and Platt $(2014,2015)$ instead describe the percolation of a melt in an earlier peridotite and a progressive deformation and formation of the western mylonite, an idea already suggested by Garrido and Bodinier (1999). The peridotite massif is also invaded by garnetpyroxenite layers, diversely deformed, witnessing early episodes of mantle melting during decompression (SánchezRodríguez and Gebauer, 2000; Garrido et al., 2011; Précigout et al., 2013).

\subsubsection{Ages}

The age of the HT-LP metamorphism and the age of exhumation are debated (Gómez-Pugnaire et al., 2019). One important constraint is the reworking of serpentinite and Alpujárride rocks at the base of the Viñuela formation of early Burdigalian age, thus about $20 \mathrm{Ma}$ (Bourgois et al., 1972; Serrano et al., 2006). Sánchez-Rodríguez and Gebauer (2000) provided zircon $\mathrm{U}-\mathrm{Pb}$ ages from the pyroxenite layers and obtained two groups of magmatic ages, one around $280 \mathrm{Ma}$ and one between 180 and 130 Ma. Rims of these zircons provide young ages around $20 \mathrm{Ma}$ which they interpret at witnessing peak-temperature conditions. The Mesozoic ages fit the rifting history of the Tethys Ocean with several events in the Permian and Triassic, in the Early Jurassic and others until the Early Cretaceous. Jurassic and early Cretaceous rifts are found all around the Iberian plate, from the nearby Gulf of Cádiz, the Rif, the Pyrenees, the Cantabrian basin, the Galicia margin, the Columbretes basin in the southern Valencia Trough and the Maestrat and Cameros basins in the Iberian Range (Boillot et al., 1988; Roca and Guimerà, 1992; Salas and Casas, 1993; Salas et al., 2001; Lagabrielle and Bodinier, 2008; Michard et al., 2014, 2020; Ramos et al., 2017; Etheve et al., 2018; Asti et al., 2019; Gimeno-Vives et al., 2019; Rat et al., 2019). Similarly, Permo-Carboniferous ages are retrieved from zircons in the anatectic granulites forming the envelope of the Beni Bousera peridotites, allowing Rossetti et al. (2020) to propose that the first exhumation of the Beni Bousera peridotite was coeval with late Variscan extension in the Permian and that the Early Miocene ages correspond to a late event, while the peridotite was already high in the crust. However, Pearson and Nowell (2004) dated pyroxenites in Beni Bousera massif with the $\mathrm{Lu} / \mathrm{Hf}$ method and suggested that the massif has cooled below $\sim 800^{\circ} \mathrm{C}$ some $24 \mathrm{Ma}$ ago.

\subsubsection{History of deformation in the peridotite}

Important constraints come from the relative timing of partial melting and the crystallization of garnets in the basal part of Jubrique Unit and in Ojén Nappe at the contact with the Sierra Alpujata peridotite massif. The observation of melt inclusions and nanogranites within garnets (Bartoli et al., 2013; Barich et al., 2014; Massonne, 2014) shows that garnets crystallized in the conditions of partial melting. Massonne (2014) considers this high-temperature event as the result of the progressive burial of the peridotite and neighboring crustal units during the Eocene and not as a direct consequence of the contact between the hot peridotite and the crust at lower pressure. In Massonne's (2014) interpretation, the peridotite is thus not responsible for partial melting in the crust. Barich (2016) has furthermore dated these garnets with the $\mathrm{Lu} / \mathrm{Hf}$ method and found only old ages from about $289 \mathrm{Ma}$ to $130 \mathrm{Ma}$. No Alpine ages are retrieved with that method in the Jubrique Unit. This inevitably leads to the question of the age of partial melting in general in this region. Is it all late Paleozoic or Mesozoic? This is the conclusion reached by Sánchez-Navas et al. (2017), Gómez-Pugnaire et al. (2019) and the same history was recently proposed by Rossetti et al. (2020) for the Beni Bousera peridotite envelope. In the end, the strongest observation supporting a Miocene partial melting event is the occurrence of late granitic dykes intruding both the peridotite and the crustal units documented by Sánchez-Rodríguez and Gebauer (2000) and Rossetti et al. (2010, 2013). Rossetti et al. (2010) favor the occurrence of two main partial melting events, one deep during the Paleozoic and one during the early Miocene at low pressure conditions, as constrained by the occurrence of magmatic andalusite in the Miocene products.

Based on a detailed structural study of the deformation gradient in the peridotite when approaching the BermejaJubrique Shear Zone and one-dimensional numerical modelling of the evolution of the dynamothermal aureole, Précigout et al. (2013) suggest that the deformation occurred between 30 and $22 \mathrm{Ma}$ from a depth of $\sim 18 \mathrm{~km}$, as indicated by the depth of formation of the aureole, before the final emplacement on top of the external zones. This leads Gueydan et al. (2019) to propose that the peridotite was exhumed in an OligoceneMiocene back-arc before it was obducted on top of the neighboring continental margin. In these latter works, the argument for a back-arc setting of the extensional BermejaJubrique Shear Zone is the high thermal gradient necessary to maintain high temperature at such a shallow depth.

The internal structure of the peridotite is an important constraint for this discussion. It is composed of four petrostructural domains (Fig. 11A) from northwest to southeast: garnet/spinel mylonite (Grt/Spl-mylonite), a spinel-tectonite (Spinel-t), a granular peridotite and a plagioclase tectonite. Here are their characteristic features:

- the Grt/Spl-mylonite is in direct contact with the Jubrique Unit. It corresponds to highly deformed spinel-bearing peridotites and garnet-bearing pyroxenite layers. Very locally along the contact, a few Grt-bearing peridotite can also be found; the best outcrops can be observed in the Beni Bousera peridotite in Morocco (Reuber et al., 1982; Saddiqi et al., 1988; Kornprobst et al., 1990). Overall, the stretching lineation is close to horizontal, while the foliation strikes NE-SW and dips steeply toward the 
NW $\left(60-80^{\circ}\right)$. All garnets are partially kelyphitized, i.e., surrounded by a symplectitic corona of very fine-grained, fibrous intergrowth of pyroxene and spinel \pm amphibole. These pseudomorphs have been produced during the breakdown of garnet and they do not show any trace of strain (Obata, 1980). At the extreme west of the Grt/Splmylonite, some pseudomorphs of graphitized diamonds have been also found (Pearson et al., 1989; Davies et al., 1993). Like the kelyphites, they are located in boudins of pyroxenites;

- the Spl-tectonite is part of a $\mathrm{km}$-scale shear zone that includes the (i) Grt/Spl-mylonite. It is also composed of Spl-bearing peridotite and Grt-bearing (with kelyphite) pyroxenite layers. The shear zone is characterized by continuous steeply-dipping foliation trajectories across the two domains and a strain gradient across strike (Précigout et al., 2007, 2013). Both the Grt/Spl mylonite and Spl tectonite are typical of lithospheric mantle deformation during cooling and decompression, from the garnet to the spinel stability fields (Garrido et al., 2011). They are also cross-cut by chromium-rich pyroxenites that are weakly folded during the formation of the foliation (Précigout et al., 2013), directly related to the partial melting that occurred in the granular peridotite, i.e. D-group from Garrido and Bodinier (1999);

- in the granular peridotite domain, no foliation is observed, and all grains are significantly larger than in the spinel tectonite. Most peridotites are lherzolite and harzburgite with Spl-bearing aluminous pyroxenite layers. The transition between the granular domain and spl tectonite, i.e., the so-called recrystallization front (van der Wal and Bodinier, 1996; Lenoir et al., 2001), slightly cross-cuts the foliation of the Spl-tectonite (Lenoir et al., 2001; Précigout et al., 2013) and three main features related to the foliation of the spinel tectonite are observed: (1) the recrystallization front follows the map-scale bending of the Spl-tectonite (Précigout et al., 2013), (2) isoclinal folds of aluminous pyroxenites have axial planes parallel to the foliation of the spl-tectonite, and (3) elongated spinel grains are parallel to the lineation of the spinel tectonite (van der Wal and Vissers, 1996). Altogether, these features indicate that the granular peridotite overprinted the $\mathrm{Spl}$ tectonite by progressive upward, porous-flow "asthenospherization". In contrast, Johanesen et al. (2014) provided evidence of deformed residual melt in the Spl tectonite (close to the front), which suggests instead that the tectonite overprinted the granular domain. Actually, all these features are consistent if melting and deformation in the Granular domain and tectonite were coeval. This interpretation is further supported by the slight folding and absence of transposition of the Cr-rich pyroxenites injected across the shear zone during partial melting in the granular domain (Précigout et al., 2013), which shows that partial melting in the granular domain was coeval (tardi-tectonic) with strain localization in the mantle lithosphere above;

- the Plagioclase-tectonite (in fact Spl-bearing peridotite with stretched coronas of plagioclase around spinels) domain affects the granular domain to the south with a penetrative foliation. Overall, the foliation strikes E-W, highly oblique on the Spl tectonite foliation (NE-SW), but the lineation/kinematics in the two domains are very close (top to the SW). There are also numerous folded pyroxenite layers with two families of folds, at metric scale, such as observed everywhere in the massif, and at hectometric scale. While meter-scale folds pre-date the formation of the Pl-tectonite (they are probably related to the deformation of the shear zone before partial melting of the granular peridotite), the axial plane of hectometric folds is parallel to the foliation plane of the Pl-tectonite. Two main features finally characterize the Pl-tectonite: (1) the presence of podiform chromite layers, also present further west in the Spl-tectonite and in other peridotite massifs. Some of these chromites contain zoned zircons with a large range of ages from the Precambrian to $20 \mathrm{Ma}$ (González-Jiménez et al., 2017), (2) the occurrence of ultramylonitic complexes nearby the granular domain (not at the base of the massif) and only observed at the extreme west of the Pl-tectonite domain (Hidas et al., 2013, 2015; Précigout et al., 2013).

\section{Tectono-metamorphic evolution, new observations}

New field observations and radiometric ages obtained in the framework of Eloïse Bessière's $\mathrm{PhD}$ (Bessière, 2019) in the Alpujárride Complex brings some of the answers and reopen some debates.

\subsection{Significance of the Ronda peridotites-Nieves Unit contact, thrust or extensional detachment?}

The geological map of Figure 11 shows that the western contact of the Ronda peridotite massif is continuous in space. However, the nature of the juxtaposed rocks in contact changes abruptly along strike. In the southwest, the peridotite is overlain by the Jubrique Unit, while in the northeast the peridotite lies with a steep contact next to the Nieves Unit (Dürr, 1963; Balanyá et al., 1997; Mazzoli and Martin-Algarra, 2011; Mazzoli et al., 2013), also referred in the literature as the Dorsale Calcaire (Fallot, 1937; Durand Delga and Foucault, 1967; Kornprobst and Durand-Delga, 1985; Chalouan et al., 2008). A detailed study of the latter contact shows that the orientation of stretching lineations and fold axes in the ductilely deformed marbles and recrystallized limestones and dolostones of the Nieves Unit are all parallel to the trace of the contact (Bessière, 2019) and not perpendicular as previously published (Mazzoli and Martin-Algarra, 2011; Mazzoli et al., 2013) (Fig. 11). Kinematic indicators suggest a left-lateral motion during ductile deformation, consistent with the leftlateral, top-to-the SW motion described along the JubriqueBermeja Shear Zone (Précigout et al., 2013; Johanesen and Platt, 2015). The contact between mantle rocks and marbles can be observed in several quarries where serpentinite and magnetite ore deposits have been exploited in the past (Bessière, 2019). The contact shows well-preserved ductile deformation with intense folding of the ore body with metamorphic olivine. The contact and its ductile deformation are thus preserved without significant brittle reactivation. The peridotite in these quarries is intensely serpentinized with local 

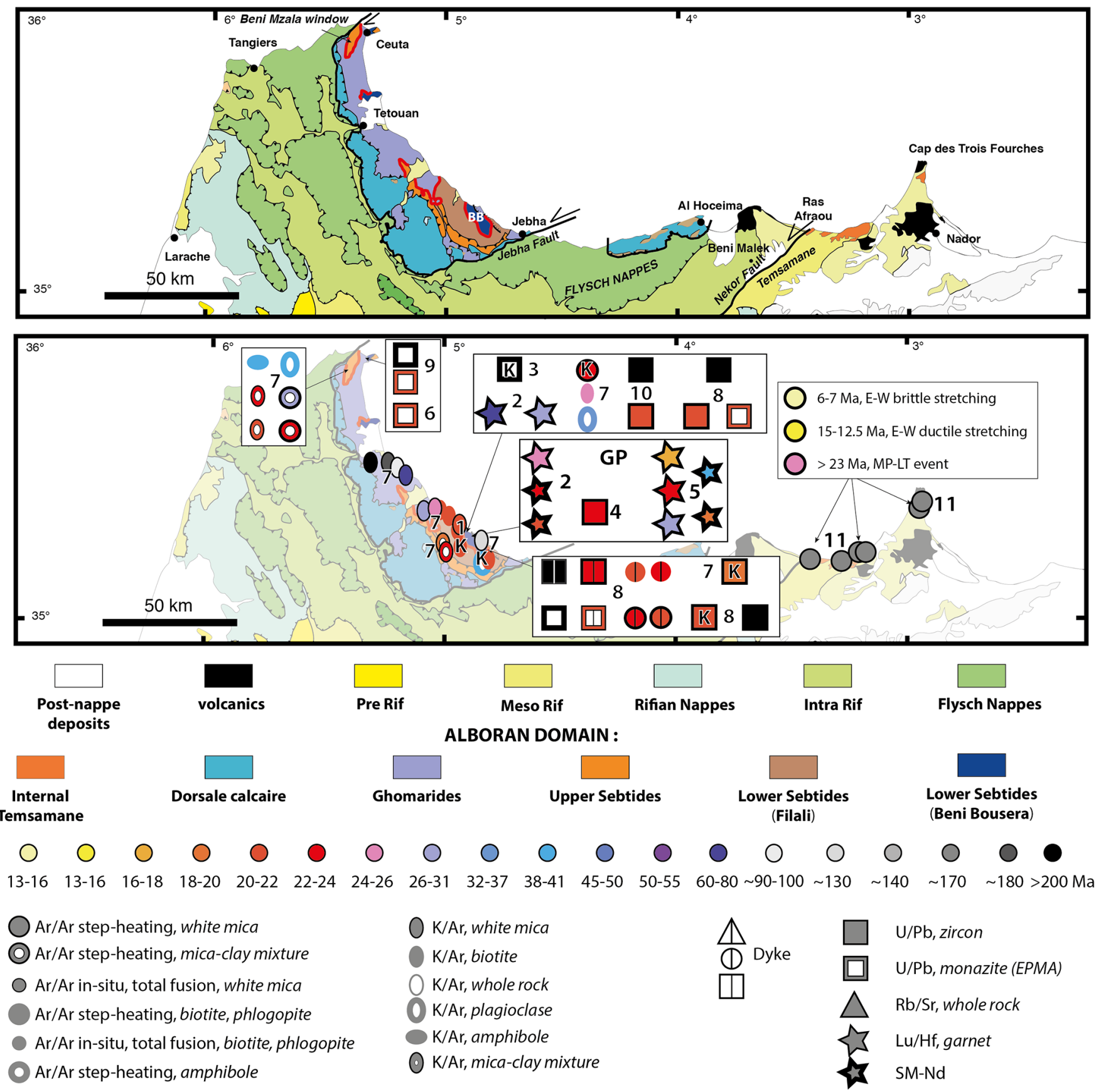

Fig. 10. Tectonic map of the Rif and available radiometric data. See Figure 3 for references. BB: Beni Bousera, GP: garnet-peridotite, $\mathrm{K}$ : kinzigites.

occurrence of ophicalcites. Bessière (2019) interprets all these observations as indicating a transition from ductile deformation at high temperature, to brittle deformation at low temperature, as indicated by the presence of ophicalcites, with pervasive fluid infiltration in a context of hyper-extension similar to the observations in exhumed ocean-continent transition or hyper-extended rifts in the Alps (Picazo et al., 2013) or the Pyrenees (Lagabrielle et al., 2019a, 2019b and references therein) as well as at present-day magma-poor Mid Oceanic Ridges (Picazo et al., 2012). Hyper-extension in such contexts is responsible for the exhumation of sub-continental mantle rocks during rifting and the interaction of the exhumed peridotites with sea water (Clerc et al., 2012, 2014, 2015; Lagabrielle et al., 2019a, 2019b). Raman spectrometry of carbonaceous material (RSCM) geothermometry (Beyssac et al., 2002; Lahfid et al., 2010) applied to an extensive sampling within the Nieves metamorphic succession (Bessière, 2019) allows mapping the steep $\mathrm{T}_{\max }$ gradient already documented along a section with classical metamorphic petrology tools by Mazzoli et al. (Mazzoli and Martin-Algarra, 
2011; Mazzoli et al., 2013). The map (Fig. 11A and B) shows an obliquity of isograds with respect to the peridotite-marble contact and $\mathrm{T}_{\max }$ at the contact decreases progressively toward the northeast from temperatures over $600^{\circ} \mathrm{C}$ in Jubrique Unit (Negro et al., 2006) to low temperature below $300^{\circ} \mathrm{C}$ in the Nieves Unit. These observations show that $T_{\max }$ within the metasediments of Nieves Unit and basement rocks of Jubrique Unit along the western contact of the peridotite regularly decrease from the Jubrique unit in the SW to northeastern part of the Nieves Unit, suggesting that this contact was once cutting down-section from the sedimentary cover down to the crust and finally the lithospheric mantle underneath. Bessière (2019) thus proposes a continuation of the extensional Bermeja-Jubrique Shear Zone toward the northeast along the peridotite-marbles contact (Fig. 12). This extensional shear zone cutting downsection would then correspond to a top-to-the southwest lowangle extensional shear zone, named the Nieves-Los Reales Detachment. In this interpretation, the Nieves Unit would represent the original sedimentary cover of Jubrique Unit. The top of Jubrique Unit shows Permo-Triassic phyllites, absent in Nieves Unit, and locally Triassic marbles, but the whole sequence is highly thinned and attenuated by late extensional faults (del Olmo Sanz et al., 1987; Balanyá et al., 1997). The Jubrique marbles then correspond to the lowermost part of the Triassic sequence (Dürr, 1963), highly attenuated by extension, which remained attached to the basement below a decollement, and the Nieves Unit the upper part of the Jubrique cover. The overall geometry can be described as a mantle core complex (Brun et al., 2018) similar to oceanic core complexes observed along slow mid-oceanic ridges with a downward-concave normal fault (MacLeod et al., 2009). It would have been rooted at depth as a steep-dipping ductile shear zone and gets flatter upsection while the footwall get exhumed into the brittle field (Lavier et al., 1999). It is noteworthy that such a crustal-scale structure juxtaposing continental rocks with exhumed mantle was also modeled and proposed by Brune et al. (2014) as the "exhumation channel", corresponding for these authors to the ultimate phase of asymmetric rifting before the onset of seafloor spreading.

Because the mineralization of ophicalcite and magnetite are still observable and almost undeformed in the brittle regime, Bessière (2019) argues that this contact has been sealed when the extensional event ended. The palaeo-thermal structure in the HT-metamorphism zone in the Nieves Unit showing an obliquity of isograds with the contact also reinforces our extensional emplacement model. The proposed extensional setting with mantle exhumation fits the observations of Pedrera et al. (2020) with sheared peridotite bodies embedded in Triassic sediments and is similar to what is generally expected from the pre-orogenic setting of the Betics corresponding to a former oblique and segmented system between the Central Atlantic and the Western Tethys (Leprêtre et al., 2018; Fernàndez et al., 2019; Angrand et al., 2020; Pedrera et al., 2020).

\subsection{New ${ }^{40} \mathrm{Ar} /{ }^{39} \mathrm{Ar}$ data in the peridotite-Nieves contact, significance of the ca. $20 \mathrm{Ma}$ event}

The observations summarized above lead us to discuss the significance of the ca. 20 Ma cluster of ages retrieved from all
Alpujárride units. It is sometimes interpreted as an intense thermal event that would have reset all isotopic systems, but the finding of this very same age also in units of the central and eastern Alpujárride Complex that did not see any high temperature excursion during the exhumation (Bessière, 2019, see below) however suggests that it may rather correspond to an exhumation age (cooling) than dating the peak of pressure.

Further west in the western Alpujárride Complex, these young ages are associated with rocks that have gone through HT-L $P$ facies, some of them partially molten. Granitic dykes and migmatite leucosomes yield the same age as well $(\mathrm{U} / \mathrm{Pb}$ on zircons). Platt and Whitehouse (1999) dated zircons from three samples along a transect from the western to the eastern Alpujárride Complex (Sierra Cabrera) taken from a high- $P$ garnet granulite, a cordierite granite, and a sillimanite Kfeldspar gneiss and they all give ages close to $20 \mathrm{Ma}$. Based on thermal modelling, the authors conclude that the whole Alpujárride Complex has been through a high-temperature event with a thermal peak around $27 \mathrm{Ma}$ and a subsequent exhumation, $20 \mathrm{Ma}$ recording the passage above some $16 \mathrm{~km}$.

As recalled above, the age of partial melting have been recently challenged by several authors based on $\mathrm{U} / \mathrm{Pb}$ ages on zircons obtained in the Betics and the Rif in the AlpujárrideSebtide Complex near the contact with the peridotite massifs (Zeck and Williams, 2001; Massonne, 2014; Acosta-Vigil et al., 2014; Barich, 2016; Sánchez-Navas et al., 2017; GómezPugnaire et al., 2019; Rossetti et al., 2020). If early Miocene ages are indeed found, many zircons yield late Paleozoic ages.

In order to obtain new age data on the age of the HT event in the Nieves Unit at the contact with the peridotite, we selected marbles containing metamorphic micas (phlogopite) and dated them with the ${ }^{40} \mathrm{Ar} r^{39} \mathrm{Ar}$ step-heating technique. Phlogopite is part of a single fresh HT paragenesis generally including calcite-dolomite + olivine + phlogopite + amphibole + magnetite and the samples escaped from any pervasive late low-temperature deformation and retrogression (Mazzoli et al., 2013; Bessière, 2019). The result in unequivocal, all samples yield homogeneous Ar release spectra at around $20 \mathrm{Ma}$ (Fig. 13), which is, within errors, very similar to most ages obtained in this region whatever the method used.

One additional important point to consider is the absence of any metamorphic recrystallization in the Nieves limestones at less than $3 \mathrm{~km}$ away from the contact with the peridotite, showing that the Nieves Unit has never been subducted to any significant depth (Bessière, 2019), in striking contrast with the Alpujárride units further east, where $\mathrm{H} P$-LT metamorphism is documented (Goffé et al., 1989; Azañón and Goffé, 1997; Booth-Rea et al., 2005). The maximum pressure indicated by the $\mathrm{H} T$ parageneses in the marbles is 3 kbar (Mazzoli and Martin-Algarra, 2011; Mazzoli et al., 2013), and the maximum burial is thus around $10 \mathrm{~km}$ assuming an average density for the continental crust. This shallow depth leads Mazzoli et al. (Mazzoli and Martin-Algarra, 2011; Mazzoli et al., 2013) to propose the intracrustal emplacement of the hot peridotite in contact with the underthrusted Nieves Unit at less than $10 \mathrm{~km}$ for a temperature of about $700^{\circ} \mathrm{C}$. This evidence also leads Gueydan et al. (2019) to propose a model of obduction of the continental margin of the Alboran back-arc basin on the Iberian passive margin that would be represented by the Nieves Unit or the Guadaiza Unit. It should be noted here that a 


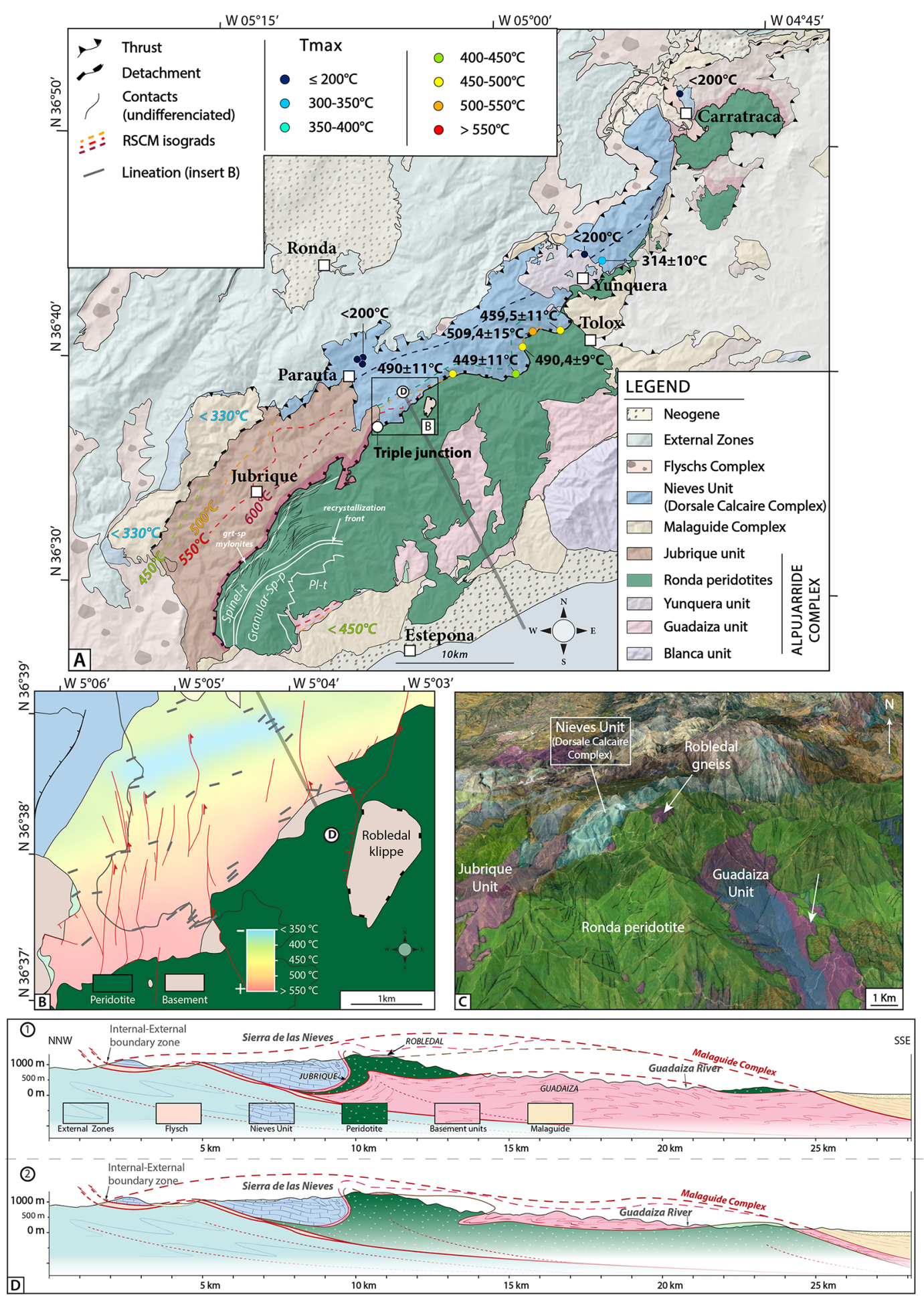

Fig. 11. Synthesis of the work of Bessière (2019) in the vicinity of the Ronda peridotite massif and its contact with the Nieves (Dorsale Calcaire) unit. A: General map of the Los Reales peridotite, Jubrique unit and Nieves unit. Isograds and characteristic temperatures are shown. Petrological and deformation domains in the peridotites are indicated in grey after Lenoir et al. (2001). Pl-t: plagioclase-tectonite, granular-sp-p: granular spinel peridotite, spinel-t: spinel tectonites, grt-sp mylonites: garnet-spinel mylonites. B: map of the triple junction between the peridotite, Jubrique unit and Nieves unit with stretching lineations and peak temperatures (RSCM method). C: 3D view of the same region draped on a Google Earth image showing the complexity of the geometry of the contact between the peridotite, Guadaiza unit and Jubrique unit. D: comparison of two end-member cross-sections with Guadaiza unit either underneath (Lundeen, 1978) or on top of the peridotite (Sanz de Galdeano, 2017). In the upper section Robledal and Jubrique units form a single entity while Guadaiza unit is a separate unit; in the lower section, Guadaiza, Robledal and Jubrique units are parts of a single unit. Caution: note that the western contact of the peridotite is decorated by indications of a detachment, which is our final interpretation at the time of formation of the Nieves-Los-Reales Shear Zone but the present-day position of the peridotite-Nieves contact is a steep fault putting the peridotite on top of Nieves Unit. 


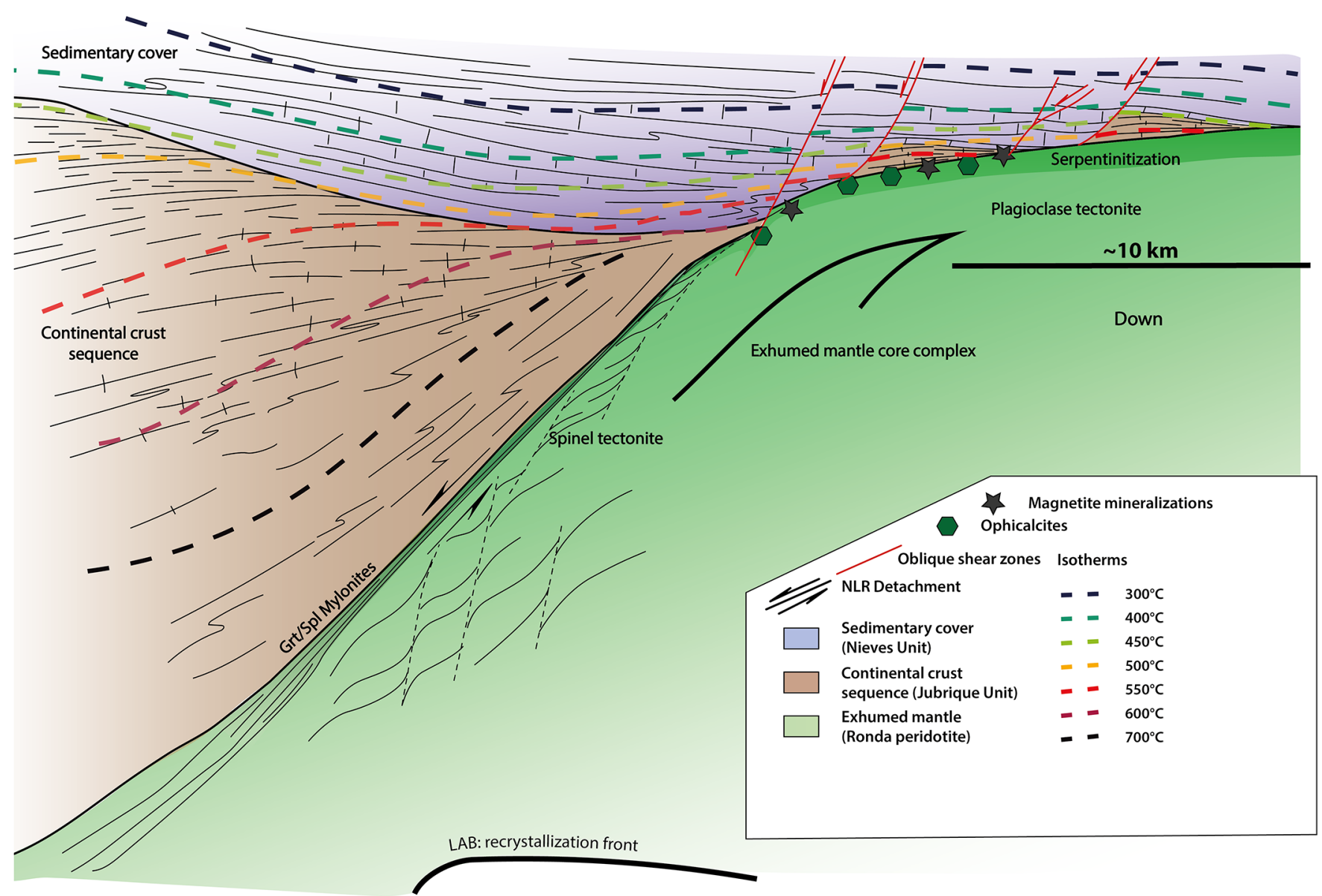

Fig. 12. Hypothetical reconstruction of the situation of the Los Reales-Nieves detachment at the time of extension and mantle exhumation after Bessière (2019).

temperature of $700^{\circ} \mathrm{C}$ at less than $10 \mathrm{~km}$ depth in an accretionary wedge or a subduction complex is twice as shallow as the low-temperature $\left(500-600^{\circ} \mathrm{C}\right)$ metamorphic sole below the Semail ophiolite in Oman (Agard et al., 2016; Soret et al., 2017). The back-arc setting of the obducted crust and the young age of the back-arc basin in the Alboran Domain may partly explain this exceptionally hot situation, but the Oman ophiolite was also young when it was obducted.

One important question is the significance of the dynamothermal aureole compared to the HT metamorphism in the Nieves unit near the contact with the peridotite. The "obduction" (Gueydan et al., 2019) and the "subduction channel" (Mazzoli and Martin-Algarra, 2011; Mazzoli et al., 2013) models implicitly assume that the basement units and the Nieves metasediments were both metamorphosed at the contact with the hot peridotite during its exhumation. However, the original paleogeographic situations before thrusting of the Nieves and Blanca Units are strikingly different, even more with the rest of the Alpujárride units. The Nieves Unit (Dorsale Calcaire) is sometimes considered as the former cover of the Malaguide Complex (Dürr, 1963; MartínAlgarra et al., 2004; Michard et al., 2002) or of the Sebtide Complex (Chalouan and Michard, 2004). In the hyperextension interpretation of Bessière (2019) (Fig. 12) it is considered the original cover of the Jubrique basement. The most important difference is moreover the much higher metamorphic pressure in Blanca Unit and Ojén eclogites compared to Nieves Unit. As mentioned above, the Nieves metasediments never experienced any pressure higher than $3 \mathrm{kbar}$ and the temperature at $1.5 \mathrm{~km}$ of the contact with the peridotite decreases very fast to less than $350{ }^{\circ} \mathrm{C}$. The Triassic metacarbonates at the top of Jubrique unit and the Nieves metacarbonates have never seen significant $\mathrm{H} P$-L $T$ conditions. The Ojén eclogite has instead recorded a pressure around 15$16 \mathrm{kbar}$, which suggests a depth of $\sim 45 \mathrm{~km}$ during subduction for a temperature of about $730{ }^{\circ} \mathrm{C}$ (Tubía and Gil Ibarguchi, 1991). The Nieves-Jubrique Triassic metasediments must have then been subducted much less than the Ojén eclogite. Available ages for the HT-LP metamorphism in the Ojén eclogite are around $20 \mathrm{Ma}$, including zircons dated with the $\mathrm{U} / \mathrm{Pb}$ method (Sánchez-Rodríguez and Gebauer, 2000). These ages do not however necessarily correspond to the peak of metamorphism. Kohn et al. (2015), based on thermodynamic calculations, show on which part of $P-T$ paths zircons crystallize or dissolve and they conclude that, in most situations, the crystallization of zircons does not correspond to the metamorphic peak, rather to exhumation (Fig. 14B). If one then considers that the dated zircons formed during the retrograde part of the $P-T$ path, especially in this case where the peak of temperature does not coincide with the peak of 


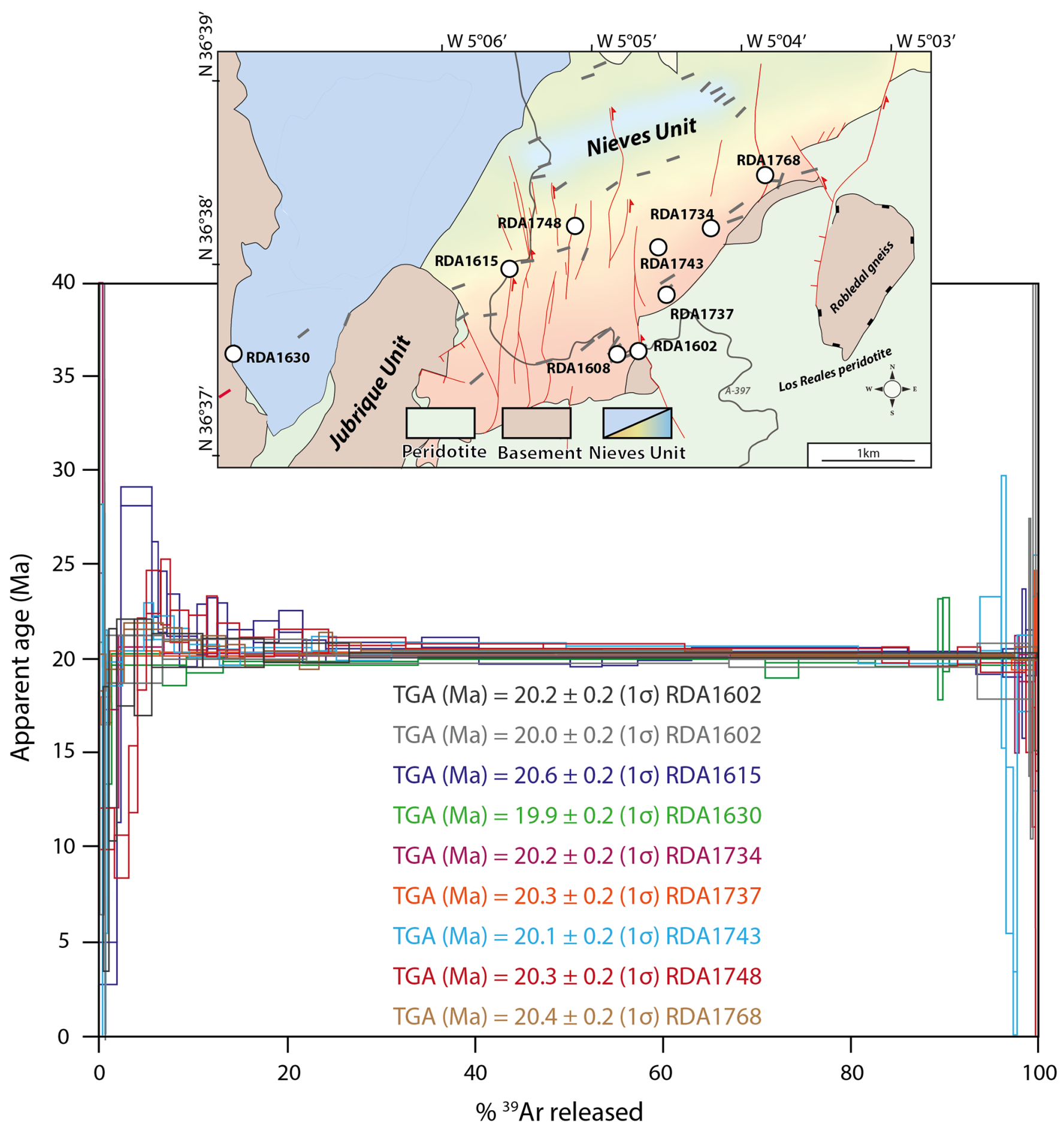

Fig. 13. New ${ }^{40} \mathrm{Ar} /{ }^{39} \mathrm{Ar}$ step-heating ages of phlogopites from marbles sampled near the contact with the peridotite. Data after Bessière (2019).

pressure, the age of the peak pressure is unknown but it has to be necessarily older than $20 \mathrm{Ma}$.

The interpretation of the Nieves-Los Reales shear zone as an extensional detachment exhuming the Ronda peridotite in a context of hyper-extension until shallow conditions and possibly until the sea bottom already in the Mesozoic requires a different interpretation of available ages. The absence of any
$\mathrm{H} P$-L $T$ parageneses in the Nieves metasediments precludes any deep subduction of this unit. Two solutions can then be envisaged. The first solution is the one put forward by Gueydan et al. (2019) and Précigout et al. (2013) proposing the overthrusting of a just-exhumed sub-continental lithosphere mantle (still hot) in the back-arc region, and in consequence still maintaining high temperatures. This solution fits the hot 

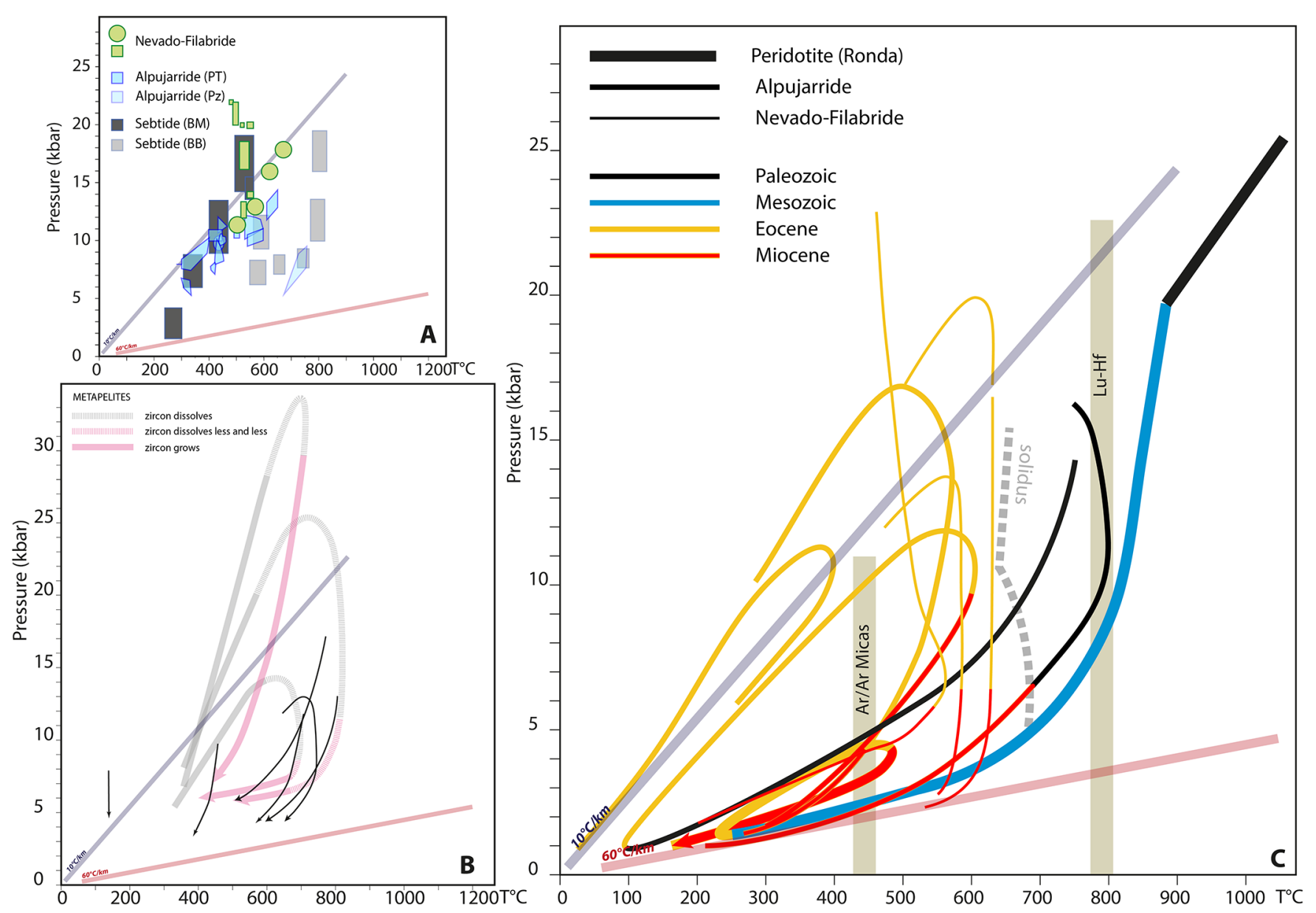

Fig. 14. Synthesis of the $P$-T-time evolution of the Internal zones of the Betic Cordilleras (Ronda peridotite, Alpurarride and Nevado-Filábride complexes). A: Peak-pressure conditions in the Alpujárride and Nevado-Filábride complexes. See references in the caption of figures 5 and 9. Green squares are from Santamaria-Lopez et al. (2019), Augier et al. (2005) and Li and Massonne (2018). Green circles represent the peak of $P$ - $T$ conditions on the $P-T$ paths proposed by Platt et al. (2006). Data for the Alpujárride are from Azañón et al. (1997, 1998) and Azañón and Crespo-Blanc (2000). Lighter colored domain is for the Paleozoic basement of Adra unit. Data for the Sebtide complex after Chalouan et al. (2008). BM: Beni Mzala antiform (Permo-Triassic units). BB: Beni Bousera antiform (Paleozoic units). PT: Permo-Triassic. Pz: Paleozoic. $\mathrm{B}$ : discussion on the ages of zircons obtained with $\mathrm{U}-\mathrm{Pb}$ method showing some representative $P-T$ paths taken from the Alpujarride complex (see figure 5) and the synthetic $P$-T paths of Kohn et al. (2015) with the parts where zircons crystallize or dissolve. Black lines represents a selection of retrograde P-T paths from the Alpujárride-Sebtide Complex. C: interpretation of the $P$-T-time paths of all three domains. The different line thicknesses represent the Ronda peridotite, Alpujárride and Nevado-Filábride complexes and the different colors stand for ages along the $P$ - $T$ paths.

conditions at the base of the peridotite and the clustering of ages around $20 \mathrm{Ma}$. It does not however easily explain the presence of ophicalcite and magnetite ore bodies that form at low temperature in the presence of large amounts of water along the contact between the peridotite and the Nieves marbles. It would be possible only after overthrusting and cooling of the peridotite. Moreover, placing the HT-LP metamorphism and coeval extensional deformation in the back-arc domain during the Oligocene and Miocene, as in Garrido et al. (2011), Précigout et al. (2013) or Gueydan et al. (2019), implies that the extensional deformation came after an episode of crustal thickening and that the HT-LP metamorphism is a regional event. However, the section observed west of the Sierra Bermeja does not show any repetition of stratigraphy or crustal sequences. It instead shows the Mesozoic cover deposits, whose upper part is devoid of any significant metamorphism at a short distance from the contact, in direct contact with either the peridotite or the attenuated basement of Jubrique Unit. It thus shows that the extensional deformation did not affect a previously thickened crust and that the observed metamorphism cannot be a regional event, as also shown by the steep temperature gradient west of the contact with the peridotite. The exhumation of the hot peridotite up to close contact with the sedimentary cover has to be a direct consequence of extension. One additional problem with the Miocene extension model is the absence of deep Miocene synrift sediments on top of the peridotite. Although the comparison is not straightforward, one can compare the setting proposed by Précigout et al. (2013) with similar cases in the Mediterranean realm. The closest cases are the southern Tyrrhenian Sea or the Gulf of Lion where mantle has been exhumed during rifting (Jolivet et al., 2015; Prada et al., 2016). In both cases the exhumed mantle is covered with early Miocene or Pliocene syn-rift sediments deposited in an open 
marine environment, at significant depth, which are not described in the Betics above the peridotite.

The second solution is then to consider that the peridotite had been exhumed much earlier during the Mesozoic up to the surface or the sea bottom, as envisaged in van Hinsbergen et al. (2014) or Pedrera et al. (2020), thus explaining the progressive decrease of temperature along the contact and the formation of ophicalcites. This exhumed peridotite together with the Jubrique Unit and its cover (Nieves unit) would then have been buried to middle crustal conditions during the Mesozoic by sedimentation above and then involved in the fast overthrusting event and exhumed at $\sim 20 \mathrm{Ma}$. The ca. $20 \mathrm{Ma}$ ages we obtained from phlogopite in the marbles would reflect this late episode. This interpretation of a major exhumation episode at about $20 \mathrm{Ma}$ can explain why it is recorded also during late deformation stages in tectonic units that have never seen any high-temperature overprint in the Central and Eastern Alpujárride Complex. Further studies should focus on this question to see whether this early exhumation model can fit observations within the peridotite such as the succession of petro-structural domains and the formation of the plagioclase tectonite and dynamothermal aureole. This interpretation also involves a minor pressure increase before exhumation at $20 \mathrm{Ma}$, which is not recorded in the available P-T paths of the Ronda peridotite and Jubrique Unit (Garrido et al., 2011; Balanyá et al., 1997).

\subsection{Age of the HP-LT event in the Alpujarride and Nevado-Filábride Complexes}

In order to improve the data set on the age of the HP-LT event in the Alpujárride Complex, Bessière (2019) has sampled the units where the Alpine $\mathrm{H} P$-LT parageneses are best preserved, namely the Salobreña unit, for dating white micas with the step-heating ${ }^{40} \mathrm{Ar} /{ }^{39} \mathrm{Ar}$ method. Platt et al. (2005) have obtained one in situ ${ }^{40} \mathrm{Ar} /{ }^{39} \mathrm{Ar}$ Eocene age $(\sim 48 \mathrm{Ma})$ in one sample from Sierra Alhamilla and a series of younger ages until the Miocene. They discuss the validity of older ages in their paper in terms of argon loss/excess and resetting of the K/Ar system by various processes such as deformation or fluid circulation. They also dated some Paleozoic protoliths from the Castro slice in the Alpujárride Complex (Sierra Alhamilla) and as a clear Variscan metamorphic inheritance is now proven in these Paleozoic sections (Gómez-Pugnaire et al., 2019), old ages may simply reflect isotopic inheritance of incompletely reset white micas. In order to reassess the timing of the HP-LT metamorphism in the Alpujárride Complex, Bessière (2019) sampled again the post-Paleozoic sediments to avoid any possible mélange ages (samples marked B in Fig. 8). The best preserved rocks still containing Fe-Mg carpholite are found at the western end of the Sierra Nevada, near Trevenque (Azañón and Goffé, 1997). Other samples were taken in different sites where the HP-LT parageneses were in different states of preservation (Fig. 8). Special attention was given to samples with different generations of micas clearly attributed to the HP-LT stage or the retrogression stage. In this regard, micas were dated from the bulk rock and from post-H $P$ veins. The micas growing at the expense of Fe-Mg-carpholite in the best preserved parageneses return quasi-plateaus around $38 \mathrm{Ma}$.
Other samples yield either plateaus or staircase spectra climbing from 20 to $38 \mathrm{Ma}$. Micas from the veins give plateaus at $20 \mathrm{Ma}$ showing that this age clearly records the crossing of the closure temperature of white micas along the exhumation path, during or after the formation of the veins and the crystallization of micas in those veins. This data sets shows that the HP-LT event in the Alpujárride Complex is at least 38 Ma old, confirming the ages obtained by Platt et al. (2005) and that the age around $20 \mathrm{Ma}$ records a later deformation event at lower pressure, coeval with vein formation. Staircase spectra are found in samples that were partially reset during exhumation. This sampling strategy thus shows that (1) the 20 Ma event is indeed recorded in all Alpujárride units, even those not affected by any thermal overprint and (2) that the HP-LT episode is Eocene in age, at least $38 \mathrm{Ma}$ old. This estimate is close to the $40 \mathrm{Ma}$ age recently obtained on monazite with the microprobe $\mathrm{U} / \mathrm{Pb}$ method from the Nevado-Filábride Complex (Li and Massonne, 2018) and are compatible with the ${ }^{40} \mathrm{Ar} /{ }^{39} \mathrm{Ar}$ ages obtained by Augier et al. (2005b) in the Nevado-Filábride Complex, suggesting that both the Alpujárride and the Nevado-Filábride Complexes experienced peak-pressure conditions during the Eocene. Consequently, the recent $\mathrm{U} / \mathrm{Pb}$ zircon and the garnet/clinopyroxene $\mathrm{Lu} / \mathrm{Hf}$ ages found in the Nevado-Filábride and interpreted as dating the peak of pressure in these units (López Sánchez-Vizcaíno et al., 2001; Platt et al., 2006) would in that case represent a later event, coeval with some exhumation increments of the complex.

\section{Synthesis and 3-D tectonic evolution}

This review emphasizes a number of first-order questions and recent new results that we now attempt to integrate in a synthetic model of the 3D evolution of the Betics and the Rif. We now summarize the main observations in terms of geometry, paleogeography, $P-T$ paths and timing.

\subsection{Paleogeography}

The classical division of the Alboran Domain in three main nappes, the Malaguides/Ghomarides, Alpujárride/Sebtides and Nevado-Filábride Complexes was mainly based on lithostratigraphic differences and abnormal stratigraphic superpositions (Egeler and Simon, 1969; Aldaya and García-Dueñas, 1976; Didon and García-Dueñas, 1976; García-Dueñas and NavarroVila, 1976; Simon et al., 1976; Torres-Roldán, 1979). The firstorder paleogeographic characteristics of the main domains were recognized early but further important discoveries came later. The presence of $\mathrm{H} P$-LT parageneses was initially restricted to the Nevado-Filábride Complex or to parts of the so-called Ballabona-Cucharon unit that was later divided between the Alpujárride and the Nevado-Filábride Complexes (Egeler, 1963; Nijhuis, 1964; Bakker et al., 1989; Weijermars, 1991; De Jong, 1993). The finding of Fe-Mg-carpholite in the Alpujárride Complex and the contrasted evolutions of the various Alpujárride units were spotted only later (Goffé et al., 1989; Bouybaouene et al., 1995; Vidal et al., 1999; Azañón and Goffé, 1997). Then, the paleogeographic affinity of the oceanic protolith of the Bédar-Macael unit is radically different from that of the continental Calar Alto and Ragua units within 


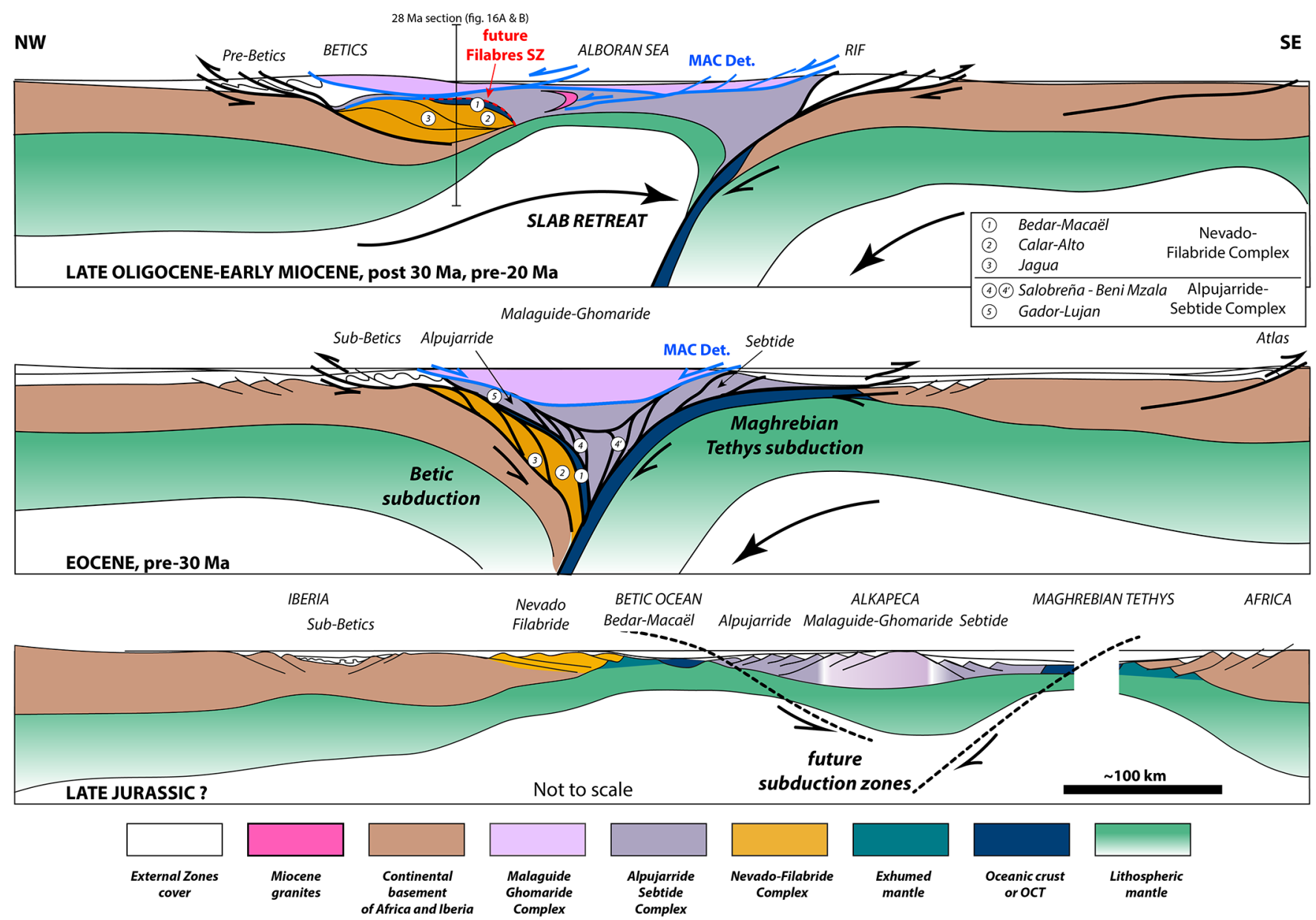

Fig. 15. Pre-20 Ma hypothetical reconstructions along a NW-SE profile of the evolution of the Betic Cordillera and the Rif from the Mesozoic to the Early Miocene. Note that these sections are schematic and that a component of shortening must be taken into account perpendicular to them during slab retreat.

the Nevado-Filábride Complex. Although Santamaria-Lopez et al. (2019) report close eclogite-facies peak metamorphic conditions in the three units, the lithological nature of Bédar Macael with marbles, metabasites and ultramafic rocks ascertains a different initial paleogeographic context, as already proposed by Puga et al. $(1995,1999,2002)$ or Michard et al. (2002) (Fig. 15). The initial inclusion of the Bédar Macael unit within the Nevado-Filábride Complex is mainly the consequence of a significant difference in terms of metamorphic grade (eclogite-facies) compared to the overlying Alpujárride Complex where HP-LT metamorphism was not yet described. It also corresponds to the localization of the main extensional shear zones, with the Filabres shear zone between the Alpujárride and the Nevado-Filábride Complexes (Platt and Vissers, 1989; García-Dueñas et al., 1992; Jabaloy et al., 1993; Martínez-Martínez et al., 2002, 2004). The works of Augier et al. (2005b) and Santamaria-Lopez et al. (2019) show that the whole Nevado-Filábride Complex went through a subduction history with similar $P$ - $T$-time evolution. But the initial contact between Bédar-Macael and Calar Alto units has to be a thrust putting some oceanic material or better an oceancontinent transition on top of continental units belonging to the Iberian margin. If we consider the most recent reevaluation of peak $P-T$ conditions in the Nevado-Filábride Complex by Santamaria-Lopez et al. (2019), the recorded $P$ - $T$ evolution of all three units is quite similar, suggesting that this superposition was an early event, before deep subduction. An alternative solution is that the three units were subducted sequentially and reached the same maximum pressure. So, assuming that the Bédar Macael unit was a partially oceanized domain or a continent-ocean transition zone with metabasites, marbles and continental rocks between the passive margin of the Alboran block and the Iberian margin (Puga et al., 1995, 1999, 2002; Michard et al., 2002) one should then clearly differentiate at least four domains: (1) the Malaguide-Ghomaride, (2) the Alpujárride-Sebtide, (3) the Bédar-Macael and (4) the Calar Alto/Ragua domains.

Within the Alpujárride-Sebtide Complex, the significance of the Ronda and Beni Bousera peridotite massifs should also be discussed, but there is less certainty concerning the paleogeographic position of these exhumed mantle units. As discussed above, two main interpretations have been proposed for extensional deformation responsible for mantle exhumation. The first interpretation is that the subcontinental mantle was mainly exhumed from large depths by extension within the back-arc domain during the Oligocene (Garrido et al., 2011; 
Précigout et al., 2013; Frasca et al., 2016; Gueydan et al., 2019) and soon later obducted on the margin of Iberia, together with the associated lower crustal units. The second interpretation is that the mantle was exhumed up to upper crustal conditions much earlier in the Mesozoic or even the late Paleozoic (Kornprobst and Vielzeuf, 1984; Michard et al., 1991; Sánchez-Rodríguez and Gebauer, 2000; van Hinsbergen et al., 2014; Bessière, 2019; Rossetti et al., 2020; Pedrera et al., 2020). In the latter situation, the region where the mantle has been exhumed would be a part of the wide hyper-extended domain between Africa and Iberia, or between a proto-Alboran block and Iberia. Recent studies in the Rif have shown the presence of small basins with exhumed mantle and minor mafic magmatism (Michard et al., 2014; Leprêtre et al., 2018; Gimeno-Vives et al., 2019). These hyper-extended basins would belong to the suite of Mesozoic rift basins around or within Iberia, from the Pyrenees, the Cantabrian range, the Galicia passive margin, the Columbretes basin, and the Maestrat and Cameros basins (Boillot et al., 1988; Roca and Guimerà, 1992; Salas and Casas, 1993; Salas et al., 2001; Lagabrielle and Bodinier, 2008; Etheve et al., 2018; Asti et al., 2019; Gimeno-Vives et al., 2019; Rat et al., 2019). In this context the Bédar-Macael Unit could also belong to the same group of basins.

The first interpretation fits well the high-temperature associated with the late emplacement if the Early Miocene age really represents the age of emplacement and thermal peak in the dynamothermal aureole. The second interpretation better explains the lack of significant metamorphism in the Nieves Mesozoic sediments at a short distance from the contact with the peridotite and the observation of ophicalcites along the contact. This second interpretation requires that the Miocene clustering of radiometric ages mainly represents an exhumation event and not the peak of temperature.

\subsection{Timing of tectonic and metamorphic events}

Before moving to reconstructions, we need a further discussion of the significance of radiometric ages and of the tectonic timing of the Betic-Rif Cordillera.

\subsubsection{Age and P-T conditions of the HP-LT event}

As discussed above, recent observations suggest that the subduction zone metamorphism in both the Alpujárride and Nevado-Filábride Complexes was reached in the Eocene. Consistent ages around $40 \mathrm{Ma}$ have been obtained with complementary methods with ${ }^{40} \mathrm{Ar} /{ }^{39} \mathrm{Ar}$ on white micas in the best preserved $\mathrm{H} P$-LT parageneses of the Alpujárride Complex (Bessière, 2019) and with microprobe U-Th- $\mathrm{Pb}$ on monazite dating in the eclogite of the Nevado-Filábride Complex (Li and Massonne, 2018). This observation is well in line with the very similar $P-T$ gradient in the two complexes. Figure 14A shows the compilation of published peak pressure conditions in the Alpujárride Complex (excluding basement lithologies) and the Nevado-Filábride Complex. All data cluster along the same $10{ }^{\circ} \mathrm{C} / \mathrm{km}$ gradient, the Nevado-Filábride Complex only reaching higher pressure than the Alpujárride Complex. This fits the simple model of a steady-state accretionary wedge or subduction channel, the best example being the Western Alps where all tectonic units recording peaks of metamorphism with different ages are aligned on a single straight line indicating a gradient of $\sim 8^{\circ} \mathrm{C} / \mathrm{km}$. This suggests that the same geodynamic context of a subduction channel has been maintained during the whole history of the Internal Zones (Jolivet et al., 2003; Agard et al., 2009). One additional argument against a middle Miocene subduction of the Nevado-Filábride Complex is the complete absence of any Oligocene or Miocene flysch-type sediments between the Nevado-Filábride nappes and the overlying Alpujárride Complex. Had the Nevado-Filábride Complex been subducted in the Middle Miocene, flysch or molasse-type sediments would have been deposited in the trench or foreland basin, like can easily be observed in the Alps below the major thrust contacts for instance.

The main difference among the different $P-T$ paths obtained in the Alpujárride and Sebtide Complexes is observed for the retrograde evolution, with $L P-H T$ conditions reaching anatexy in the Western Alpujárride Complex compared with the cold retrograde paths of the central and eastern Alpujárride Complex or the Beni Mzala unit in the Sebtide Complex. Compared with other back-arc contexts such as the Aegean or Tyrrhenian regions (Jolivet et al., 1998; Jolivet and Brun, 2010) this difference suggests that the units containing the best preserved HP-LT parageneses with Fe-Mg-carpholite have been exhumed earlier than the "hot" units and have thus escaped from the late HT event. The same difference can be observed in the Aegean between the blueschists and eclogites of Syros and Sifnos islands on the one hand and the migmatites of Paros and Naxos islands, on the other hand (Jolivet and Brun, 2010). The better preservation of HP-LT parageneses in the central and eastern Alpujárride Complex indeed suggests that these tectonic units were exhumed earlier than the western Alpujárride Complex. Very little information is known on the age of peak pressure in the west. It must be older than the $27 \mathrm{Ma}$ proposed for the beginning of extension in the Alboran basin (Platt et al., 1998; Platt and Whitehouse, 1999). This fits the ca. $34 \mathrm{Ma}$ age proposed by Massonne (2014). Apart from a $40 \mathrm{Ma}$ old $\mathrm{K}-\mathrm{Ar}$ ages on amphibole and plagioclase (Michard et al., 2006) (Fig. 10) from the Beni Mzala antiform, no Eocene ages are as yet available in the western part of the Rif. They were then extracted from the subduction channel soon enough to be protected from the HT evolution coeval with fast slab retreat after $20 \mathrm{Ma}$. The geometrical relations between the central and western Alpujárride are unknown, as the contact is hidden below the Malaguide Complex, but this discussion suggests that the Western Alpujárride units were extracted from below the Central Alpujárride units during extension after $27 \mathrm{Ma}$. They were initially below the central Alpujárride Complex because they were subducted later also. The age of $\mathrm{H} P$ LT metamorphism in Jubrique unit proposed around 34 Ma by Massonne (2014) is compatible with this hypothesis but the error bar on this age is still quite large. Further exploring this hypothesis would require a precise reconstruction of the geometry before the Miocene low-angle normal faulting that dissected the Alpujárride nappe stack and further dating campaigns.

\subsubsection{Significance of the ca. $20 \mathrm{Ma}$ event, regional exhumation versus thermal pulse}

In the hypothesis of a common peak of pressure in the Nevado-Filábride and Alpujárride Complexes during the Eocene as proposed above, the significance of the younger 

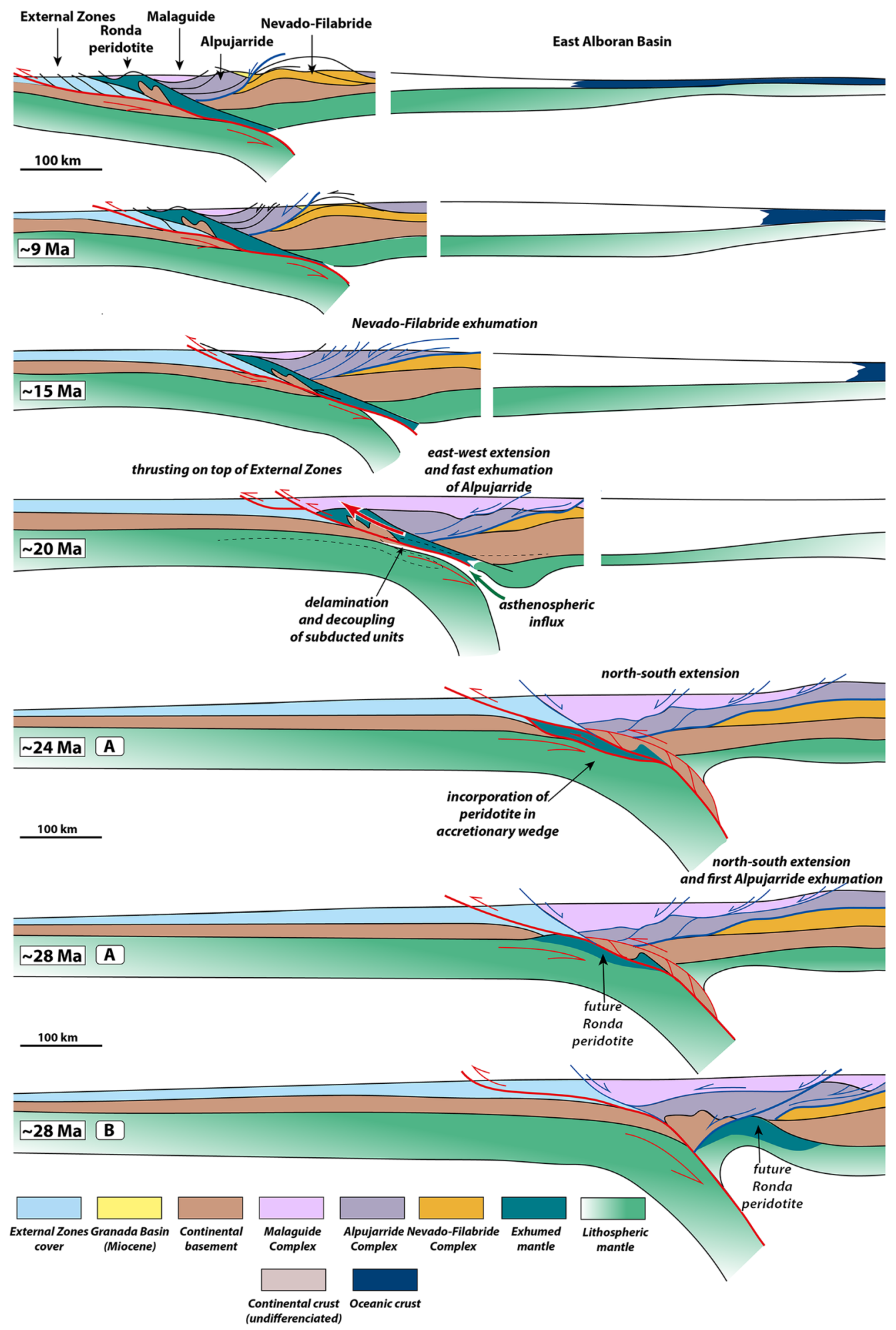

Fig. 16. Reconstructions along an E-W profile of the evolution of the Betic Cordillera from 28 Ma to the Present. The two 28 Ma stages represent two contrasted interpretations of the initial position of the Ronda peridotites, as discussed in text, as a piece of subcontinental mantle exhumed either during the Mesozoic rifting (interpretation B) or during the Oligo-Miocene back-arc extension (interpretation A). The 24 Ma stage incorporates interpretation A. During the later evolution (20 Ma stage) the slab of detached peridotite overthrusts the rifted basement situated further west and drags a piece of this basement underneath. At $20 \mathrm{Ma}$ the subducting slab is also delaminated, or detached, triggering an influx of hot asthenospheric mantle below the thick crust, making its exhumation easy and leading to an episode of HT-L $P$ metamorphism and anatexy. The entire Betic-Rif internal zones are exhumed at this stage. During the westward migration of the Alboran domain the crust in the back-arc region thins, breaks and is replaced by the oceanic crust of the Algerian Basin. 
ages, especially the cluster around $20 \mathrm{Ma}$, must be discussed further.

The young ages obtained in the Nevado-Filábride Complex with the $\mathrm{U} / \mathrm{Pb}$ method on zircon have to be the record of the late evolution during the exhumation of the complex along the retrograde path, following the hypothesis of the crystallization of zircon along the retrograde path discussed in Section 4.3 (Kohn et al., 2015). Figure 14B shows some representative $P-T$ paths of the Alpujarride Complex and the $P-T$ paths studied by Kohn et al. (2015) in metapelites. These authors question the interpretation of $\mathrm{U} / \mathrm{Pb}$ ages from zircons as the peak of pressure. They instead show that in most cases zircon growth corresponds to the retrograde path. One may then consider that the $\mathrm{U} / \mathrm{Pb}$ ages obtained on zircons in the Nevado-Filábride Complex (López Sánchez-Vizcaíno et al., 2001) do not correspond to the peak of pressure but to the later exhumation of these units. Similarly the middle Miocene Lu/Hf ages garnet-clinopyroxene obtained by Platt et al. (2006) could correspond to late exhumation ages owing to the small size of garnet grains (Scherer et al., 2000).

As seen above, the Early Miocene record is observed in rocks that have followed a path going through hightemperature conditions and rocks that have never seen any reheating nor followed any course through the amphibolitefacies or even less in the field of anatexy. This suggests that for such rock units, 20 Ma must be the record of cooling below the closure temperature of the ${ }^{40} \mathrm{Ar} /{ }^{39} \mathrm{Ar}$ system in white micas. This in turns shows an exhumation event at this period and then poses the same question for other rock units. As discussed in Platt and Whitehouse (1999), the age of the peak of temperature and pressure is older than $20 \mathrm{Ma}$ and they propose a date around $27 \mathrm{Ma}$ based on 1D thermal modelling. The same can be applied to all other ages. However, the $24 \mathrm{Ma}$ age obtained with the Lu/Hf method on the Beni Bousera peridotite by Pearson and Nowell (2004) suggests that part of the Beni Bousera peridotite was exhumed through the $800^{\circ} \mathrm{C}$ isotherm some $24 \mathrm{Ma}$ ago, which is not far from the $22-19 \mathrm{Ma}$ range, given the classical closure temperature proposed for the Lu-Hf system.

The same can be said for the $20 \mathrm{Ma}$ age we obtained in the Nieves marbles close to the contact with the peridotite. These rocks have recorded high-temperature conditions, much higher than the closure temperature of the K/Ar isotopic system in micas. The closure temperature for phlogopite is not precisely constrained, but it can be grossly estimated using the diffusion parameters of Hofmann et al. (1974) that depend upon grain size; for a radius of $500 \mu \mathrm{m}$, a closure temperature around 450 $500{ }^{\circ} \mathrm{C}$ seems a reasonable value. Given the $600{ }^{\circ} \mathrm{C}$ recorded by marbles close to the contact estimated on the basis of metamorphic parageneses (Mazzoli and Martin-Algarra, 2011; Mazzoli et al., 2013) and RSCM geothermometry (Beyssac et al., 2002; Lahfid et al., 2010; Bessière, 2019), the ca. $20 \mathrm{Ma}$ age can only represent a cooling age, not a crystallization age for the dated phlogopite grains. The close similarity between the nine ages obtained in this study is also an indication that the $20 \mathrm{Ma}$ age dates exhumation. This interpretation then means that the age of crystallization of those phlogopites is not known but also that the rock was stored at depth above the temperature of $450-500^{\circ} \mathrm{C}$ before $20 \mathrm{Ma}$. If the Nieves-Los Reales detachment were an Oligocene structure, then extension could be placed just before the late overthrusting that has exhumed the peridotite and the Nieves Unit up to the upper crust. In the opposite case of the Nieves-Los Reales detachment being a Mesozoic structure, the peridotite and the Jubrique-Nieves hangingwall of the detachment must have been subducted down to a shallow depth to be above this closure temperature but not deep enough to show any significant metamorphic recrystallization in the Mesozoic deposits at a short distance from the contact.

\subsection{Synthesis on the main steps and key constraints on timing}

One of the main controversial questions pertains to the age of the partial melting in basement units of the Alpujárride Complex. The recent works of Massonne (2014) and Barich (Barich et al., 2014; Barich, 2016) clearly show that a large part if not all the partial melting in the Jubrique Unit must be Permian in age. The same conclusion is reached by Rossetti et al. (2020) for the anatectic granulites forming the inner envelope of the Beni Bousera peridotite. The Miocene ages obtained on zircons or monazites in the same regions thus correspond to a second melting event or to a late exhumation (see also Rossetti et al., 2010). Jurassic and Early Cretaceous ages are found in the Jubrique Unit on zircon rims (Barich, 2016) and in the peridotite on pyroxenites (Sánchez-Rodríguez and Gebauer, 2000) suggesting that some exhumation either of the mantle or the lower crustal rocks also occurred at that time.

Some partial melting must have however occurred in the early Miocene as shown by the ages of zircons from late granitic dykes crossing the peridotites and their host rocks in both the Betics and the Rif (Sánchez-Rodríguez and Gebauer, 2000; Esteban et al., 2011; Rossetti et al., 2010, 2013). These ages suggest that, at least, parts of the crust were molten underneath the peridotite in the early Miocene like in the offshore domain of the Alboran Domain (Platt et al., 1998; Soto and Platt, 1999).

The timing of exhumation of the sub-continental mantle peridotite can be further discussed in this context and several options are possible with the existing data set. The intensity of early thinning is attested by the very thin layer of peridotite between the paleo-Moho (contact with Jubrique Unit) and the LAB (recrystallization front), the continuous structures from the granular domain to the Grt/Spl mylonite and Jubrique Unit, and coeval deformation and partial melting in the peridotite suggesting hyper-extension of a continental lithosphere. Ages of zircons in aluminous pyroxenites suggest that a part of this extension occurred over Mesozoic times, from $\sim 180 \mathrm{Ma}$ to $\sim 130 \mathrm{Ma}$ (Sánchez-Rodríguez and Gebauer, 2000), reflecting the rifting of the Alpine Tethys. Furthermore, the preservation of the granular domain suggests that this extension has been aborted at one point, promoting fast thermal rebalancing of the lithosphere. Yet, it is not clear how much of this extension was achieved during the late Paleozoic rifting episode. A part of the data set suggests that a significant part of the exhumation is related to a late Paleozoic extension. The strong thinning and the anatexy in high-temperature gneiss just above the peridotite in Beni Bousera and Ronda in the Jubrique unit are associated with late Paleozoic ages, suggesting that a first stage of exhumation was coeval with the post-orogenic evolution of the Variscan belt (Gómez-Pugnaire et al., 2019; 
Rossetti et al., 2020). However, most ages in zircons of aluminous pyroxenite layers in the Ronda peridotite indicate either Jurassic or Miocene times, which does not seem to support a significant phase of crustal thinning and related mafic intrusion during post-orogenic collapse of the Hercynian belt. Further investigations should then concentrate also on this question: why is the late Paleozoic crustal thinning recorded in crustal units not shown by the peridotite bodies?

Indeed, when the early rift aborted, the peridotites of the granular domain were still in the spinel stability field, which means that at least $30 \mathrm{~km}$ of rocks were above the recrystallization front at that time. The pressure of the recrystallization front has been estimated to $15 \mathrm{kbar} / 45 \mathrm{~km}$ (Garrido et al., 2011). The maximum thickness of the peridotite above the recrystallization front is about $10 \mathrm{~km}$, which leaves about $20 \mathrm{~km}$ for the continental crust, including the basement and the sediments. The lid of peridotite above the recrystallization front at present is not thick, $10 \mathrm{~km}$ is a maximum. This situation results from intense thinning during the whole exhumation process. A shown in Figure 12, the geometry and kinematics of a mantle core complex can account for this present-day situation. The exhumation of the mantle below a downward-concave normal fault progressively thins the crust and the lithospheric mantle reducing the distance between the different domains of the peridotite, once further apart. It is thus conceivable that the peridotite has been largely exhumed already during the Paleozoic and then the Mesozoic.

The plagioclase tectonite (Obata, 1980; Garrido et al., 2011) requires a subsequent deformation event, which also occurred during decompression into the plagioclase stability field with heating from below. The age of this event can also be debated, but it necessarily post-dates the "quenching" of the granular peridotite, and hence, it post-dates the deformation in the Spl-tectonite and Grt/Spl-mylonite (van der Wal and Vissers, 1996). One can first assume that it corresponds to a much more recent extensional event, which would go back to the Oligocene or early Miocene (Précigout et al., 2013; Frasca et al., 2017; Gueydan et al., 2019). This event produced the plagioclase tectonite with a temperature high enough to promote viscous flow of mantle rocks in the deep sequence. It also promoted deeper partial melting, as deduced by the injections of podiform chromitites. Above the plagioclase tectonite, the temperature was lower and the peridotites were not able to deform viscously. This may account for the absence of Pl-related deformation above the granular peridotite, but the temperature was still high enough to promote the breakdown of garnets that partially turned into kelyphite (statically). The ultramylonites could also serve as a benchmark to locate the isotherm $600-700{ }^{\circ} \mathrm{C}$ within the temperature gradient (rift geotherm; Précigout et al., 2017). Following the transition to the east between the spinel-bearing peridotites and plagioclase-bearing peridotite, one ends up to the contact with the Nieves Unit where the temperature has been estimated around $600{ }^{\circ} \mathrm{C}$ (Mazzoli et al., 2013; Bessière, 2019). As supported by the metamorphic ages of $20 \mathrm{Ma}$ found in marbles of the Nieves Unit, this last extensional event may have occurred during back-arc extension of the Alboran Domain over OligoceneMiocene times (Précigout et al., 2013; Frasca et al., 2017; Gueydan et al., 2019). Nevertheless, one weak point of this interpretation is however the lack of evidence for crustal thickening before this extensional event. Extension in the back-arc domain behind the westward migrating accretionary wedge supposes that the back-arc extension is set upon the internal parts of the accretionary wedge (Jolivet et al., 1994, 2003; Brun and Faccenna, 2008). The section observed between the exhumed peridotite and the Nieves carbonate does not show any evidence for Alpine nappe stacking, which suggests that extension was set on a lithosphere that was subducted but not thickened, and the back-arc context thus cannot be ascertained. This leaves open the possibility that the deformation observed in the plagioclase-tectonite is related to the Mesozoic exhumation episode also.

Despite remaining uncertainties on the timing of mantle exhumation in the Western Alpujárride-Sebtide Complex, five main tectonic/geodynamic episodes can be proposed for the evolution of the Betics-Rif Cordillera. This timing is illustrated by Figure $14 \mathrm{C}$ showing the $P-T$ paths of the AlpujárrideSebtide and Nevado-Filábride Complexes decorated with color representing ages:

- the first episode dates back to the Permian around ca. 290 $280 \mathrm{Ma}$. It is characterized by partial melting in basement units in contact with the peridotite massifs, but also in the basement of the central Alpujárride Complex. It is widely interpreted as the result of the collapse and extension of the Variscan belt with a first episode of exhumation of the mantle peridotite;

- the second episode is derived from Jurassic (180 Ma) and Early Cretaceous (130 Ma) ages in the peridotite and in the gneiss of Jubrique unit. The dated pyroxenite dykes in the peridotite suggest that melt extraction and a second episode of rifting and mantle exhumation occurred in the Mesozoic with some decompression melting of the exhumed mantle. This rifting episode is well established all around the Iberian plate (Asti et al., 2019; Pedrera et al., 2020). We thus assume here that both the peridotite and Jubrique unit were from then on the same vertical and moved as a coherent block afterward, the Nieves-Los Reales detachment being frozen;

- the third episode relates to the Alpine orogeny with the subduction of the Alpujárride and Nevado-Filábride Complexes in the Eocene, following our reinterpretation of the radiometric ages in both complexes. It is recorded with cold HP-LT conditions in the central and eastern Alpujárride Complex and warmer conditions in the western Alpujárride Complex. It reaches the conditions of the eclogite-facies in the Bédar-Macael unit of the NevadoFilábride. It ends at about $38 \mathrm{Ma}$ in the central and eastern Alpujárride and later, until at least ca. $34 \mathrm{Ma}$ in the western Alpujárride Complex. The exact timing of subduction of the Nevado-Filábride Complex and the Alpujárride Complex cannot be further precised with available data. The higher pressure in the Nevado-Filábride Complex shows that this complex has subducted deeper than the Alpujárride Complex. It has then been exhumed up to lowpressure conditions below the Filabres Detachment, but no data constrain the deformation history between the peak of pressure and the late exhumation. One may assume that the top-to-the north shearing recorded in the Alpujárride Complex also played a role in the exhumation of the Nevado-Filábride Complex, but this is not constrained. This is however the option we have chosen for drawing 
Figure 15 showing the progressive subduction of the Alboran domain and its progressive exhumation along a NWSE cross-section before $20 \mathrm{Ma}$. Assuming full exhumation of the peridotites during Jurassic rifting, one can suppose that the peridotite and the Nieves Unit were subducted to shallow depths at this period, deep enough to reset the ${ }^{40} \mathrm{Ar} /{ }^{39} \mathrm{Ar}$ system in micas but shallow enough to keep the upper part of the Nieves Mesozoic sediments at low temperature and pressure and thus poorly metamorphosed;

- the fourth episode is the transition from subduction and crustal thickening to back-arc extension around 28-30 Ma. Well ascertained in the whole Mediterranean realm, it is attested in metamorphic rocks of the Alboran Domain by the reworking of the Alpujárride nappe stack during the Miocene by low-angle detachments and by the hightemperature evolution of some of the basement units. The 27 Ma age of Platt et al. (1998) or the initiation of extension due to convective removal of the lithospheric root is in line with this timing. A late part of mantle exhumation could have been achieved at this stage in the back-arc region if it has not been completed during the Mesozoic. This question remains to be studied;

- the fifth episode corresponds to the clustering of ages around $20 \mathrm{Ma}$. These ages are ubiquitous in the Alpujárride Complex and correspond to a sudden episode of exhumation and cooling associated with the overthrusting of the whole Alboran Domain onto the Iberian margin. This fast regional exhumation is associated with the overthrusting of the peridotite and associated crustal units on top of the Iberian margin and with the intrusion of granitic dykes in the peridotite and the host rocks suggesting that some partial melting was affecting the crust underneath. Final cooling and exhumation is now quite well documented in the middle Miocene by $\mathrm{U} / \mathrm{Pb}$ ages on allanite (Santamaria-Lopez et al., 2019) and LT thermochronology (fission-track) (e.g. Johnson et al., 1997). Finally, the main observations pleading for a high-temperature event at around $20 \mathrm{Ma}$, until $18 \mathrm{Ma}$, is the intrusion of leucocratic dykes in the peridotite and country rocks suggesting partial melting of the crust underneath. We thus have at this crucial period the concomitance of partial melting in the base of the crust of the Alpujárride Complex and the overthrusting (obduction in Gueydan et al., 2019) of the subcontinental mantle on top of the Iberian and North African margins.

\subsection{Conceptual model for the Early Miocene event}

Keeping in mind this debate on the timing and context of exhumation of the peridotite massifs, we now discuss a simple conceptual model for the $20 \mathrm{Ma}$ event. In the early Miocene, the whole Internal domain is exhumed fast and overthrusts the Iberian and North African margins. The recognition of partially molten crust underneath the peridotite at or slightly after $20 \mathrm{Ma}$ shows that the peridotite had already been thrusted upon some continental crust in the meantime (between 28 and $20 \mathrm{Ma}$ ). At around $20 \mathrm{Ma}$, a slab tear episode occurred and the slab delaminated and started its westward retreat (Maury et al., 2000; Jolivet et al., 2006). One can then suppose that this delamination led to a sudden heating event in the lower crust underneath the peridotite, which drastically lowered the resistance of the crust and allowed the decoupling between the peridotite and the remaining subducting lithosphere. The peridotite and its host rocks were then exhumed fast within the subduction channel and were carried by thrusts on top of the Iberian margin. This sudden exhumation froze all the isotopic systems in the whole Internal zones. Note nevertheless that this model assumes that the deformation stages recorded in the Ronda peridotite are not related to the Miocene back-arc extension, but only to previous extensional events (Jurassic rifting and/or late Paleozoic post-orogenic collapse), which faces several other problems as mentioned above.

\subsection{The main tectonometamorphic steps, reconstructions, paleogeographic maps and cross- sections}

Based on the above review we now propose a progressive evolution of the Alboran region with cross-sections (Figs. 15 and 16) and maps (Fig. 17). In this protracted evolution, the debate about the age and context of exhumation of the Ronda and Beni Bousera peridotite massifs has not reached a consensus yet and more studies are needed to unravel this problem. Figure 16 thus shows the two solutions on the $28 \mathrm{Ma}$ stage, either an early exhumation during the Tethyan rifting episode or a later exhumation during the Oligo-Miocene backextension in the Alboran Sea. If one considers that the exhumation of the peridotite cannot be achieved within the back-arc domain, as discussed above, this exhumation must have taken place earlier within the Tethyan rift during the Mesozoic (case A on Fig. 16). If instead it has taken place within the back-arc domain (case B) it occurred during the Oligocene.

The maps are constructed from the detailed kinematic reconstructions of Romagny et al. (2020). The cross-sections show the evolution at lithospheric scale of an E-W transect, thus focusing on the post-20 Ma evolution, after the main kinematic change in the Internal Zones and the fast exhumation event. The first step at $\sim 145 \mathrm{Ma}$ in the maps is inspired from the work of Leprêtre et al. (2018) and the pre-20 Ma is partly inspired by Michard et al. (2002) and Chalouan and Michard (2004). The successive steps in the tectonometamorphic evolution of the Alpujárride and Nevado-Filábride Complexes can be summarized as follows:

- in the late Paleozoic, in the aftermath of the Variscan orogeny, a large part of Western Europe is subjected to crustal collapse and formation of a wide rift system (Soto et al., 2017). Rifting in the Alboran Domain was associated with high-temperature metamorphism and partial melting in the lower crust, as discussed above. This event is recorded in the basement of the Alpujárride units and in the lower crust at the contact with the Beni Bousera and Ronda peridotites;

- in the Mesozoic, extension leads to rifting of the NeoTethys Ocean (Figs. 15 and 17). The various Triassic sequences (Alpine versus Germanic) are deposited in an extensional context. Locally, hyper-extension leads to the exhumation of sub-continental mantle. Depending on the chosen hypothesis, the Ronda peridotite may have been fully or partially exhumed by the Nieves-Los Reales detachment at 

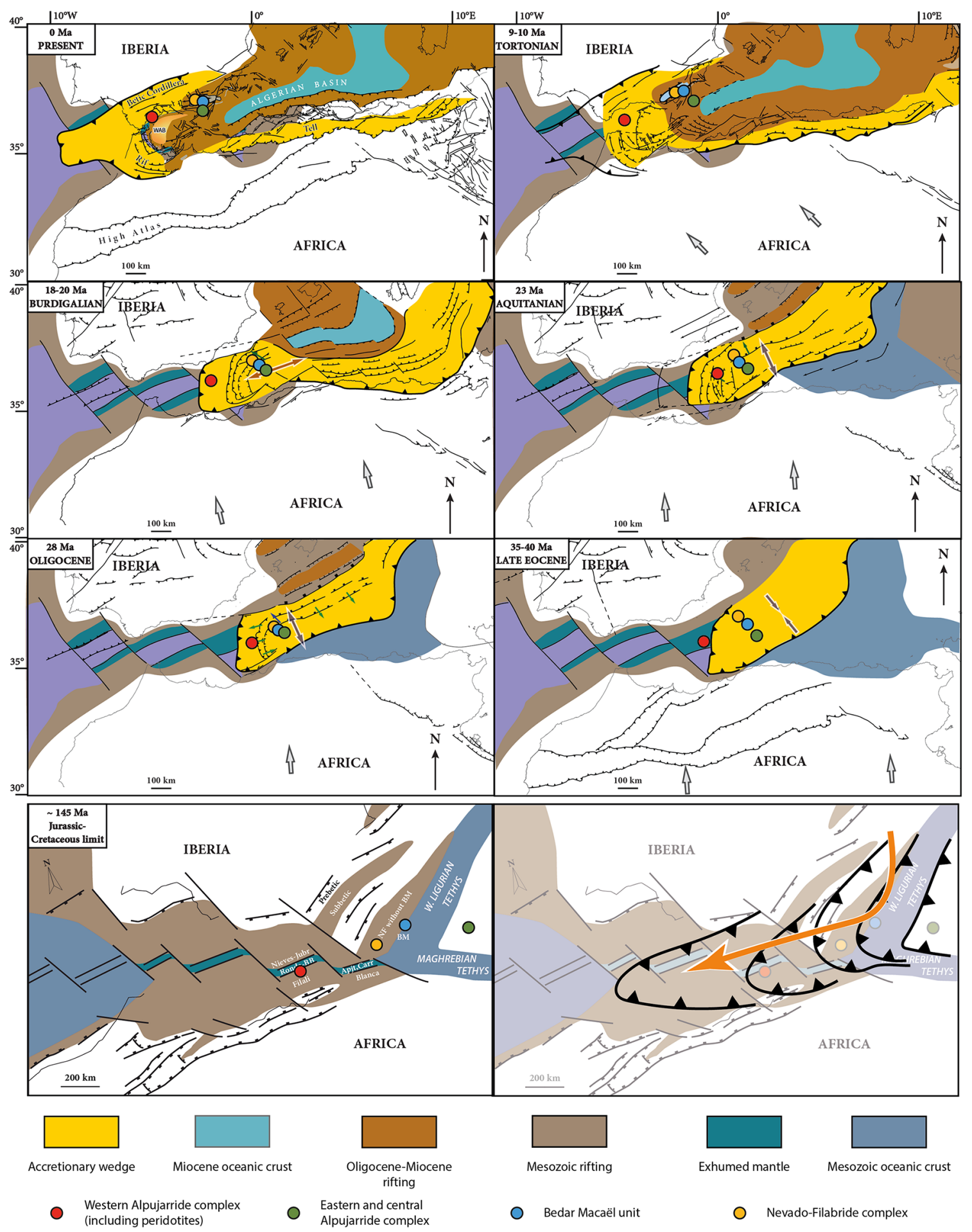

Fig. 17. Reconstructions in map view of the evolution of the Western Mediterranean, modified after Leprêtre et al. (2018) and Romagny et al. (2020). The yellow domain represents the Alboran Domain progressively deforming and migrating through time. At the surface it is mainly the Malaguide Complex and at depth the Alpujárride-Sebtide Complex. It progressively incorporates units by tectonic accretion at the expense of the rifted domain or partly oceanized Betic Ocean. The lower right panel shows the basic principle of this complex 3-D evolution where a noncylindrical rift partly evolved into oceanic domains is progressively incorporated into the accretionary wedge during slab retreat leading to the variations in P-T evolution from east to west in the Betic Cordillera. Before 20 Ma shortening is mostly N-S or NW-SE and the kinematics of exhumation is also along the same direction. After $20 \mathrm{Ma}$ the main kinematics is E-W with a migration of the Alboran domain and retreat of the slab toward the west. Nieves-Jubr: Nieves Unit and Jubrique Unit, Ronda-BB: Ronda and Beni Bousera peridotites, Apjt,Carr: Sierra Alpujata and Sierra de Carratraca peridotites, NF without BM: Nevado-Filábride without Bédar-Macael unit, BM: Bédar-Macael Unit. 
this period. The paleogeography of the Triassic formations in the Alpujárride Complex, the Bédar-Macael domain and the Calar Alto/Ragua units in the Nevado-Filábride Complex shows a series of NE-SW striking zones of rifted continental blocks within the future margins of the Betic Ocean and Maghrebian Tethys oceanic domain. The Bédar-Macael unit and the Ronda/Beni Bousera peridotite represent domains of hyper-extension or ocean-continent transition. In the Jurassic and until the Early Cretaceous, extension continues all around the Iberian plate and also in the Peri-Alpine domain. The Alpine Tethys rifting event takes place in the Early Jurassic, but rift basins with evidence of hyper-extension are recognized until the Early Cretaceous in the Pyrenees. The exhumation of the Los Reales peridotite may have taken place at this period as well. The domain where these hyper-extended basins form is wide, from the Pyrenees in the north to the Rif in the south. This evolution leads to the formation of a wide zone of juxtaposed rifts and hyper-extended domains within the narrow zone between Africa and Iberia. Two oceanic or partly oceanic domains are present, the Maghrebian Tethys to the south of the AlKaPeca block, and the Betic Ocean to the north. The future Calar-Alto and Ragua Nappes of the Nevado-Filábride Complex belongs to the passive margin basement of Iberia. The Bédar-Macael nappe belongs either to the distal passive margin and continent-ocean transition or to the Betic Ocean. The MalaguideGhomaride Complex makes the center of the AlKaPeca block at this period and the Alpujárride and Sebtide Complex are its passive margins. Note that there is no major difference in the Alpujárride and Sebtide lithostratigraphy, so that the exact attribution of individual units to either margins of AlKaPeca is highly speculative. Moreover, the post-20 Ma westward drift of the Alboran domain above the retreating slab and the associated clockwise and counterclockwise rotations on the either make this exercise even more speculative;

- in the Late Cretaceous, convergence takes over between Africa and Eurasia and the first compressional deformations are observed in the Pyrenees and probably also along the southern margin of Iberia;

- in the Eocene, the passive margin of Iberia and the margin of the Alboran block, together with the hyper-extended domains are subducted to the depth of the blueschists and eclogite facies (down to $\sim 60 \mathrm{~km}$ ) underneath the Malaguide-Ghomarides Complex that are not affected by the $\mathrm{H} P$-L $T$ nor later HT-LP metamorphism (Fig. 15). Starting from the Mesozoic rifted geometry, convergence is accommodated by the northward subduction of the Maghrebian Tethys in the south and the southward subduction of the Betic Ocean in the north. This crosssection is intended to fit the evolution of the Betics and Rif along a transect of the Central Alpujárride Complex. The geometry is compatible with the model of Chalouan and Michard (2004) and the reconstructions of Romagny et al. (2020). The northern subduction swallows the Betic Ocean and its margins, including the Alpujárride and the NevadoFilábride Complexes. The Sebtide Complex may originate from the southern margin of the $\mathrm{AlKaPeCa}$ block, but the 3-D complexity of the post-Eocene evolution is such that it could also be part of the northern margin. The subduction of the Betic Ocean and its margins leads to the formation of an accretionary wedge in $\mathrm{H} P$ - $\mathrm{L} T$ conditions and the top-tothe north overthrusting of the Alpujarride Complex on top of the Bédar-Macael unit and the latter unit on top of the Calar Alto unit. Some of these units are exhumed soon after the peak of metamorphism below the Malaguide-Alpujárride Contact (MAC) detachment with N-S extension and top-to-the north kinematics, ensuring a relative preservation of the $\mathrm{HP}$-L $T$ parageneses in the Salobreña, Escalate and Beni-Mzala Units. This subduction progressively incorporates both Alpujárride-Sebtide and Nevado-Filábride Complexes subducting below the Malaguide-Ghomaride Complex (Fig. 15). While the main subduction is toward the north (Africa under Iberia and Eurasia), the Betic-Rif orogen corresponds at this longitude to the subduction of the Betic Ocean and the margins of Iberia and $\mathrm{AlKaPeCa}$ underneath the Malaguide. This backthrust subduction is situated above the northward subduction of Africa of the Maghrebian Tethys, a true oceanic domain. In this context, the $P / T$ gradient is cold, typical of subduction environments. From east to west, the nature of the subducting lithosphere changes from a true oceanic lithosphere in the Maghrebian Tethys and its passive margin toward a more continental domain with ribbons of exhumed mantle (Figs. 16 and 17);

- the future western Alpujárride units are probably the last to enter the subduction zone as the few information on the age of the peak pressure suggest that it was reached later that in the Eastern Alpujárride Complex. They were thus not exhumed before the inception of slab retreat some $30 \mathrm{Ma}$ ago (Fig. 16) but reheated within the back-arc domain before their exhumation. Also, the subduction here does not involve any true oceanic lithosphere, at variance with the earlier period, but only thinned continental crust and mantle pieces. This may also contribute to warmer $P / T$ gradients during subduction. This is the period of intense extension in the whole Alpujárride domain and the NievesLos Reales Detachment could have also partly been formed or reactivated at this period, finally exhuming the subcontinental mantle of the Ronda peridotite. The transition to slab retreat and back-arc extension leads to an increase of the heat flow underneath the orogen and the reworking of those $\mathrm{H} P$-L $T$ units that had not yet been exhumed in $\mathrm{H} T$ $\mathrm{L} P$ metamorphic facies during the Oligocene;

- at about $20 \mathrm{Ma}$, after the docking of the AlkaPeCa units with the northern margin of Africa, the African slab is broken in two parts and the western half starts a fast westward retreat (Figs. 16 and 17), inducing the westward motion of the arc and back-arc with fast extension and subsidence, forming the West Alboran Basin and large west-dipping detachments such as the Filabres Shear Zone that exhumes the Nevado-Filábride Complex. The beginning of this episode is marked by a sudden change in the kinematics of extension from top-to-the north to top-to-the west and the overthrusting of the Alboran Domain ("obduction of the margin" in the sense of Gueydan et al., 2019) situated in the westernmost part of the backarc domain onto the margin of Iberia. Slab retreat is associated with a delamination of the subducting lithospheric mantle and the coeval ingression of asthenospheric material induces partial melting of the continental crust 
subducted below the peridotite. This change in the geodynamic setting leads to the decoupling of subducted material and the fast exhumation of the subduction wedge together with the whole orogen during its westward overthrusting on top of the margin of southern Iberia, freezing radiometric systems at around $20 \mathrm{Ma}$. The exhumation of the Nevado-Filábride Complex continues until the middle and early late Miocene accompanied with the formation of series of intramountain extensional basins;

- this situation lasts until about $8 \mathrm{Ma}$ when slab retreat stops and E-W extension is replaced by N-S shortening. The Miocene basins are partly inverted and the metamorphic domes are amplified, now forming the highest relief of the Betic Cordillera and NE-SW strike slip faults are formed and also accommodate this compression.

\section{Conclusions}

This review has permitted some progress toward the answer to three main questions:

- the timing of the HP-LT event in the Alpujárride and Nevado-Filábride MCC and thus the ages of the subduction episodes affecting the Alboran domain can be attributed to the Eocene. The case is clear for the central and eastern Alpujárride Complex with new ${ }^{40} \mathrm{Ar}-{ }^{39} \mathrm{Ar}$ ages. The case of the Nevado-Filábride Complex can still be debated, but a series of evidence also lead us to assign it to the Eocene, coeval, in a broad sense, with the subduction of the central and eastern Alpujárride Complex;

- the mechanisms of emplacement of the sub-continental peridotite massifs of both the Rif and the Betics involves hyper-extension either during the late Paleozoic, the Mesozoic or the Miocene. The contact between the Ronda peridotite and the Jubrique and Nieves Units is a large extensional shear zone, the peridotite massif itself being a mantle core complex similar to those observed along slow mid-oceanic ridges. The question of the timing of extension remains open;

- the observed clustering of radiometric ages around $20 \mathrm{Ma}$ results from a sudden exhumation episode of the entire Alboran Domain triggered by slab retreat and delamination inducing the ingression of asthenospheric mantle and the partial melting of the deepest part of the accretionary wedge in the west and its decoupling from the subducting lithosphere.

We then proposed a scenario of the evolution of the BeticRif Internal Zones in maps and cross-sections based on a discussion and reevaluation of the geological data base. The different evolutions of the western Alpujárride units compared to the eastern and central Alpujárride is the consequence of (1) the non-cylindrical geometry of the African and Iberian passive margins in the Mesozoic and (2) the complex 3-D behavior of the slab during retreat and delamination.

The non-cylindricity of the Betic-Rif orogen is then the consequence of two main factors:

- the first factor of the 3D complexity is the tectonic inheritance from the 3D geometry of the pre-orogenic template. The difference in the $P-T$ evolution of the eastern and western Alpujárride units is a consequence of their paleogeographic situation. The eastern and central Alpujárride were subducted and exhumed early above a normal oceanic subduction associated with a cold $P / T$ gradient, while the western Alpujárride units correspond to the subduction of a thinned continental crust without any large oceanic domain. The progressive digestion of these different domains from east to west led to this difference in $P-T$ evolution with warmer conditions in the west. This contrast is exacerbated by the slab tearing episode that led to the ingression of asthenospheric material below the orogen and facilitated exhumation. Those units that were exhumed early have escaped the Miocene heating while those stored at depth recorded a high-temperature overprint. Such along-strike differentiation is probably true of all orogens, but it is more sensitive in small mountain belts where the original geometry is still partly preserved and the overall shortening not large;

- the second factor is the complex slab dynamics in a confined space typical of the Mediterranean orogens. The main reason for the sudden change in the exhumation kinematics some $20 \mathrm{Ma}$ ago is the slab tearing event that occurred when the retreating $\mathrm{AlKaPeCa}$ block docked on the North African margin. This complex dynamics is also a consequence of the complex 3-D geometry of the African and Eurasian margins of the Neo-Tethys.

Despite the detailed knowledge of both the Betic Cordillera and the Rif accumulated so far, some basic questions still remain open. One of the most important questions is probably the emplacement mechanism of the Ronda and Beni Bousera peridotite and its timing. The exact timing and kinematics of the superposition of the Alpujárride-Sebtide on top of the Nevado-Filábride is another important question. One of the main tools needed to go forward is a better and more systematic radiochronological study on unambiguous material that are less likely to have recorded a succession of pre-Alpine tectono-metamorphic events.

Acknowledgments. This paper is a contribution of the Orogen project funded by Total, BRGM and CNRS-INSU and it benefited from numerous discussions with the Orogen community. The ${ }^{40} \mathrm{Ar} /{ }^{39} \mathrm{Ar}$ facility at ISTO was funded and is supported by the ERC Advanced grant RHEOLITH, the LABEX project VOLTAIRE (ANR-10-LABX-100-01), the Région Centre project ARGON, and the project EQUIPEX PLANEX (ANR-11-EQPX-0036). We would to thank the guest-editor David Pedreira and the two reviewers, Juan Soto and André Michard for a really extensive analysis of our manuscript, which is obviously in better shape now. Special thanks are due to Federico Rossetti who commented on an early version of the manuscript.

\section{References}

Acosta-Vigil A, Rubatto D, Bartoli O, Cesare B, Meli S, Pedrera A, et al. 2014. Age of anatexis in the crustal footwall of the Ronda peridotites, S Spain. Lithos 210-211: 147-167.

Agard P, Yamato P, Jolivet L, Burov E. 2009. Exhumation of oceanic blueschists and eclogites in subduction zones: timing and mechanisms. Earth Science Reviews 92: 53-79. 
Agard P, Augier R, Monié P. 2011. Shear band formation and strain localization on a regional scale: Evidence from anisotropic rocks below a major detachment (Betic Cordilleras, Spain). Journal of Structural Geology 33: 114-131.

Agard P, Yamato P, Soret M, Prigent C, Guillot S, Plunder A, et al. 2016. Plate interface rheological switches during subduction infancy: Control on slab penetration and metamorphic sole formation. Earth and Planetary Science Letters 451: 208-220. https://doi.org/210.1016/j.eps1.2016.1006.1054.

Aldaya, F., García-Dueñas, V. 1976. Les séquences lithologiques de nappes Alpujárrides au sud et au sud-ouest de la Sierra Nevada (Cordillères bétiques, Andalousie). Bull. Soc. Géol. France 18: 635639.

Andrieux J, Fontboté JM, Mattauer M. 1971. Sur un modèle explicatif de l'arc de Gibraltar. Earth Planet. Sci. Lett. 12: 191-193.

Angrand P, Mouthereau F, Masini E, Asti R. 2020. A reconstruction of Iberia accounting for W-Tethys/N-Atlantic kinematics since the late Permian-Triassic. Solid Earth, European Geosciences Union. https://doi.org/10.5194/se-2020-5124.

Argles TW, Platt JP, Waters DJ. 1999. Attenuation and excision of a crustal section during extensional exhumation: the Carratraca massif, Betic Cordillera, southern Spain. J. Geol. Soc. London 156: 149-162.

Asti R, Lagabrielle Y, Fourcade S, Corre B, Monié P. 2019. How do continents deform during mantle exhumation? Insights from the northern Iberia inverted paleopassive margin, western Pyrenees (France). Tectonics 38: 1666-1693. https://doi.org/1610.1029/ 2018TC005428.

Augier R, Agard P, Jolivet L, Monié P, Robin C, Booth-Rea G. 2005a. Exhumation, doming and slab retreat in the Betic Cordillera (SE Spain): in situ 40Ar/39Ar ages and $\mathrm{P}-\mathrm{T}-\mathrm{d}-\mathrm{t}$ paths for the NevadoFilábride complex. J. Metam. Geol. 23: 357-381. https://doi.org/ 310.1111/j.1525-1314.2005.00581.x.

Augier R, Booth-Rea G, Agard P, Martinez-Martinez JM, Jolivet L, Azañón JM. 2005b. Exhumation constraints for the lower NevadoFilábride Complex (Betic Cordillera, SE Spain): a Raman thermometry and Tweequ multiequilibrium thermobarometry approach. Bull. Soc. Géol. Fr. 176: 403-416. https://doi.org/410.2113/ 2176.2115.2403.

Augier R, Jolivet L, Do Couto D, Negro F. 2013. From ductile to brittle, late- to post-orogenic evolution of the Betic Cordillera: Structural insights from the northeastern Internal zones. Bull Soc Géol Fr 184: 405-425.

Azañón JM, Crespo-Blanc A. 2000. Exhumation during a continental collision inferred from the tectonometamorphic evolution of the Alpujárride Complex in the central Betics (Alboran Domain, SE Spain). Tectonics 19: 549-565.

Azañón JM, Crespo-Blanc A, García-Dueñas V. 1997. Continental collision, crustal thinning and nappe-forming during the preMiocene evolution of the Alpujárride Complex (Alboran Domain, Betics). J Struct Geol 19: 1055-1071.

Azañón JM, Garcia Dueñas V, Martinez-Martinez JM, Crespo-Blanc A. 1994. Alpujárride tectonic sheets in the Central Betics and similar eastern allochtonous units (SE Spain). C R Acad. Sci 318: 667-674.

Azañón JM, García-Dueñas V, Goffé B. 1992. High pressure mineral assemblages in the Trevenque Unit (Central Alpujárrides, Andalucía). Geogaceta 11: 81-84.

Azañón JM, García-Dueñas V, Goffé B. 1998. Exhumation of highpressure metapelites and coeval crustal extension in the Alpujárride complex (Betic Cordillera). Tectonophysics 285: 231-252.

Azañón JM, Goffé B. 1997. High-pressure, low-temperature metamorphic evolution of the Central Alpujárrides, Betic cordillera (S.E. Spain). Eur J Miner 9: 1035-1051.
Azdimousa A, Bourgois J, Poupeau G, Vázquez M, Asebriy L, Labrin E. 2013. Fission track thermochronology of the Beni Bousera peridotite massif (Internal Rif, Morocco) and the exhumation of ultramafic rocks in the Gibraltar Arc. Arab J Geosci. https://doi. org/10.1007/s12517-12013-10924-12513.

Bakker HE, de Jong K, Helmers H, Biermann C. 1989. The geodynamic evolution of the Internal Zone of the Betic Cordilleras (south-east Spain): a model based on structural analysis and geothermobarometry. J Metamorph Geol 7: 359-381.

Balanyá JC, García-Dueñas V. 1987. Les directions structurales dans le Domaine d'Alborán de part et d'autre du Détroit de Gibraltar. C R Acad Sci 304: 929-932.

Balanyá JC, García-Dueñas V, Azañón JM, Sanchez-Gómez M. 1997. Alternating contractional and extensional events in the Alpujárride nappes of the Alboran Domain. Tectonics 16: 226 238.

Barich A. 2016. Unravelling the anatectic history of the lower conteninental crust through the petrology of melt inclusions and Lu-Hf garnet geochronology: a case study from the western Alpujárrides (Betic Cordillera, S. Spain). Universidad de Granada, pp. 200.

Barich A, Acosta-Vigil A, Garrido CJ, Cesare B, Tajčmanová L, Bartoli O. 2014. Microstructures and petrology of melt inclusions in the anatectic sequence of Jubrique (Betic Cordillera, S Spain): Implications for crustal anatexis. Lithos 206-207: 303-320. https://doi.org/310.1016/j.lithos.2014.1008.1003.

Bartoli O, Tajcmanova L, Cesare B, Acosta-Vigil A. 2013. Phase equilibria constraints on melting of stromatic migmatites from Ronda (S. Spain): insights on the formation of peritectic garnet. J Metamorph Geol 31: 775-789. https://doi.org/710.1111/ jmg. 12044.

Beaudoin A, Scaillet S, Mora N, Jolivet L, Augier R. 2020. In situ and step-heating 40Ar/39Ar dating of white mica in low-temperature shear zones (Tenda Massif, alpine Corsica, France). Tectonics: e2020TC006246. https://doi.org/006210.001029/002020TC006246.

Behr WM, Platt JP. 2012. Kinematic and thermal evolution during two-stage exhumation of a Mediterranean subduction complex. Tectonics 31: TC4025.

Bessière E. 2019. Evolution géodynamique des zones internes des Cordillères Bétique (Andalousie, Espagne): apports d'une étude pluridisciplinaire du complexe Alpujárride, OSUC. Orléans: Université d'Orléans, pp. 316.

Beyssac O, Goffé B, Chopin C, Rouzaud JN. 2002. Raman spectra of carbonaceous material from metasediments: a new geothermometer. J Metam Geol 20: 859-871. https://doi.org/810.1046/ j.1525-1314.2002.00408.x.

Bezada MJ, Humphreys ED, Toomey DR, Harnafi M, Davila JM, Gallart J. 2013. Evidence for slab rollback in westernmost Mediterranean from improved upper mantle imaging. Earth Planet Sci Lett 368: 51-60. https://doi.org/10.1016/j.epsl.2013.1002.1024.

Blichert-Toft J, Albarède F, Kornprobst J. 1999. Lu-Hf isotope systematics of garnet pyroxenites from Beni Bousera, Morocco: Implications for basalt origin. Science 283: 1303-1306.

Blumenthal M. 1927. Versuch einer tektonishen Gliederung der Betischen Kordilleren von Central und Sudwest Andalusien. Eclogae Geol Helv 20: 487-592.

Boillot G, Girardeau J, Kornprobst J. 1988. Rifting of the Galicia margin: crustal thinning and emplacement of mantle rocks on the seafloor. In: Boillot G, Winterer EL, Eds. Proc. Ocean Dril. Prog., Sci. Results, pp. 741-756.

Booth-Rea G, Azañón JM, Goffé B, Vidal O, Martínez-Martínez JM. 2002. High-pressure low-temperature metamorphism in the Alpujárride Units outcropping in the southeastern Betics (Spain). C R Geosci 334: 857-865. 
Booth-Rea G, Azañón JM, Azor A, García-Dueñas V. 2004. Influence of strike-slip fault segmentation on drainage evolution and topography. A case study: the Palomares fault zone (southeastern Betics, Spain). Journal of Structural Geology 26: 1615-1632.

Booth-Rea G, Azañón JM, Martínez-Martínez JM, Vidal O, GarcíaDueñas V. 2005. Contrasting structural and P-T evolution of tectonic units in the southeastern Betics: Key for understanding the exhumation of the Alboran Domain HP/LT crustal rocks (western Mediterranean). Tectonics 24.

Booth-Rea G, Martínez-Martínez JM, Giaconia F. 2015. Continental subduction, intracrustal shortening, and coeval upper-crustal extension: P-T evolution of subducted south Iberian paleomargin metapelites (Betics, SE Spain). Tectonophysics 663: 122-139.

Booth-Rea G, Ranero CR, Martinez-Martinez JM, Grevemeyer I. 2007. Crustal types and Tertiary tectonic evolution of the Alborán sea, western Mediterranean. Geochem Geophys Geosyst 8: Q10005. https://doi.org/10010.11029/12007GC001639.

Borque MJ, Sánchez-Alzola A, Martin-Rojas I, Alfaro P, Molina S, Rosa-Cintas S, et al. 2019. How much Nubia-Eurasia convergence is accommodated by the NE end of the Eastern Betic Shear Zone (SE Spain)? Constraints from GPS velocities. Tectonics 38: 18241839. https://doi.org/1810.1029/2018TC004970.

Bouillin JP, Durand-Delga M, Olivier P. 1986. Betic, Rifian and Tyrrhenian arcs: distinctive features, genesis and development stage. In: Wezel FC, Ed. The origin of Arcs. New York: Elsevier, pp. 281-304.

Bourgois J, Chauve P, Magne J, Monnot J, Peyre Y, Rigo E, et al. 1972. La formation de Las Millanas. Série burdigallienne transgressive, sur les zones internes des cordillères bétiques occidentales (région d'Alozoina-Tolox, province de Malaga, Espagne). C R Acad Sci 275: 169-172.

Bourgois J, Mauffret A, Ammar A, Demnati A. 1992. Multichannel seismic data imaging of inversion tectonics of the Alboran Ridge (western Mediterranean Sea). Geo-Marine Letters: 117-122.

Bousquet R, Goffé B, Henry P, Le Pichon X, Chopin C. 1997. Kinematic, thermal and petrological model of the Central Alps: Lepontine metamorphism in the Upper Crust and eclogitisation of the lower crust. Tectonophysics 273: 105-128.

Bousquet R, Oberhänsli R, Goffé B, Wiederkehr M, Koller F, Schmid $\mathrm{SM}$, et al. 2008. Metamorphism of metasediments at the scale of an orogen: a key to the Tertiary geodynamic evolution of the Alps. In: Siegiesmund S, Fügenschuh B, Froitzheim N, Eds. Tectonic Aspects of the Alpine-Dinaride-Carpathian System. London: The Geological Society of London, pp. 393-411. https://doi.org/ 310.1144/SP1298.11180305-8719/1108/\$1115.1100.

Bouybaouene ML, Goffé B, Michard A. 1995. High-pressure, lowtemperature metamorphism in the Sebtides nappes, northern Rif, Morocco. Geogaceta 17: 117-119.

Brandão JASL, Feijó FJ. 1994. Bacia da foz do Amazonas. Bol Geociencias PETROBRAS 8: 91-99.

Briend M, Montenat C, Ott d'Estevou P. 1990. Le bassin de HuercalOvera. In: Montenat C, Ed. Les bassins Neogenes du Domaine Betique Oriental (Espagne) 12-13, pp. 239-259.

Brun JP, Faccenna C. 2008. Exhumation of high-pressure rocks driven by slab rollback. Earth and Planetary Sciences Letters 272: 1-7. https://doi.org/10.1016/j.epsl.2008.1002.1038.

Brun JP, Sokoutis D, Tirel C, Gueydan F, Van den Driessche J. 2018. Crustal versus mantle core complexes. Tectonophysics 746: 22-45.

Brune S, Heine C, Pérez-Gussinyé M, Sobolev SV. 2014. Rift migration explains continental margin asymmetry and crustal hyper-extension. Nature Communications 5: 4014. https://doi.org/ $10.1038 /$ ncomms 5014 .
Burg JP, Davy P, Nievergelt P, Oberli F, Seward D, Zhizhong D, Meier M. 1997. Exhumation during crustal folding in the Namche-Barwa syntaxis. Terra Nova 9: 53-56.

Casciello E, Fernandez M, Vergés J, Cesarano M, Torne M. 2015. The Alboran domain in the western Mediterranean evolution, the birth of a concept. Bull Soc Géol Fr 186: 371-384.

Chalouan A, Michard A. 1990. The Ghomarides Nappes, Rif Coastal Range, Morocco: A Variscan Chip in the Alpine Belt. Tectonics 9: 1565-1583.

Chalouan A, Michard A. 2004. The Alpine Rif Belt (Morocco): A Case of Mountain Building in a Subduction-SubductionTransform Fault Triple Junction. Pure Appl Geophys 161: 489519. https://doi.org/410.1007/s00024-00003-02460-00027.

Chalouan A, Michard A, El Kadiri K, Negro F, Frizon de Lamotte D, Soto JI, et al. 2008. The Rif Belt. In: Michard A, et al., Ed. Continental Evolution: The Geology of Morocco, Lecture Notes 203 in Earth Sciences. Berlin, Heidelberg: Springer-Verlag Berlin Heidelberg.

Chalouan A, Michard A, Feinberg H, Montigny R, Saddiqi O. 2001. The Rif mountain building (Morocco): a new tectonic scenario. Bull Geol Soc Fr 242: 603-616.

Chalouan A, Saji R, Michard A, Bally AW. 1997. Neogene Tectonic Evolution of the Southwestern Alboran Basin as Inferred from Seismic Data Off Morocco. AAPG Bulletin 81: 1161-1184.

Chertova MV, Spakman W, Geenen T, van den Berg AP, van Hinsbergen DJJ. 2014. Underpinning tectonic reconstructions of the western Mediterranean region with dynamic slab evolution from 3-D numerical modeling. J Geophys Res Solid Earth 119: 5876-5902. https://doi.org/5810.1002/2014JB011150.

Chevrot S, Sylvander M, Diaz J, Martin R, Mouthereau F, Manatschal G, et al. 2018. The non-cylindrical crustal architecture of the Pyrenees. Scientific Reports 8: 9591. https://doi.org/9510.1038/s41598-4101827889-x.

Cita MB. 1973. Mediterranean evaporite - paleontological arguments for a deep basin dessication model. In: Drooger CW, Ed. Messinian Events in the Mediterranean. Amsterdam: Kon. Nederl. Aked. Wetensh., North-Holland Pub. Co., pp. 206-228.

Clauzon G, Suc JP, Do Couto D, Jouannic G, Melinte-Dobrinescu MC, Jolivet L, et al. 2015. New insights on the Sorbas Basin (SE Spain): The onshore reference of the Messinian Salinity Crisis. Marine and Petroleum Geology 66: 71-100. https://doi.org/ 110.1016/j.marpetgeo.2015.1002.1016.

Clauzon G, Suc JP, Gautier F, Berger A, Loutre MF. 1996. Alternate interpretation of the Messinian salinity crisis: controversy resolved? Geology 24: 363-366.

Clerc C, Boulvais P, Lagabrielle Y, de Saint Blanquat M. 2014. Ophicalcites from the northern Pyrenean belt: a field, petrographic and stable isotope study. Int J Earth Sci (Geol Rundsch) 103: 141163. https://doi.org/110.1007/s00531-00013-00927-z.

Clerc C, Lagabrielle Y, Neumaier M, Reynaud JY, de Saint Blanquat M. 2012. Exhumation of subcontinental mantle rocks: evidence from ultramafic-bearing clastic deposits nearby the Lherz peridotite body, French Pyrenees. Bull Soc Géol Fr 183: 443-459.

Clerc C, Lahfid A, Monié P, Lagabrielle Y, Chopin C, Poujol M, et al. 2015. High-temperature metamorphism during extreme thinning of the continental crust: a reappraisal of the North Pyrenean passive paleomargin. Solid Earth 6: 643-668. https://doi.org/610.5194/se5196-5643-2015.

Comas MC, García-Dueñas V, Jurado MJ. 1992. Neogene tectonic evolution of the Alboran Sea from MCS data. Geol Mar Lett 12: 157-164.

Comas MC, Platt JP, Soto JI, Watts AB. 1999. The origin and tectonic history of the Alboran basin: insights from Leg 161 results. In: 
Zahn R, Comas MC, Klaus A, Eds. Proc. ODP, Sci. Results. College Station: TX (Ocean Drilling Program), pp. 555-582.

Comas MC, Zanh R, Klaus A, et al. 1996. Leg 161 - Western Mediterranean. Init Repts of Ocean Drilling Program 161: 1-638.

Crespo-Blanc A. 1995. Interference pattern of extensional fault systems: a case study of the Miocene rifting of the Alboran basement (North of Sierra Nevada, Betic Chain). J Struct Geol 17: 1559-1569.

Crespo-Blanc A, Orozco M, García-Dueñas V. 1994. Extension versus compression during the Miocene tectonic evolution of the Betic chain. Late folding of normal fault system. Tectonics 13: 78-88.

Crespo-Blanc A, Comas M, Balanyá JC. 2016. Clues for a Tortonian reconstruction of the Gibraltar Arc: Structural pattern, deformation diachronism and block rotations. Tectonophysics 683: 308-324. https://doi.org/310.1016/j.tecto.2016.1005.1045.

Crespo-Blanc A, Frizon de Lamotte D. 2006. Structural evolution of the external zones derived from the flysch trough and the south Iberian and Maghrebian paleomargins around the Gibraltar arc: a comparative study. Bull Soc Géol Fr 177: 267-282.

d'Acremont E, Lafosse M, Rabaute A, Teurquety G, Do Couto D, Ercilla G, et al. 2020. Polyphase tectonic evolution of fore-arc basin related to STEP fault as revealed by seismic reflection data from the Alboran Sea (W- Mediterranean). Tectonics. https://doi. org/10.1029/2019TC005885.

Daudet M, Mouthereau F, Brichau S, Crespo-Blanc A, Gautheron C, Angrand P. 2020. Tectono-stratigraphic and thermal evolution of the western Betic flyschs: implications for the geodynamics of South Iberian margin and Alboran Domain. Tectonics. https://doi. org/10.1029/2020TC006093.

Davies GR, Nixon PH, Pearson DG, Obata M. 1993. Tectonic implications of graphitized diamonds from the Ronda peridotite massif, southern Spain. Geology 21: 471-474.

Davy P, Gillet P. 1986. The stacking of thrust slices in collision zones and its thermal consequences. Tectonics 5: 913-929.

De Jong G. 1993. The tectono-metamorphic evolution of the Veleta Complex and the development of the contact with the Mulhacen Complex (Betic Zone, SE Spain). Geol Mijnbouw 71: 227-237.

De Jong K, Wijbrans JR, Feraud G. 1992. Repeated Thermal Resetting of Phengites in the Mulhacen Complex (Betic Zone, Southeastern Spain) Shown By Ar-40/Ar-39 Step Heating and Single Grain Laser Probe Dating. Earth and Planetary Science Letters 110: 173-191.

de la Peña LG, Ranero CR, Gràcia E, Booth-Rea G. 2020. The evolution of the westernmost Mediterranean basins. Earth-Science Reviews. https://doi.org/10.1016/j.earscirev.2020.103445.

de Larouzière FD, Bolze $\mathrm{J}$, Bordet $\mathrm{P}$, Hernadez $\mathrm{J}$, Montenant $\mathrm{C}$, Ott d'Estevou P. 1988. The Betic segment of the lithospheric TransAlboran shear zone during the Late Miocene. Tectonophysics 152: 41-52.

de Lis Mancilla F, Booth-Rea G, Stich D, Pérez-Peña JV, Morales J, Azañón JM, et al. 2015. Slab rupture and delamination under the Betics and Rif constrained from receiver functions. Tectonophysics 663: 225-237. https://doi.org/210.1016/j.tecto.2015.1006.1028.

de Lis Mancilla F, Heit B, Morales J, Yuan X, Stich D, MolinaAguilera A, et al. 2018. A STEP fault in Central Betics, associated with lateral lithospheric tearing at the northern edge of the Gibraltar arc subduction system. Earth and Planetary Science Letters 486: 32-40. https://doi.org/10.1016/j.eps1.2018.1001.1008.

del Olmo Sanz A, Macía JG de P, Aldaya Valverde F, Campos Fernández J, Chacón Montero J, García Dueñas V, et al. 1987. Mapa Geológico de España, 1:50.000, hoja 1064 (Cortes de la Frontera). Instituto Geológico y Minero de España. de Orueta D. 1917. Estudio geológico y petrográfico de la Serranía de Ronda. Mem Inst Geol Espana.

De Smet MEM. 1984. Wrenching in the external zone of the Betics Cordilleras, Southern Spain. Tectonophysics 107: 57-79.

Diaz J, Gallart J, Carbonell R. 2016. Moho topography beneath the Iberian-Western Mediterranean region mapped from controlledsource and natural seismicity surveys. Tectonophysics 692: 74-85.

Didon J, García-Dueñas V. 1976. Réunion extraordinaire de la Société géologique de France: Les Cordillères bétiques centrales et orientales. Bull Soc Géol Fr 18: 583-599.

Dielforder A, Frasca G, Brune S, Ford M. 2019. Formation of the Iberian-European Convergent Plate Boundary Fault and Its Effect on Intraplate Deformation in Central Europe. Geochem Geophys Geosyst. https://doi.org/10.1029/2018GC007840.

Do Couto D, Gorini C, Jolivet L, Lebret N, Augier R, Gumiaux C, et al. 2016. Tectonic and stratigraphic evolution of the Western Alboran Sea Basin in the last 25 Myrs. Tectonophysics. https://doi. org/10.1016/j.tecto.2016.1003.1020.

Do Couto D, Gumiaux C, Augier R, Lebret N, Folcher N, Jouannic G, et al. 2014. Tectonic inversion of an asymmetric graben: Insights from a combined field and gravity survey in the Sorbas basin. Tectonics 33. https://doi.org/10.1002/2013TC003458.

Do Couto D, Gumiaux C, Jolivet L, Augier R, Lebret N, Folcher N, et al. 2015. 3D modelling of the Sorbas Basin (Spain): New constraints on the Messinian Erosional Surface morphology. Marine and Petroleum Geology 66: 101-116. https://doi.org/ 110.1016/j.marpetgeo.2014.1012.1011.

Doblas M, Oyarzun R. 1989. "Mantle core complexes" and Neogene extensional detachment tectonics in the western Betic Cordilleras, Spain: an alternative model for the emplacement of the Ronda peridotite. Earth Planet Sci Lett 93: 76-84.

Dodson MH. 1973. Closure temperature in cooling geochronological and petrological systems. Contr Mineral Petrol 40: 259-274.

Durand Delga M, Foucault A. 1967. La Dorsale bétique, nouvel élément paléogéographique et structural des Cordillères bétiques, au bord sud de la Sierra Arana (province de Grenade, Espagne). $C$ Romm Soc geol Fr 242.

Dürr SH. 1963. Geologie der Serrania de Ronda und ihrer südwestlichen Ausläufer (Andalusien). Univ. Bonn.

Egeler CG. 1963. On the tectonics of the eastern Betic Cordilleras. Geol Rundsch LIII: 260-263.

Egeler CG, Simon OJ. 1969. Sur la tectonique de la zone bétique (Cordillères Bétiques, Espagne). Etude basée sur sur la recherche dans le secteur compris entre Almeria et Velez Rubio. Verh Kon Ned Akad Wet Afd Natuurk 25: 1-90.

El Bakili A, Corsini M, Chalouan A, Münch P, Romagny A, Lardeaux JM, et al. 2020. Neogene polyphase deformation related to the Alboran Basin evolution: new insights for the Beni Bousera massif (Internal Rif, Morocco). BSGF - Earth Sciences Bulletin 191: 10. https://doi.org/10.1051/bsgf/2020008.

Esteban JJ, Cuevas J, Tubía JM, Seward D. 2004a. Determinación de la naturaleza de la falla de Cerro Tajo (Macizo peridotítico de Carratraca) mediante termocronología de trazas de fisión. Geogaceta 36: 43-46.

Esteban JJ, Sanchez-Rodriguez L, Seward D, Cuevas J, Tuba JM. 2004b. The late thermal history of the Ronda area, southern Spain. Tectonophysics 389: 81-92. https://doi.org/10.1016/j. tecto.2004.1007.1050.

Esteban JJ, Cuevas J, Tubía JM, Gil Ibarguchi JI, Seward D. 2005. Metamorfismo, exhumación y termocronología de la Unidad de Yunquera (Alpujárrides occidentales, Cordilleras Béticas). Rev Soc Geol Esp 18: 61-74. 
Esteban JJ, Cuevas J, Vegas N, Tubía JM. 2008. Deformation and kinematics in a melt-bearing shear zone from the Western Betic Cordilleras (Southern Spain). Journal of Structural Geology 30: 380-393. https://doi.org/310.1016/j.jsg.2007.1011.1010.

Esteban JJ, Cuevas J, Tubía JM, Sergeev S, Larionov A. 2011. A revised Aquitanian age for the emplacement of the Ronda peridotites (Betic Cordilleras, southern Spain). Geol Mag 148: 183-187.

Estrada F, Galindo-Zaldıvar J, Vazquez JT, Ercilla G, D’Acremont E, Alonso B, et al. 2017. Tectonic indentation in the central Alboran Sea (westernmost Mediterranean). Terra Nova 30: 24-33. https:// doi.org/10.1111/ter.12304.

Etheve N, Mohn G, Frizon de Lamotte D, Roca E, Tugend J, GómezRomeu J. 2018. Extreme Mesozoic crustal thinning in the eastern Iberia margin: The example of the Columbrets Basin (Valencia Trough). Tectonics 37. https://doi.org/10.1002/2017TC004613.

Faccenna C, Piromallo C, Crespo-Blanc A, Jolivet L, Rossetti F. 2004. Lateral slab deformation and the origin of the Western Mediterranean arcs. Tectonics 23. https://doi.org/10.1029/ 2002 TC001488.

Fallot P. 1937. Essai sur la géologie du Rif septentrional. Notes et Mémoire Service géologique du Maroc 40: $533 \mathrm{p}$.

Feinberg H, Maaté A, Bouhdadi S, Durand-Delga M, Maaté M, Olivier P. 1990. Signification des dépôts de l'Oligocène supérieurMiocène inférieur du Rif interne (Maroc), dans l'évolution géodynamique de l'arc de Gibraltar. C R Acad Sci Paris 310: 1487-1495.

Feinberg H, Saddiqi O, Michard A. 1996. New constraints on the bending of the Gibraltar Arc from palaeomagnetism of the Ronda peridotites (Betic Cordilleras, Spain). In: Morris A, Tarling DH, Eds. Palaeomagnetism and Tectonics of the Mediterranean region. Special Publication, 105. London: Geological Society, pp. 43-52.

Fernàndez M, Torne M, Vergés J, Casciello E, Macchiavelli C. 2019. Evidence of Segmentation in the Iberia-Africa Plate Boundary: A Jurassic Heritage? Geosciences 9: 343. https://doi.org/310.3390/ geosciences 9080343 .

Frasca G, Gueydan F, Brun JP, Monie P. 2016. Deformation mechanisms in a continental rift up to mantle exhumation. Field evidence from the western Betics, Spain. Marine and Petroleum Geology 76: 310-328. https://doi.org/310.1016/j.marpet geo.2016.1004.1020.

Frasca G, Gueydan F, Poujol M, Brun JP, Parat F, Monié P, et al. 2017. Fast switch from extensional exhumation to thrusting of the Ronda Peridotites (South Spain). Terra Nova 29: 117-126.

Frizon de Lamotte D, Andrieux J, Guézou JC. 1991. Cinématique des chevauchements Néogènes dans l'arc bético-Rifains, discussion sur les modèles géodynamiques. Bull Soc Géol Fr 4: 611-626.

Frizon de Lamotte D, Crespo-Blanc A, Saint-Bézar B, Comas M, Fernàndez M, Zeyen H, et al. 2004. Transect I: Iberia-Meseta - Guadalquivir Basin - Betic Cordillera - Alboran Sea - Rif Moroccan Meseta - High Atlas - Sahara Domain. In: Cavazza W, Roure FM, Spakman W, Stampfli GM, PAZ, Eds. The TRANSMED Atlas - The Mediterranean region from crust to Mantle. Berlin, Heidelberg: Springer.

Frizon de Lamotte D, Saint Bezar B, Bracène R, Mercier E. 2000. The two main steps of the Atlas building and geodynamics of the West Mediterranean. Tectonics 19: 740-761.

Frizon de Lamotte D, Zizi M, Missenard Y, Hafid M, El Azzouzi M, Charriere A, et al. 2008. The Atlas system. In: Michard A, Saddiqi O, Chalouan A, Frizon de Lamotte D, Eds. Continental Evolution: The Geology of Morocco. Heidelberg: Springer-Verlag, pp. 133-202.

Gansser A. 1981. The Geodynamic history of the Himalaya. In: Gupta HK, Delany FM, Eds. Zagros, Hindu Kush, Himalaya Geodynamic evolution. Washington DC: American Geophysical Union.
Garcia-Castellanos D, Villaseñor A. 2011. Messinian salinity crisis regulated by competing tectonics and erosion at the Gibraltar arc. Nature 480: 359-365. https://doi.org/310.1038/nature10651.

García-Dueñas V, Balanyá JC, Martínez-Martínez JM. 1992. Miocene extensional detachments in the outcropping basement of the Northern Alboran Basin (Betics) and their tectonic implications. Geol Mar Lett 12: 88-95.

García-Dueñas V, Martinez-Martinez JM, Orozco M, Soto JI. 1988. Plis-nappes, cisaillements syn-à post-metamorphiques et cisaillements ductiles-fragiles en distension dans les Nevado-Filábrides (Cordil- lères Bétiques, Espagne). C R Acad Sci Paris 307: 13891395.

García-Dueñas V, Navarro-Vila F. 1976. Alpujárride-Malaguides et autres unités allochtones au nord de la Sierra Nevada (Cordillères Bétiques, Andalousie). Bull Soc Géol Fr 18: 641-648.

Garrido CJ, Bodinier JL. 1999. Diversity of Mafic Rocks in the Ronda Peridotite: Evidence for Pervasive Melt-Rock Reaction during Heating of Subcontinental Lithosphere by Upwelling Asthenosphere. Journal of Petrology 40: 729-754

Garrido CJ, Gueydan F, Booth-Rea G, Précigout J, Hidas K, PadrónNavarta JA, et al. 2011. Garnet lherzolite and garnet-spinel mylonite in the Ronda peridotite: Vestiges of Oligocene backarc mantle lithospheric extension in the western Mediterranean. Geology 39: 927-930.

Gautier F, Clauzon G, Suc JP, Cravatte J, Violanti D. 1994. Age et durée de la crise de salinité messinienne. C R Acad Sci 318: 1103-1109.

Gimeno-Vives O, Mohn G, Bosse V, Haissen F, Zaghloul MN, Atouabat A, et al. 2019. The Mesozoic margin of the Maghrebian Tethys in the Rif belt (Morocco): Evidence for polyphase rifting and related magmatic activity. Tectonics 38: 2894-2918. https:// doi.org/2810.1029/2019TC005508.

Goffé B, Baronnet A, Morin G. 1994. La saliotite, interstratifié régulier 1:1 cookéite-paragonite. Un nouveau phyllosilicate du métamorphisme de haute pression et basse température. Eur $J$ Miner 6: 897-911.

Goffé B, Michard A, García-Dueñas V, Gonzales-Lodeiro F, Monié P, Campos J, et al. 1989. First evidence of high pressure, low temperature metamorphism in the Alpujárride nappes, Betic Cordillera (SE Spain). Eur J Miner 1: 139-142.

Gómez-Pugnaire MT, Fernandez-Soler JM. 1987. High pressure metamorphism in metabasites from the Betic Cordilleras (SE Spain) and its evolution during the Alpine orogeny. Contrib Mineral Petrol 95: 231-244.

Gómez-Pugnaire MT, Nieto F, Abad I, Velilla N, Garrido CJ, AcostaVigil A, et al. 2019. Alpine Metamorphism in the Betic Internal Zones. In: Quesada C, Oliveira JT, Eds. The Geology of Iberia: A Geodynamic Approach. Springer Nature Switzerland AG. https://doi.org/10.1007/1978-1003-1030-11295-11290_11213.

Gómez-Pugnaire MT, Rubatto D, Fernández-Soler JM, Jabaloy A, López-Sánchez-Vizcaíno V, González-Lodeiro F, et al. 2012. Late Variscan magmatism in the Nevado-Filábride Complex: U-Pb geochronologic evidence for the pre-Mesozoic nature of the deepest Betic complex (SE Spain). Lithos 146-147: 93-111. https://doi.org/110.1016/j.lithos.2012.1003.1027.

González-Jiménez JM, Marchesi C, Griffin WL, Gervilla F, Belousova EA, Garrido CJ, et al. 2017. Zircon recycling and crystallization during formation of chromite- and Ni-arsenide ores in the subcontinental lithospheric mantle (Serranía de Ronda, Spain). Ore Geology Review 90: 193-209. https://doi.org/ 110.1016/j.oregeorev.2017.1002.1012.

Gueydan F, Mazzotti S, Tiberi C, Cavin R, Villaseñor A. 2019. Western Mediterranean subcontinental mantle emplacement by continental margin obduction. Tectonics 38: 2142-2157. https:// doi.org/2110.1029/2018TC005058. 
Guillot S, Mahéo G, de Sigoyer J, Hattori KH, Pêcher, A. 2008. Tethyan and Indian subduction viewed from the Himalayan high- to ultrahigh-pressure metamorphic rocks. Tectonophysics 451: 255241.

Hidas K, Booth-Rea G, Garrido CJ, Martínez-Martínez JM, PadrónNavarta JA, Konc Z, et al. 2013. Backarc basin inversion and subcontinental mantle emplacement in the crust: kilometre-scale folding and shearing at the base of the proto-Alborán lithospheric mantle (Betic Cordillera, southern Spain). J Geol Soc Lond 170: 47-55.

Hidas K, Varas-Reus MI, Garrido CJ, Marchesi C, Acosta-Vigil A, Padrón-Navarta JA, et al. 2015. Hyperextension of continental to oceanic-like lithosphere: The record of late gabbros in the shallow subcontinental lithospheric mantle of the westernmost Mediterranean. Tectonophysics 650: 65-79. https://doi.org/10.1016/j. tecto.2015.1003.1011.

Hofmann AW, Giletti BJ, Hinthorne JR, Andersen CA, Comaford D. 1974. Ion microprobe analysis of a potassium self-diffusion experiment in biotite. Earth and Planetary Science Letters 24: 4852.

Homonnay E, Corsini M, Lardeaux JM, Romagny A, Münch P, Bosch $\mathrm{D}$, et al. 2018. Miocene crustal extension following thrust tectonic in the Lower Sebtides units (internal Rif, Ceuta Peninsula, Spain): Implication for the geodynamic evolution of the Alboran domain. Tectonophysics 722: 507-535. https://doi.org/510.1016/j. tecto.2017.1011.1028.

Hsü KJ, Cita MB, Ryan WBF. 1973. The origin of the Mediterranean evaporites. In: Ryan WFB, Hsü KJ, et al., Eds. Initial Reports of the Deep Sea Drilling Project. Washington: U.S. Government Printing Office, pp. 1203-1231.

Hsü KJ, Montadert L, Bernouilli D, Cita MB, Erickson A, Garrison RE, et al. 1978. History of the Messinian salinity crisis. In: Hsü KJ, Montadert L, et al., Eds. Initial Reports of the Deep Sea Drilling Project. Washington: U.S. Government Printing Office, pp. 10531078.

Iribarren L, Vergés J, Fernàndez M. 2009. Sediment supply from the Betic-Rif orogen to basins through Neogene. Tectonophysics 475: 68-84.

Jabaloy A, Galindo-Saldivar J, Gonzales-Lodeiro F. 1993. The Alpujárride-Nevado-Filábride extensional shear zone, Betic Cordillera, SE Spain. J Struct Geol 15: 555-569.

Janots E, Negro F, Brunet F, Goffé B, Engi M, Bouybaouène ML. 2006. Evolution of the REE mineralogy in HP-LT metapelites of the Sebtide complex, Rif, Morocco: Monazite stability and geochronology. Lithos 87: 214-234.

Janowski M, Loget N, Gautheron C, Barbarand J, Bellahsen N, Van Den Driessche J, et al. 2017. Neogene exhumation and relief evolution in the eastern Betics (SE Spain): Insights from the Sierra de Gador. Terra Nova: 1-7. https://doi.org/10.1111/ter.12252.

Johanesen K, Platt JP, Kaplan MS, Ianno AJ. 2014. A revised thermal history of the Ronda peridotite, S. Spain: New evidence for excision during exhumation. Earth and Planetary Science Letters 393:187-199. https://doi.org/110.1016/j.eps1.2014.1001.1024.

Johanesen KE, Platt JP. 2015. Rheology, microstructure, and fabric in a large scale mantle shear zone, Ronda Peridotite, southern Spain. Journal of Structural Geology 73: 1-17. https://doi.org/10.1016/j. jsg.2015.1001.1007.

Johnson C, Harbury N, Hurford AJ. 1997. The role of extension in the Miocene denudation of the Nevado-Filábrides Complex, Betic Cordillera (SE Spain). Tectonics 16: 189-204.

Jolivet L, Augier R, Faccenna C, Negro F, Rimmele G, Agard P, et al. 2008. Subduction, convergence and the mode of backarc extension in the Mediterranean region. Bull Soc Géol Fr 179: 525-550.
Jolivet L, Augier R, Robin C, Suc JP, Rouchy JM. 2006. The geodynamic context of the Messinian salinity crisis. Sedimentary Geology 188-189: 9-33.

Jolivet L, Brun JP. 2010. Cenozoic geodynamic evolution of the Aegean region. Int. J. Earth Science 99: 109-138. https://doi.org/ 110.1007/s00531-00008-00366-00534.

Jolivet L, Daniel JM, Truffert C, Goffé B. 1994. Exhumation of deep crustal metamorphic rocks and crustal extension in back-arc regions. Lithos 33: 3-30. https://doi.org/10.1016/0024-4937(1094) 90051-90055.

Jolivet L, Faccenna C. 2000. Mediterranean extension and the AfricaEurasia collision. Tectonics 19: 1095-1106. https://doi.org/ 1010.1029/2000TC900018.

Jolivet L, Faccenna C, Goffé B, Mattei M, Rossetti F, Brunet C, et al. 1998. Mid-crustal shear zones in post-orogenic extension: the northern Tyrrhenian Sea case. J. Geophys. Res. 103: 12123-12160. https://doi.org/12110.11029/12197JB03616.

Jolivet L, Faccenna C, Goffé B, Burov E, Agard P. 2003. Subduction tectonics and exhumation of high-pressure metamorphic rocks in the Mediterranean orogens. Am. J. Sci 303: 353-409. https://doi. org/310.2475/ajs.2303.2475.2353.

Jolivet L, Faccenna C, Huet B, Labrousse L, Le Pourhiet L, Lacombe O, et al. 2013. Aegean tectonics: Strain localisation, slab tearing and trench retreat. Tectonophysics 597-598: 1-33. https://doi.org/ 10.1016/j.tecto.2012.06.011.

Jolivet L, Gorini C, Smit J, Leroy S. 2015. Continental breakup and the dynamics of rifting in back-arc basins: The Gulf of Lion margin. Tectonics 34. https://doi.org/10.1002/2014TC003570.

Jolivet L, Trotet F, Monié P, Vidal O, Goffé B, Labrousse L, et al. 2010. Along-strike variations of P-T conditions in accretionary wedges and syn-orogenic extension, the HP-LT Phyllite-Quartzite Nappe in Crete and the Peloponnese. Tectonophysics 480: 133 148. https://doi.org/110.1016/j.tecto.2009.1010.1002.

Kirchner KL, Behr W, Loewy S, Stockli DF. 2016. Early Miocene subduction in the Western Mediterranean: constraints from $\mathrm{Rb}-\mathrm{Sr}$ multi-mineral isochron geochronology. Geochemistry, Geophysics, Geosystems. https://doi.org/10.1002/2015GC006208.

Kohn MK, Corrie SL, Markley C. 2015. The fall and rise of metamorphic zircon. American Mineralogist 100: 897-908. https:// doi.org/810.2138/am-2015-5064.

Kornprobst J. 1974. Contribution a l'etude petrographique et structurale de la zone interne du Rif (Maroc septentrional). Notes et Mémoires du Service Géologique, Rabat (Morocco) 251.

Kornprobst J. 1976. Signification structurale des péridotites dans l'orogène bético-rifain: arguments tirés de l'étude des détritus observés dans les sédiments paléozoïques. Bull. Soc. Géol. Fr XVIII, 607-618.

Kornprobst J, Durand-Delga M. 1985. Carte géologique du Maroc à 1/50 000: Sebta. Notes et Mém. Serv. géol. Maroc 297.

Kornprobst J, Piboule M, Roden M, Tabit A. 1990. Corundumbearing garnet clinopyroxenites at Beni Bousera (Morocco): original plagioclase-rich gabbros recrystallized at depth within the mantle. J. Petrol. 31: 717-745.

Kornprobst J, Vielzeuf D. 1984. Transcurrent crustal thinning: a mechanism for the uplift of deep continental crust/upper mantle associations. In: Kornprobst J, Ed. Kimberlites and related rocks. Elsevier, pp. 347-359.

Krijgsman W, Hilgen FJ, Marabini S, Vai GB. 1999. New paleomagnetic and cyclostratigraphic age constraints on the Messinian of the Northern Apennines (Vena del gesso Basin, Italy). Mem. Soc. Geol. It. 54: 25-33.

Lafosse M, d'Acremont E, Rabaute A, Estrada F, Jollivet-Castelot M, Vazquez JT, et al. 2020. Plio-Quaternary tectonic evolution of the 
southern margin of the Alboran Basin (Western Mediterranean). Solid Earth 11: 741-765. https://doi.org/710.5194/se-5111-57412020.

Lagabrielle Y, Asti R, Fourcade S, Corre B, Labaume P, Uzel J, et al. 2019a. Mantle exhumation at magma-poor passive continental margins. Part II: Tectonic and metasomatic evolution of largedisplacement detachment faults preserved in a fossil distal margin domain (Saraillé lherzolites, northwestern Pyrenees, France). BSGF - Earth Sciences Bulletin 190: 14. https://doi.org/10.1051/bsgf/ 2019013.

Lagabrielle Y, Asti R, Fourcade S, Corre B, Poujol M, Uzel J, et al. 2019b. Mantle exhumation at magma-poor passive continental margins. Part I. 3D architecture and metasomatic evolution of a fossil exhumed mantle domain (Urdach lherzolite, north-western Pyrenees, France). BSGF - Earth Sciences Bulletin 190: 8. https:// doi.org/10.1051/bsgf/2019007.

Lagabrielle Y, Bodinier JL. 2008. Submarine reworking of exhumed subcontinental mantle rocks: field evidence from the Lherz peridotites, French Pyrenees. Terra Nova 20: 11-21. https://doi. org/10.1111/j.1365-3121.2007.00781.x.

Lahfid A, Beyssac O, Deville E, Negro F, Chopin C, Goffé B. 2010. Evolution of the Raman spectrum of carbonaceous material in low-grade metasediments of the Glarus Alps (Switzerland). Terra Nova 22: 354-360. https://doi.org/310.1111/ j.1365-3121.2010.00956.x.

Laurent V, Lanari P, Nair I, Augier R, Lahfid A, Jolivet L. 2018. Exhumation of eclogite and blueschist (Cyclades, Greece): Pressure-temperature evolution determined by thermobarometry and garnet equilibrium modeling. J Metam Geol 36: 769-798. https://doi.org/710.1111/jmg.12309.

Lavier LL, Buck WR, Poliakov ANB. 1999. Self-consistent rollinghinge model for the evolution of large-offset low-angle normal faults. Geology 27: 1127-1130.

Lenoir X, Garrido CJ, Bodinier JL, Dautria JM, Gervilla F. 2001. The recrystallization front of the Ronda peridotite: Evidence for melting an thermal erosion of subcontinental lithospheric mantle beneath the Alboran Basin. J. Petrol. 42: 141-158

Leprêtre R, Frizon de Lamotte D, Combier V, Gimeno-Vives O, Mohn G, Eschard R. 2018. The Tell-Rif orogenic system (Morocco, Algeria, Tunisia) and the structural heritage of the southern Tethys margin. BSGF - Earth Sciences Bulletin 189: 10. https://doi.org/ $10.1051 / \mathrm{bsgf} / 2018009$.

Li B, Massonne HJ. 2018. Two Tertiary metamorphic events recognized in high-pressure metapelites of the Nevado-Filábride Complex, (Betic Cordillera, S,Spain). J Metam Geol 36: 603-630.

Lonergan L. 1993. Timinig and kinematics of deformation in the Malaguide Complex, internal zone of the Betic Cordillera, southeast Spain. Tectonics 12: 460-476.

Lonergan L, Platt JP. 1995. The Malaguide-Alpujárride boundary: a major extensional contact in the internal zones of the eastern Betic Cordillera, SE Spain. J Struct Geol 17: 1655-1671.

Lonergan L, White N. 1997. Origin of the Betic-Rif mountain belt. Tectonics 16: 504-522.

Loomis TP. 1975. Tertiary mantle diapirism, orogeny, and plate tectonics east of the Strait of Gibraltar. Am J Sci 275: 1-30.

Loomis TP. 1972a. Contact metamorphism of pelitic rocks by the Ronda peridotite ultramafic intrusion, Southern Spain. Geol Soc Am Bull 83: 2449-2474.

Loomis TP. 1972b. Diapiric emplacement of the Ronda hightemperature ultramafic intrusion, Southern Spain. Geol Soc Am Bull 83: 2475-2496.

López Sánchez-Vizcaíno V, Rubatto D, Gómez-Pugnaire MT, Trommsdorff V, Müntener O. 2001. Middle Miocene high-pressure metamorphism and fast exhumation of the Nevado-Filábride complex, SE Spain. Terra Nova 13: 327-332.

Lundeen MT. 1978. Emplacement of the Ronda peridotite, Sierra Bermeja, Spain. Geol Soc Am Bull 89: 172-180.

MacLeod CJ, Searle RC, Murton BJ, Casey JF, Mallows C, Unsworth SC, et al. 2009. Life cycle of oceanic core complexes. Earth and Planetary Science Letters 287: 333-344. https://doi.org/310.1016/ j.eps1.2009.1008.1016.

Malinverno A, Ryan W. 1986. Extension in the Tyrrhenian sea and shortening in the Apennines as result of arc migration driven by sinking of the lithosphere. Tectonics 5: 227-245.

Malusa MG, Faccenna C, Baldwin SL, Fitzgerald PG, Rossetti F, Balestrieri ML, et al. 2015.Contrasting styles of (U)HP rock exhumation along the Cenozoic Adria- Europe plate boundary (Western Alps, Calabria, Corsica). Geochem. Geophys. Geosyst. 16: 1786-1824. https://doi.org/1710.1002/2015GC005767.

Martín-Algarra A, Andreo B, Balanyá JC, Estévez A, López-Garrido AC, O’Dogherty L, et al. 2004. Unidades Frontales de las Zonas Internas. In: Vera JA, Ed. Geología de España, Chap. 4. Cordillera Bética y BalearesSociedad Geológica de España. Madrid: Instituto Geológico y Minero de España, pp. 396-401.

Martínez-García P, Comas M, Lonergan L, Watts AB. 2017. From extension to shortening: Tectonic inversion distributed in time and space in the Alboran sea, western Mediterranean. Tectonics 36: 2777-2805. https://doi.org/2710.1002/2017TC004489.

Martínez-García P, Comas M, Soto JI, Lonergan L, Watts AB. 2013. Strike-slip tectonics and basin inversion in the Western Mediterranean: the Post-Messinian evolution of the Alboran Sea. Basin Research 25: 361-387. https://doi.org/310.1111/bre.12005.

Martínez-Martínez J, Soto J, Balanyá J. 1997. Large scale structures in the Nevado-Filáride Complex and crustal seismic fabrics of the deep seismic reflection profile ESCI-Béticas 2. Bol Soc Geol Esp 8: $477-489$.

Martinez-Martinez JM, Azañón JM. 1997. Mode of extensional tectonics in the southeastern Betics (SE Spain): implications for the tectonic evolution of the peri-Alboran orogenic system. Tectonics 16: $205-225$.

Martinez-Martinez JM, Azañón JM. 2002. Orthogonal extension in the hinterland of the Gibraltar Arc (Betics, SE Spain). In: Rosenbaum G, Lister GS, Eds. Reconstruction of the evolution of the Alpine-Himalayan Orogen, pp. 3-22.

Martínez-Martínez JM, Soto JI, Balanyá JC. 2002. Orthogonal folding of extensional detachments: structure and origin of the Sierra Nevada elongated dome (Betics, SE Spain). Tectonics 21. https://doi.org/10.1029/2001TC001283.

Martínez-Martínez JM, Soto JI, Balanyá JC. 2002. Orthogonal folding of extensional detachments: structure and origin of the Sierra Nevada elongated dome (Betics, SE Spain). Tectonics 21. https://doi.org/10.1029/2001TC001283.

Martínez-Martínez JM, Soto JI, Balanyá JC. 2004. Elongated domes in extended orogens: A mode of mountain uplift in the Betics (southeast Spain). In: Whitney DL, Teyssier C, Siddoway CS, Eds. Gneiss domes in orogeny. Boulder, Colorado: Geological Society of America Special Paper, 380, pp. 243-266.

Massonne HJ. 2014. Wealth of P-T-t information in medium-high grade metapelites: Example from the Jubrique Unit of the Betic Cordillera, S Spain. Lithos 208-209: 137-157. https://doi.org/ 110.1016/j.lithos.2014.1008.1027.

Maury RC, Fourcade S, Coulonc C, El Azzouzia M, Bellona H, Coutelle A, et al. 2000. Post-collisional Neogene magmatism of the Mediterranean Maghreb margin: a consequence of slab breakoff. C R Acad Sci Paris, Sciences de la Terre et des planètes/Earth and Planetary Sciences 331: 159-173. 
Mazzoli S, Martin-Algarra A. 2011. Deformation partitioning during transpressional emplacement of a 'mantle extrusion wedge': the Ronda peridotites, western Betic Cordillera, Spain. Journal of the Geological Society, London 168: 373-382. https://doi.org/ 310.1144/0016-76492010-76492126.

Mazzoli S, Martin-Algarra A, Reddy SM, Lopez Sanchez-Vizcaino V, Fedele L, Noviello A. 2013. The evolution of the footwall to the Ronda subcontinental mantle peridotites: insights from the Nieves Unit (western Betic Cordillera). Journal of the Geological Society, London 170: 385-402. https://doi.org/310.1144/jgs2012-1105.

Meijninger BML, Vissers RLM. 2006. Miocene extensional basin development in the Betic Cordillera, SE Spain revealed through analysis of the Alhama de Murcia and Crevillente Faults. Basin Research 18: 547-571. https://doi.org/510.1111/ j.1365-2117.2006.00308.x.

Michard A, Chalouan A, Feinberg H, Goffé B, Montigny R. 2002. How does the Alpine belt end between Spain and Morocco? Bull Geol Soc Fr 173: 3-15.

Michard A, Goffé B, Bouybaouene ML, Saddiqi O. 1997. Late Hercynian \pm Mesozoic thinning in the Alboran domain: metamorphic data from the northern Rif, Morocco. Terra Nova 9: 171-174.

Michard A, Goffé B, Chalouan A, Saddiqi A. 1991. les corrélations entre les chaînes bético-rifaines et les Alpes et leurs conséquences. Bull Soc Géol Fr 162: 1151-1160.

Michard A, Mokhtari A, Chalouan A, Saddiqi O, Rossi P, Rjimati EC. 2014. New ophiolite slivers in the External Rif belt, and tentative restoration of a dual Tethyan suture in the western Maghrebides. Bull Soc Géol Fr 185: 313-328.

Michard A, Negro F, Saddiqi O, Bouybaouene ML, Chalouan A, Montigny $\mathrm{R}$, et al. 2006. Pressure-temperature-time constraints on the Maghrebide mountain building: evidence from the Rif-Betic transect (Morocco, Spain), Algerian correlations, and geodynamic implications. C R Geosci 338: 92-114.

Michard A, Saddiqi O, Chalouan A, Chabou MC, Lach P, Rossi P. 2020. Comment on "The Mesozoic margin of the Maghrebian Tethys in the Rif Belt (Morocco): Evidence for poly- phase rifting and related magmatic activity" by Gimeno-Vives et al. Tectonics 39. https://doi.org/10.1029/2019TC006004.

Monié P, Lodeiro FG, Goffé B, Jabaloy A. 1991. 39Ar/40Ar geochronology of alpine tectonism in the Betic Cordillera (Southern Spain). J Geol Soc London 148: 289-297.

Monié P, Torres-Roldán RL, García-Casco A. 1994. Cooling and exhumation of the Wertern Betic Cordilleras, 40Ar/39Ar thermochronological constraints on a collapsed terrane. Tectonophysics 238: 353-379.

Montel JM, Kornprobst J, Vielzeuf D. 2000. Preservation of old U$\mathrm{Th}-\mathrm{Pb}$ ages in shielded monazite: example from the Beni Bousera Hercynian kinzigites (Morocco). J Metamorph Geol 18: 335-342.

Montenat C, Ott d'Estevou P. 1990. Eastern betic Neogene Basins - A review. In: Montenat $\mathrm{C}$, Ed. Les Bassins Neogenes du Domaine Bétique Oriental (Espagne) 12-13. Documents et Travaux IGAL, pp. 9-15.

Montenat C, Ott d'Estevou P. 1999. The diversity of Late Neogene sedimentary basins generated by wrench faulting in the Eastern Betics Cordillera, SE Spain. Journal of Petroleum Geology 22: 61-80.

Mouthereau F, Filleaudeau PY, Vacherat A, Pik R, Lacombe O, Fellin MG, et al. 2014. Placing limits to shortening evolution in the Pyrenees: Role of margin architecture and implications for the Iberia/Europe convergence. Tectonics 33: 2283-2314. https://doi. org/2210.1002/2014TC003663.

Negro F, Rimmelé G, Jolivet L, Augier R, Goffé B, Azañón JM. 2005. Tectonic and metamorphic evolution of the Alpujárride Complex in
Central and Eastern Betics (Alboran Domain, SE Spain). Tectonics (submitted).

Negro F, Beyssac O, Goffé B, Saddiqi O, Bouybaouène ML. 2006. Thermal structure of the Alboran domain in the Rif (northern Morocco) and the Western Betics (southern Spain). Constraints from raman spectroscopy of carbonaceous material. J Metam Geol. https://doi.org/10.1111/j.1525-1314.2006.00639.x.

Nijhuis HJ. 1964. Plurifacial alpine metamorphism in the southeastern Sierra de los Filabres south of Lubrin, Amsterdam.

Obata M. 1980. The Ronda Peridotite: Garnet-, Spinel-, and Plagioclase-Lherzolite Facies and the $\mathrm{P}-\mathrm{T}$ Trajectories of a High-Temperature Mantle Intrusion. Journal of Petrology 21: 533 572.

Olivier P, Paquette JL. 2018. Early Permian age of granite pebbles from an Eocene or Oligocene conglomerate of the Internal Rif belt (Alboran domain, Morocco): hypothesis on their origin. BSGF Earth Sciences Bulletin 189: 13. https://doi.org/10.1051/bsgf/ 2018012.

Oncken O, Chong G, Franz G, Giese P, Götze HJ, Ramos VA, et al. 2006. The Andes: Active Subduction Orogeny. Springer.

Palomeras I, Villaseñor A, Thurner S, Levander A, Gallart J, Harnafi M. 2017. Lithospheric structure of Iberia and Morocco using finitefrequency Rayleigh wave tomography from earthquakes and seismic ambient noise. Geochem. Geophys. Geosyst.: Q01005. https://doi.org/10.1029/2003GC00061418:1824-1840. https://doi. org/1810.1002/2016GC006657.

Parra T, Vidal O, Jolivet L. 2002. Relation between deformation and retrogression in blueschist metapelites of Tinos island (Greece) evidenced by chlorite-mica local equilibria. Lithos 63: 41-66. https://doi.org/10.1016/S0024-4937(1002)00115-00119.

Pearson DG, Davies GR, Nixon PH, Milledge HJ. 1989. Graphitized diamonds from a peridotite massif in Morocco and implications for anomalous diamond occurrences. Nature 338: 60-62.

Pearson DG, Nowell GM. 2004. Re-Os and Lu-Hf Isotope Constraints on the Origin and Age of Pyroxenites from the Beni Bousera Peridotite Massif: Implications for Mixed Peridotite-Pyroxenite Mantle Sources. Journal of Petrology 45: 439-455. https://doi.org/ 2010.1093/petrology/egg2102.

Pedrera A, Ruiz-Constán A, García-Senz J, Azor A, Marín-Lechado C, Ayala C, et al. 2020. Evolution of the South-Iberian paleomargin: From hyperextension to continental subduction. Journal of Structural Geology 138: 104122. https://doi.org/ 10.1016/j.jsg.2020.104122.

Pedrera A, Galindo-Zaldívar J, Tello A, Marín-Lechadoa C. 2010. Intramontane basin development related to contractional and extensional structure interaction at the termination of a major sinistral fault: The Huércal-Overa Basin (Eastern Betic Cordillera). Journal of Geodynamics 49: 271-286.

Picazo S, Cannat M, Delacour A, Escartín J, Rouméjon S, Silantyev S. 2012. Deformation associated with the denudation of mantlederived rocks at the Mid-Atlantic Ridge $13^{\circ}-15^{\circ} \mathrm{N}$ : The role of magmatic injections and hydrothermal alteration. Geochem Geophys Geosyst 13: Q04G09. https://doi.org/10.1029/ 2012GC004121.

Picazo S, Manatschal G, Cannat M, Andréani M. 2013. Deformation associated to exhumation of serpentinized mantle rocks in a fossil Ocean Continent Transition: The Totalp unit in SE Switzerland. Lithos 175-176: 255-271. https://doi.org/210.1016/j.lith os.2013.1005.1010.

Piles Mateo E, Chamon Cobos C, Estevez Gonzales C, Crespo V, Aguilar M, Reyes KL. 1973. Marbella, Mapa Geologico de España, escala 1:50.000, 1065. IGME. 
Pindell J, Kennan L, Stanek KP, Maresch WV, Draper G. 2006. Foundations of Gulf of Mexico and Caribbean evolution: eight controversies resolved. Geologica Acta: An International Earth Science Journal 4: 303-341.

Platt JP. 1986. Dynamics of orogenic wedges and the uplift of highpressure metamorphic rocks. Geological Society of America Bulletin 97: 1037-1053.

Platt JP, Allerton S, Kirker A, Mandeville C, Mayfield A, Platzman ES, et al. 2003a. The ultimate arc: differential displacement, oroclinal bending, and vertical axis rotation in the external BeticRif arc. Tectonics 22: 1017. https://doi.org/1010.1029/ 2001 TC001321.

Platt JP, Anczkiewicz R, Soto JI, Kelley SP, Thirlwall M. 2006. Early Miocene continental subduction and rapid exhumation in the Western Mediterranean. Geology 34: 981-984. https://doi.org/ 910.1130/G22801A22801.

Platt JP, Argles TW, Carter A, Kelley SP, Whitehouse MJ, Lonergan L. 2003b. Exhumation of the Ronda peridotite and its crustal envelope: constraints from thermal modelling of a P-T-time array. Journal of the Geological Society 160: 655-676.

Platt JP, Behr WM, Johanesen K, Williams JR. 2013. The Betic-Rif Arc and Its Orogenic Hinterland: A Review. Annu Rev Earth Planet Sci 41: 313-357. 310.1146/annurev-earth-050212-123951.

Platt JP, Kelley SP, Carter A, Orozco M. 2005. Timing of tectonic events in the Alpujárride Complex, Betic Cordillera, S. Spain. Journal of the Geological Society, London 162: 1-12.

Platt JP, Soto JI, Whitehouse MJ, Hurford AJ, Kelley SP. 1998. Thermal evolution, rate of exhumation, and tectonic significance of metamorphic rocks from the floor of the Alboran extensional basin, western Mediterranean. Tectonics 17: 671-689.

Platt JP, Vissers RLM. 1989. Extensional collapse of thickened continental lithosphere: A working hypothesis for the Alboran Sea and Gibraltar arc. Geology 17: 540-543.

Platt JP, Whitehouse MJ. 1999. Early Miocene high-temperature metamorphism and rapid exhumation in the Betic Cordillera (Spain): evidence from U-Pb zircon ages. Earth Planet Sci Lett 171: 591-605.

Platt JP, Whitehouse MJ, Kelley SP, Carter A, Hollick L. 2003c. Simultaneous extension exhumation across the Alboran Basin: implications for the causes of late orogenic extension. Geology 31: 251-254.

Prada M, Ranero CR, Sallarès V, Zitellini N, Grevemeyer I. 2016. Mantle exhumation and sequence of magmatic events in the Magnaghi-Vavilov Basin (Central Tyrrhenian, Italy): New constraints from geological and geophysical observations. Tectonophysics 689: 133-142. https://doi.org/110.1016/j.tecto.2016.1001.1041.

Précigout J, Gueydan F, Gapais D, Garrido CJ, Essaifi A. 2007. Strain localisation in the sub-continental mantle-A ductile alternative to the brittle mantle. Tectonophysics 445: 318-336.

Précigout J, Gueydan F, Garrido CJ, Cogné N, Booth-Rea G. 2013. Deformation and Exhumation of the Ronda peridotite (Spain). Tectonics 32: 1011-1025. https://doi.org/1010.1002/tect.20062.

Précigout J, Prigent C, Palasse L, Pochon A. 2017. Water pumping in mantle shear zones. Nat. Commun. 8: 15736. https://doi.org/ 15710.11038/ncomms 15736 .

Priem HNA, Boelrijk NAIM, Hebeda EH, Oen IS, Verdurmen EAT, Verschure RH. 1979. Isotopic dating of the emplacement of the ultramafic masses in the Serrania de Ronda, Southern Spain. Contrib Miner Pet 70: 103-109.

Puga E, Diaz de Federico A, Demant A. 1995. The eclogitized pillows of the Betic Ophiolitic Association: relics of the Tethys Ocena floor incorporated in the Alpine chain after subduction. Terra Nova 7: $31-43$.
Puga E, Díaz de Federico A, Fanning M, Nieto JM, Rodríguez Martínez-Conde JA, et al. 2017. The Betic Ophiolites and the Mesozoic Evolution of the Western Tethys. Geosciences 7: 31. https://doi.org/10.3390/geosciences7020031.

Puga E, Nieto JM, Díaz de Federico A. 2000. Contrasting P-T paths in eclogites of the Betic ophiolitic association, Mulhacen Complex, South-eastern Spain. Canadian Mineralogist 38: 1137-1161.

Puga E, Diaz de Federico A, Nieto JM. 2002. Tectonostratigraphic subdivision and petrological characterisation of the deepest complexes of the Betic zone: a review. Geodinamica Acta 15: 23-43.

Puga E, Nieto JM, Díaz de Federico A. 2000. Contrasting P-T paths in eclogites of the Betic ophiolitic association, Mulhacen Complex, South-eastern Spain. Canadian Mineralogist 38: 1137-1161.

Puga E, Nieto JM, Diaz de Federico A, Bodinier JL, Morten L. 1999. Petrology and metamorphic evolution of ultramafic rocks and dolerite dykes of the Betic Ophiolitic Association (Mulhacen Complex, SE Spain): evidence of eo-Alpine subduction following an ocean-floor metasomatic process. Lithos 49: 23-56.

Quintana L, Pulgar JA, Alonso JL. 2015. Displacement transfer from borders to interior of a plate: A crustal transect of Iberia. Tectonophysics 663: 378-398. https://doi.org/310.1016/j. tecto.2015.1008.1046.

Ramos A, Fernández O, Torne M, Sánchez de la Muela A, Muñoz JA, Terrinha P, et al. 2017. Crustal structure of the SW Iberian passive margin: The westernmost remnant of the Ligurian Tethys? Tectonophysics 705: 42-62. https://doi.org/10.1016/j. tecto.2017.1003.1012.

Rat J, Mouthereau F, Brichau S, Crémades A, Bernet M, Balvay M. 2019. Tectonothermal evolution of the Cameros basin: Implications for tectonics of North Iberia. Tectonics 38: 440-469. https://doi. org/410.1029/2018TC005294.

Reuber I, Michard A, Chalouan A, Juteau T, Jermoumi B. 1982. Structure and emplacement of the Alpine-type peridotites from Beni Bousera, Rif, Morocco: a polyphase tectonic interpretation. Tectonophysics 82: 231-251.

Roca E, Guimerà J. 1992. The Neogene structure of the eastern Iberian margin: structural constraints on the crustal evolution of the Valencia trough (western Mediterranean). Tectonophysics 203: 203-218.

Romagny A, Jolivet L, Menant A, Bessière E, Maillard A, Canva A, et al. 2020. Detailed tectonic reconstructions of the Western Mediterranean region for the last $35 \mathrm{Ma}$, insights on driving mechanisms. BSGF-Earth Sciences Bulletin 37. https://doi.org/ $10.1051 / \mathrm{bsgf} / 2020040$.

Rosenbaum G, Lister GS, Duboz C. 2002. Reconstruction of the tectonic evolution of the western Mediterranean since the Oligocene. Journal of the Virtual Explorer 8: 107-126.

Rossetti F, Dini A, Lucci F, Bouybaouenne M, Faccenna C. 2013. Early Miocene strike-slip tectonics and granite emplacement in the Alboran Domain (Rif Chain, Morocco): significance for the geodynamic evolution of Western Mediterranean. Tectonophysics 608: 774-791. https://doi.org/710.1016/j.tecto.2013.1008.1002.

Rossetti F, Faccenna C, Crespo-Blanc A. 2005. Structural and kinematic constraints of the Alpujárride complex (Central Betic Cordillera, Spain). J Struct Geol 27: 199-216.

Rossetti F, Lucci F, Theye T, Bouybaouenne M, Gerdes A, Opitz J, et al. 2020. Hercynian anatexis in the envelope of the Beni Bousera peridotites (Alboran Domain, Morocco): Implications for the tectono-metamorphic evolution of the deep crustal roots of the Mediterranean region. Gondwana Research (in press). https://doi. org/10.1016/j.gr.2020.1001.1020. 
Rossetti F, Theye T, Lucci F, Bouybaouene ML, Dini A, Gerdes A, et al. 2010. Timing and modes of granite magmatism in the core of the Alboran Domain (Rif chain, northern Morocco): implications for the Alpine evolution of the western Mediterranean. Tectonics 29: TC2017. https://doi.org/2010.1029/2009TC002487.

Ruiz-Cruz MD, Sanz de Galdeano C. 2014. Garnet variety and zircon ages in UHP meta-sedimentary rocks from the Jubrique zone (Alpujárride Complex, Betic Cordillera, Spain): evidence for a pre-Alpine emplacement of the Ronda peridotite. Int Geol Rev 56: 845-868.

Saddiqi O, Reuber I, Michard A. 1988. Unroofing of the continental upper mantle in the beni Bousera, Norther Rif, Morocco. C R Acad Sci Paris 307: 657-662.

Salas R, Casas A. 1993. Mesozoic extensional tectonics, stratigraphy and crustal evolution during the Alpine cycle of the eastern Iberian basin. Tectonophysics 228: 33-55. https://doi.org/10.1016/ 0040-1951(1093)90213-90214.

Salas R, Guimerà J, Mas R, Martín-Closas C, Melendez A, Alonso A. 2001. Evolution of the Mesozoic central Iberian rift system and its Cainozoic inversion (Iberian chain). Memoires Du Museum National d'Histoire Naturelle 186: 145-186.

Sanchez-Rodriguez L, Gebauer D, Tubia JM, Gil Ibarguchi JI, Rubatto D. 1996. First schrimp-ages on pyroxenite, eclogites and granites of the Ronda complex and its country-rocks. Geogaceta 20: 487-489.

Sánchez-Gómez M, Azañón JM, García-Dueñas V, Soto JI. 1999. Correlation between metamorphic rocks recovered from Site 976 and the Alpujárride rocks of the western Betics. In: Zahn R, Comas MC, Klaus A, Eds. Proccedings of the Ocean Drilling Program, Scientific results. College Station, TX, pp. 307-317.

Sánchez-Navas A, García-Casco A, Algarra AMN. 2014. Pre-Alpine discordant granitic dikes in the metamorphic core of the Betic Cordillera: tectonic implications. Terra Nova 26: 477-486.

Sánchez-Navas A, García-Casco A, Mazzoli S, Martín-Algarra A. 2017. Polymetamorphism in the Alpujárride Complex, Betic Cordillera, South Spain. The Journal of Geology 125: 10.1086/ 693862.

Sánchez-Rodríguez L, Gebauer D. 2000. Mesozoic formation of pyroxenites and gabbros in the Ronda area (southern Spain), followed by Early Miocene subduction metamorphism and emplacement into the middle crust: $\mathrm{U}-\mathrm{Pb}$ sensitive high-resolution ion microprobe dating of zircon. Tectonophysics 316: 19-44.

Santamaria-Lopez A, Lanari P, Sanz de Galdeano C. 2019. Deciphering the tectono-metamorphic evolution of the NevadoFilábride complex (Betic Cordillera, Spain) - A petrochronological study. Tectonophysics 767(2019) 128-158.

Sanz de Galdeano C. 2017. Implication of the geology of the Guadaiza and Verde valleys (Malaga Province, Betic Cordillera) on the position of the Ronda peri- dotites and the structure of the Alpujárride Complex. Boletín Geológico y Minero 128: 989-1006. https://doi.org/1010.21701/bolgeomin.21128.21704.21006.

Sanz de Galdeano C, Vera JA. 1992. Stratigraphic record and paleogeographical context of the Neogene basins in the Betic Cordillera, Spain. Basin Research 4: 21-36.

Sanz de Galdeano C, Andreo B. 1995. Structure of Sierra Blanca (Alpujárride complex, west of the Betic Cordillera). Estudios Geol 51: 43-55.

Sautkin A, Talukder AR, Comas MC, Soto JI, Alekseev A. 2003. Mud volcanoes in the Alboran Sea: evidence from micropaleontological and geophysical data. Marine Geology 195: 237-261.

Scherer EE, Cameron KL, Blichert-Toft J. 2000. Lu-Hf garnet geochronology: Closure temperature relative to the Sm-Nd system and the effects of trace mineral inclusions. Geochimica et Cosmochimica Acta 64: 3413-3432.
Searle MP, Windley BF, Coward MP, Cooper DJW, Rex AJ, Li T, et al. 1987. The closing of Tethys and the tectonics of the Himalaya. Geol Soc Am Bull 9: 678-701.

Selverstone J, Spear FS. 1985. Metamorphic P-T paths from pelitic schists and greenstones from the south-west Tauern Window. Journal of Metamorphic Geology 3: 439-465.

Serrano F, Sanz de Galdeano C, El Kadiri K, Guerra-Merchan A, Lopez-Garrido AC, Martin-Martin L, et al. 2006. Oligocene-early Miocene transgressive cover of the Betic-Rif Internal Zone. Revision of its geologic significance. Eclogae Geol Helv 99: 237 253. https://doi.org/210.1007/s00015-00006-01186-00019.

Simancas JF, Campos J. 1993. Compresión NNW-SSE tardi- a postmetamórfica y extensión subordinada en el Complejo Alpujárride (Dominio de Alborán, Orógeno bético). Revista de la Società Geolologica de España 6: 23-36.

Simon O, Westerhof A, Rondeel H. 1976. A propos d'une nouvelle paléogéographie de la zone bétique (Espagne méridionale); implications géodynamiques. Bull Soc Géol France 18: 601605.

Soret M, Agard P, Dubacq B, Plunder A, Yamato P. 2017. Petrological evidence for stepwise accretion of metamorphic soles during subduction infancy (Semail ophiolite, Oman and UAE). Journal of Metamorphic Geology 35: 1051-1080. https://doi.org/1010.1111/ jmg. 12267.

Sosson M, Morillon AC, Bourgois J, Feraud G, Poupeau G, SaintMarc P. 1998. Late exhumation stages of the Alpujárride Complex (western Betic Cordilleras, Spain): new thermochronological and structural data on Los Reales and Ojén nappes. Tectonophysics 285: 253-273.

Soto JI, Flinch J, Tari G. 2017. Permo-Triassic Salt Provinces of Europe, North Africa and the Atlantic Margins. Tectonics and Hydrocarbon Potential. Amsterdam: Elsevier, 632 p.

Soto JI, Platt JP. 1999. Petrological and structural evolution of highgrademetamorphic rocks from the floor of the Alboran Sea basin, Western Mediterranean. J Petrol 40: 21-60.

Spakman W, Wortel R. 2004. A tomographic view on Western Mediterranean geodynamics. In: Cavazza W, Roure FM, Spakman W, Stampfli GM, Ziegler PA, Eds. The TRANSMED Atlas - The Mediterranean region from crust to Mantle. Berlin, Heidelberg: Springer, pp. 31-52.

Teixell A, Labaume P, Ayarza P, Espurt N, de Saint Blanquat M, Lagabrielle Y. 2018. Crustal structure and evolution of the Pyrenean-Cantabrian belt: A review and new interpretations from recent concepts and data. Tectonophysics 724-725: 146-170. https://doi.org/110.1016/j.tecto.2018.1001.1009.

Torres-Roldán R. 1979. The tectonic subdivision of the Betic Zone (Betic Cordilleras, Southern Spain): its significance and one possible geotectonic scenario for the westernmost Alpine belt. Am J Sci 279.

Trotet F, Goffé B, Vidal O, Jolivet L. 2006. Evidence of retrograde $\mathrm{Mg}$-carpholite in the Phyllite-Quartzite nappe of Peloponnese from thermobarometric modelisation - geodynamic implications. Geodinamica Acta 19: 323-343.

Tubía JM, Cuevas J. 1986. High-temperature emplacement of the Los Reales peridotite nappe (Betic Cordillera, Spain). Journal of Structural Geology 8: 473-482.

Tubía JM, Cuevas J, Esteban JJ. 2004. Tectonic evidence in the Ronda peridotites, Spain, for mantle diapirism related to delamination. Geology 32: 941.

Tubía JM, Cuevas J, Ibarguchi JG. 1997. Sequential development of the metamorphic aureole beneath the Ronda peridotites and its bearing on the tectonic evolution of the Betic Cordillera. Tectonophysics 279: 227-252. 
Tubía JM, Gil Ibarguchi JI. 1991. Eclogites of the Ojén nappe: a record of subduction in the Apujarride complex (Betic Cordilleras, southern Spain). Journal of the Geological Society, London 148: 801-804.

Valetti L, Rutter E, McCabe A, Mecklenburgh J. 2019. On the structure and evolution of the Sorbas basin, S.E. Spain. Tectonophysics 773: 228230. https://doi.org/228210.221016/j. tecto.222019.228230.

Van der Wal D, Bodinier JL. 1996. Origin of the recrystallisation front in the Ronda peridotite by $\mathrm{km}$-scale pervasive porous melt flow. Contrib Mineral Petrol 122: 387-405.

van der Wal D, Vissers RLM. 1996. Structural Petrology of the Ronda Peridotite, SW Spain: Deformation History. Journal of Petrology 37: 23-43.

van Hinsbergen DJJ, Vissers RLM, Spakman W. 2014. Origin and consequences of western Mediterranean subduction, rollback, and slab segmentation. Tectonics 33: 393-419. https://doi.org/ $310.1002 /$ tect. 20125 .

van Hinsbergen DJJ, Torsvik TH, Schmid SM, Maţenco LC, Maffione M, Vissers RLM, et al. 2019. Orogenic architecture of the Mediterranean region and kinematic reconstruction of its tectonic evolution since the Triassic. Gondwana Research (in press). https:// doi.org/10.1016/j.gr.2019.1007.1009.

Vauchez A, Nicolas A. 1991. Mountain building: strike-parallel motion and mantle anisotropy. Tectonophysics 185: 183-201

Vergés J, Fernàndez M. 2012. Tethys-Atlantic interaction along the Iberia-Africa plate boundary: The Betic-Rif orogenic system. Tectonophysics 579: 144-172. https://doi.org/110.1016/j. tecto.2012.1008.1032.

Vergés J, Sabat F. 1999. Contraints on the western Mediterranean kinematic evolution along a $1000 \mathrm{~km}$ transect, from Iberia to Africa. In: Dur B, Jolivet L, Horvath F, Séranne M, Eds. The Mediterranean basins: Tertiary extension within the Alpine orogen. London: Geological Society, pp. 63-80.

Vidal O, Goffé B, Bousquet R, Parra T. 1999. Calibration and testing of an empirical chloritoid-chlorite $\mathrm{Mg}-\mathrm{Fe}$ exchange thermometer and thermodynamic data for daphnite. J Metamorphic Geol 17: 25-39.

Vidal O, Parra T. 2000. Exhumation paths of high pressure metapelites obtained from equilibria for chlorite-phengite assemblages. Geol J 35: 139-161.

Vissers RLM, Platt JP, Van der Wal D. 1995. Late orogenic extension of the Betic Cordillera and the Alboran domain: a lithospheric view. Tectonics 14: 786-803.
Weijermars R. 1991. Geology and tectonics of the Betic Zone, SE Spain. Earth-Sci Rev 31: 153-236.

Weijermars R, Roep TB, Van den Eeckhout B, Postma G, Kleverlaan K. 1985. Uplift history of a Betic fold nappe inferred from Neogene-Quaternary sedimentation and tectonics (in the Sierra Alhamilla and Almería, Sorbas and Tabernas Basins of the Betic Cordilleras, SE Spain). Geol en Mijnbouw 64: 397-411.

Westerhof AB. 1977. On the contact relations of high-temperature peridotites in the Serrania de Ronda, Southern Spain. Tectononophysics 39: 579-591.

Whitehouse MJ, Platt JP. 2003. Dating high-grade metamorphismconstraints from rare-earth elements in zircon and garnet. Contrib Miner Pet 145: 61-74.

Williams JR, Platt JP. 2018. A new structural and kinematic framework for the Alborán Domain (Betic-Rif arc, western Mediterranean orogenic system). Journal of the Geological Society. https://doi.org/10.1144/jgs2017-1086.

Wortel MJR, Spakman W. 2000. Subduction and slab detachment in the Mediterranean-Carpathian region. Science 290: 1910-1917.

Yamato P, Agard P, Burov E, Le Pourhiet L, Jolivet L, Tiberi C. 2007. Burial and exhumation in a subduction wedge: mutual constraints from thermomechanical modeling and natural P-T-t data (Sch. Lustrés, W. Alps). J Geophys Res 112: B07410. https://doi.org/ 07410.01029/02006JB004441.

Yamato P, Agard P, Goffé B, De Andrade V, Vidal O, Jolivet L. 2007. New, high precision P-T estimates for Oman blueschists: implications for obduction, nappe stacking and exhumation processes. J Metamorphic Geol 25: 657-682.

Zeck H, Monié P, Villa I, Hansen BT. 1990. Mantle diapirism in the W-Mediterranean and high rates of regional uplift, denudation and cooling. In: Symposium on Diapirism, Proceedings 2, pp. 403-422.

Zeck H, Whitehouse M. 2002. Repeated age resetting in zircons from Hercynian-Alpine polymetamorphic schists (Betic-Rif tectonic belt, S. Spain) — a U-Th-Pb ion microprobe study. Chem Geol 182: 275-292.

Zeck HP, Whitehouse MJ. 1999. Hercynian, Pan-African, Proterozoic and Archean Ion-Microprobe Zircon Ages for a Betic-Rif Core Complex, Alpine Belt, W Mediterranean - Consequences for Its PT-T Path. Contrib Mineral Petrol 134: 134-149.

Zeck HP, Williams IS. 2001. Hercynian metamorphism in nappe core complexes of the Alpine Betic-Rif belt, Western Mediterranean a SHRIMP zircon study. Journal of Petrology 42: 1373-1385.

Cite this article as: Bessière E, Jolivet L, Augier R, Scaillet S, Précigout J, Azañón J-M, Crespo-Blanc A, Masini E, Do Couto D. 2021. Lateral variations of pressure-temperature evolution in non-cylindrical orogens and 3-D subduction dynamics: the Betic-Rif Cordillera example, BSGF - Earth Sciences Bulletin 192: 8. 